\title{
RELAÇÃO ENTRE O GRAU DE SEVERIDADE E O SUCESSO DO TRATAMENTO SEM EXTRAÇÃO DA MÁ OCLUSÃO DE CLASSE II
}

\author{
FABRÍCIO PINELLI VALARELLI
}

Tese apresentada à Faculdade de Odontologia de Bauru da Universidade de São Paulo, como parte dos requisitos para obtenção do título de Doutor em Odontologia, área de Ortodontia.

(Edição Revisada) 



\section{RELAÇÃO ENTRE O GRAU DE SEVERIDADE E O SUCESSO DO TRATAMENTO SEM EXTRAÇÃO DA MÁ OCLUSÃO DE CLASSE ॥I}

\section{FABRÍCIO PINELLI VALARELLI}

Tese apresentada à Faculdade de Odontologia de Bauru da Universidade de São Paulo, como parte dos requisitos para obtenção do título de Doutor em Odontologia, área de Ortodontia.

\section{(Edição Revisada)}

Orientação: Prof. Dr. Guilherme Janson 


\begin{tabular}{|c|c|}
\hline & VALARELLI, Fabrício Pinelli \\
\hline V23r & $\begin{array}{l}\text { Relação entre o grau de severidade e o sucesso } \\
\text { do tratamento sem extração da má oclusão de } \\
\text { Classe II / Fabrício Pinelli Valarelli. -- Bauru, 2006. } \\
\text { 203p.: II.; } 30 \mathrm{~cm}+\text { apêndices }\end{array}$ \\
\hline & $\begin{array}{l}\text { Tese (Doutorado) - Faculdade Odontologia de } \\
\text { Bauru. Universidade de São Paulo. }\end{array}$ \\
\hline & Orientador: Prof. Dr. Guilherme Janson \\
\hline
\end{tabular}

Autorizo, exclusivamente para fins acadêmicos e científicos, a reprodução total ou parcial desta tese, por processos fotocopiadores e outros meios eletrônicos.

Assinatura do autor:

Data:

Projeto de pesquisa aprovado pelo comitê de ética em pesquisa da Faculdade de Odontologia de Bauru, Universidade de São Paulo, em 23 de junho de 2004. 


\section{Universidade de São Paulo Faculdade de Odontologia de Bauru}

Al. Dr. Octávio Pinheiro Brisolla, 9-75 - Bauru-SP - CEP 17012-101 - C.P. 73 PABX (OXX14)3235-8000 - FAX (0XX14)3223-7720

Pós-Graduação

e-mail: posgrad@fob.usp.br - Fone: (0XX14)3235-8223

\section{FOLHA DE APROVAÇÃO}

Tese apresentada e defendida por

FABRÍCIO PINELLI VALARELLI

e aprovada pela Comissão Julgadora

em 25 de julho de 2006.
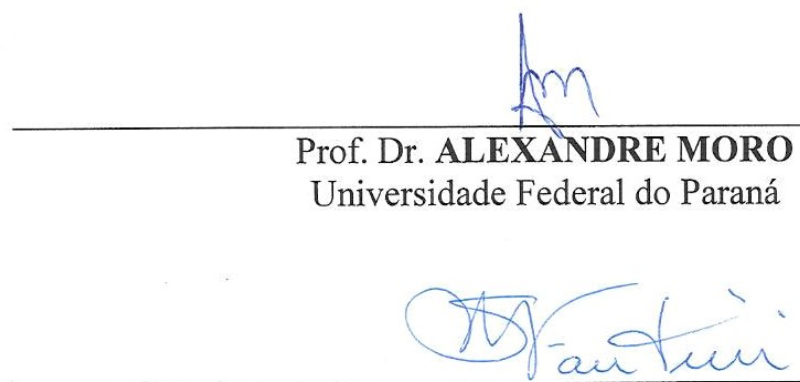

Prof. $^{\text {a }}$ Dr. ${ }^{a}$ SOLANGE MONGELLI DE FANTINI

Faculdade de Odontologia - USP

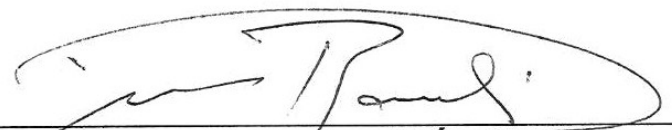

PrOf. Đr.DIRCEU BARNABE RAVELI

Faculdade de Odontolggia de Araraquara - UNESP

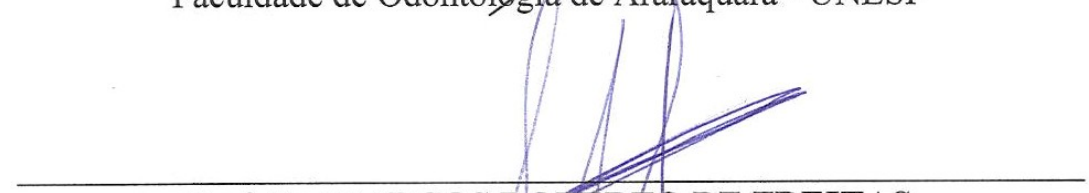

Prof. Dr. MARCOS ROBERTO DE FREITAS

Faculdade de esonto ogia de Bauru - USP

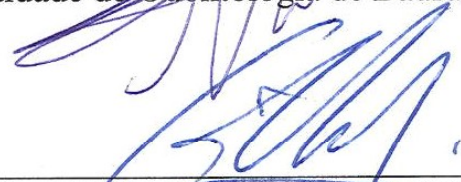

Prof. Dr. GUILHERME DOS REIS PEREIRA JANSON

Presidente da Banca e-Qrientador - FOB/USP

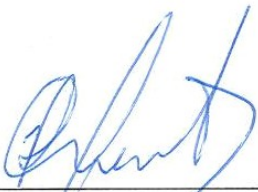

Prof. Dr. Paulo César Rodrigues Conti Vice-Presidente da CPG 



\section{DADOS CURRICULARES}

\section{FABRÍCIO PINELLI VALARELLI}

03 de março de 1975

Bauru - SP

$1994-1997$

$1998-2000$

$2000-2002$

$2003-2006$

Associações
Nascimento

Curso de Graduação em Odontologia pela Faculdade de Odontologia de Bauru - Universidade de São Paulo.

Curso de Aperfeiçoamento em Ortodontia na ACOPEN - Bauru - SP.

Curso de Pós-Graduação em ortodontia, ao nível de Mestrado, pela Faculdade de Odontologia de Bauru - Universidade de São Paulo.

Curso de Pós-Graduação em Ortodontia, ao nível de Doutorado, pela Faculdade de Odontologia de Bauru - Universidade de São Paulo.

Associação Paulista de CirurgiõesDentistas 

Denicatória 



\section{DEDICO ESTE TRABALHO}

A DEUS, por me conduzir, me iluminar e me dar força em mais uma etapa da minha vida, guiando os meus passos para que todos os obstáculos encontrados fossem superados.

Aos meus queridos pais, IVAN e ARLENE, que sempre estiveram ao meu lado me incentivando na busca do conhecimento, compreendendo meus ideais de vida, fazendo o possível e o impossível para o meu enriquecimento humano e profissional e acima de tudo me dando muito amor e carinho além de me proporcionar uma vida cheia de alegria e felicidade.

Ao amor da minha vida, THAIS, pelo amor, carinho, paciência, cumplicidade, compreensão, e por ser essa pessoa maravilhosa que tanto eu amo.

Obrigado por entender, sem cobranças, todos os momentos de ausência, em algumas vezes mesmo quando eu estava presente. Sua constante presença na minha vida foi fundamental para a realização deste trabalho. 



\section{AGRADECIMENTOS ESPECIAIS}

Ao Prof. Dr. Guilherme Janson, pelas experiências e conhecimentos transmitidos de maneira sábia e sincera, pelo exemplo de dedicação à carreira e à profissão, pelo rigor científico com que conduz seus trabalhos e clareza que expõe seus objetivos. Seus ensinamentos contribuíram sobremaneira para o meu enriquecimento cultural e científico.

Ao coordenador do curso de doutorado, professor, tio e amigo, Prof. Dr. José Fernando Castanha Henriques, por todos os conhecimentos transmitidos dentro e fora do curso de doutorado, por me incentivar à percorrer os caminhos da Ortodontia, sempre estando presente ao menor sinal de dúvida e me apoiando nas decisões mais difíceis.

Aos professores da disciplina de Ortodontia Dr. Décio Rodrigues Martins, Dr. Renato Rodrigues de Almeida, Dr. Marcos Roberto de Freitas e Dr. Arnaldo Pinzan, pela valiosa contribuição para a minha formação profissional e pela amizade proporcionada nos últimos anos. Pela atenção, paciência e seriedade na arte de ensinar, fazendo com que os nossos objetivos fossem alcançados de forma primorosa. 



\section{AGRADECIMENTOS}

Aos meus irmãos, Danilo e Liciane, pelo apoio e incentivo incondicional em todos os momentos da minha vida, e pelo grande amor e carinho demonstrados todos os dias.

A minha tia Arlete e primos, Rafael e esposa Paola, e Fernanda, pelo carinho e estímulos constantes e pela convivência agradável e muito enriquecedora.

Ao meu tio Ayres, tia Eliane (in memorian) e primas Aryane, Saryta e Rebecca por todos os bons momentos compartilhados e pela palavra amiga e de companheirismo sempre presentes.

Ao meu tio Ivaldo, tia Lana, e primos Thiago e Thalissa pelo incentivo, amizade e momentos de grande felicidade.

Ao Sr. José Marchini, $D^{\text {na }}$ Marilene, Karina e Thiago, pela amizade, carinho, incentivo durante os últimos anos e pela receptividade que encontrei em sua casa, mesmo quando eu não estava nos melhores dias.

À amiga e colega Claudinha, por seu trabalho incansável, por sua eficiência e por tomar conta do consultório nesse tempo de ausência.

Ao grande amigo Walter Lázaro Batista, pela palavra sábia e apoio incessante em todos os momentos.

Ao amigo José Eduardo Prado de Souza, pelos momentos compartilhados e por transmitir seus incontestáveis conhecimentos relacionados à prática Ortodôntica. 

Ao amigo Rodrigo Hermont Cançado, por compartilharmos alegrias juntos desde a graduação seguindo o caminho da carreira acadêmica e pela sua palavra sábia e sincera em todos os momentos.

À grande amiga e colega de profissão Juliana Curi pela palavra honesta e grande incentivo durante o doutorado.

Ao técnico de informática e colega Daniel Francisco Rascão Selmo, pelo tempo despendido na resolução dos problemas relacionados ao meu pouco conhecimento no campo da informática.

Aos grandes amigos, Luiz, Victor, Henrique, Murilo, João, Maninho, Celinho, Hiroshi, Marcão e Gustavo pela amizade e momentos agradáveis e descontraídos todos esses anos.

Aos funcionários do Departamento de Ortodontia Cris, Verinha, Sérgio, Boné, Danilo, "Tia" Maria, Luciana e Neide pela amizade e colaboração para o desfecho desse trabalho.

Ao pessoal da ACOPEN, Sônia, Cesão, Luciana e $D^{\text {na }}$ Délia pelo carinho e amizade com que sempre me tiveram.

Ao professor José Roberto Lauris, por todos os conhecimentos e explicações transmitidas em relação à realização da análise estatística desse trabalho.

Aos funcionários da SDO, Leia, Érica, Wagner, Émerson e funcionários do consultório, Paula, Érica, Fátima, pela ajuda doada em todos os momentos da realização desse trabalho. 

Aos funcionários da Biblioteca, pela atenção e serviços prestados.

Aos pacientes que muito contribuíram para o meu enriquecimento profissional.

A todas as pessoas que contribuíram direta ou indiretamente para a realização desse trabalho.

\section{Agradecimentos administrativos}

Ao Prof. Dr. Luiz Fernando Pegoraro, Diretor da Faculdade de Odontologia de Bauru - USP.

Ao Prof. Dr. José Carlos Pereira, Presidente da Comissão de Pós-Graduação da Faculdade de Odontologia de Bauru - USP.

À Fundação de Amparo à Pesquisa do Estado de São Paulo (FAPESP), pela concessão da bolsa de estudo durante o período de realização deste trabalho. 

Resumo 



\section{RESUMO}

O objetivo desse estudo foi avaliar a relação entre o grau de severidade da má oclusão de Classe II e o sucesso do tratamento sem extração desses pacientes. A amostra se constituiu de 277 pacientes que apresentavam inicialmente má oclusão de Classe II, de ambos os sexos, nas fases de dentadura mista tardia ou permanente que foram tratados ortodonticamente sem extração. Os pacientes foram divididos em 2 grupos. O grupo 1 constituído por pacientes que apresentavam má oclusão de 1/2 Classe II. O grupo 2 constituído por pacientes que apresentavam má oclusão de Classe II completa. Estes pacientes foram selecionados em caráter retrospectivo, verificando-se todo o arquivo da Disciplina de Ortodontia da Faculdade de Odontologia de Bauru - USP. O Índice de Prioridade de Tratamento (IPT) foi utilizado para verificar a severidade inicial da má oclusão assim como os resultados oclusais ao final do tratamento de cada paciente. As médias dos escores iniciais e finais do IPT foram comparadas entre os grupos pelo teste t não pareado. $\mathrm{O}$ índice de eficiência foi calculado pela proporção entre a porcentagem de melhora pelo tempo de duração do tratamento. Os resultados mostraram uma diferença significante entre os grupos. Houve maior proporção de sucesso do tratamento ortodôntico sem extrações da má oclusão de 1⁄2 Classe II em comparação à Classe II completa. O tempo do tratamento ortodôntico foi maior nos pacientes que apresentavam inicialmente ao tratamento, uma Classe II completa. O índice de

eficiência do tratamento foi maior em pacientes com menor severidade inicial da má oclusão de Classe II. 

Abstract 



\begin{abstract}
The purpose of this study was to evaluate the relationship between the degree of Class II malocclusion severity and the occlusal success rate of non-extraction treatment. Group 1 comprised dental study models of 144 patients with $1 / 2$ Class II malocclusion and Group 2 comprised dental study models of 133 patients with complete Class II malocclusion. Grainger's treatment priority index (TPI) was used to assess the initial and final occlusal status of each patient. The initial and final mean TPI of each group were compared with independent $t$ tests. The treatment efficiency degree was calculated as the ratio between the percentages of occlusal improvement, evaluated through the TPI, by the treatment time. The results showed a statistically significant difference of the groups. Non-extraction treatment of $1 / 2$ Class II malocclusion provides a better occlusal success rate than treatment of complete Class II malocclusion. The duration of complete Class II malocclusion nonextraction treatment was significantly greater than $1 / 2$ Class II malocclusion treatment extraction.
\end{abstract}





\section{LISTA DE FIGURAS}

Figura 1 - Má oclusão de $1 / 2$ Classe II.................................................... 107

Figura 2 - Má oclusão de Classe II completa.............................................. 109 



\section{LISTA DE TABELAS}

Tabela 1 - Médias, desvios padrão, mínimo e máximo das idades dos grupos experimentais no início do tratamento ortodôntico.......

Tabela 2 - Gênero, tipo de má oclusão, dentadura e total de pacientes dos grupos experimentais no início do tratamento ortodôntico.

Tabela 3 - Apresentação dos pesos que compõem o Índice de Prioridade de Tratamento (IPT)

Tabela $4-\quad$ Abreviaturas utilizadas no trabalho

Tabela 5 - Resultados do teste $t$ pareado e da fórmula de DAHLBERG, aplicados às variáveis IPTI; IPTF; para estimar os erros sistemáticos e casuais, respectivamente.

Tabela 6 - Resultados do teste Qui-Quadrado para avaliar a compatibilidade dos grupos 1 ( $1 / 2 \mathrm{Cl}$ II) e $2 \mathrm{~A}$ (Cl II completa) em relação ao gênero, tipo de Classe II e a quantidade de pacientes na fase de dentadura mista e permanente.

Tabela 7 - Resultados do teste $t$ independente, aplicado às variáveis IDADEI (idade inicial) e IPTI (IPT inicial) para os grupos $1(1 / 2$ Cl II) e $2 \mathrm{~A}$ (CI II completa)

Tabela 8 - Resultados do teste Qui-Quadrado entre as porcentagens de sucesso do tratamento ortodôntico entre os grupos 1 ( $1 / 2 \mathrm{Cl}$ II) e 2 (Cl II completa conjuntamente aos pacientes replanejados) 

Tabela 9 - Resultados do teste Qui-Quadrado entre as porcentagens de sucesso do tratamento ortodôntico entre os grupos $1(1 / 2 \mathrm{Cl} \mathrm{II})$ e 2A (Cl II completa) .......................................................... 127

Tabela 10 - Resultados do teste $t$ independente aplicado às variáveis estudadas nos grupos $1(1 / 2 \mathrm{Cl}$ II) e $2 \mathrm{~A}$ (Cl II completa)............ 



\section{SUMÁRIO}

$1 \quad$ INTRODUÇÃO

2 REVISÃO DE LITERATURA .......................................................... 41

2.1 CARACTERÍSTICAS DA MÁ OCLUSÃO DE CLASSE II........................ 43

$2.2 \quad$ FORMAS DE TRATAMENTO DA CLASSE II...................................... 53

2.2.1 Tratamento da Classe II com extrações............................................. 53

2.2.2 Tratamento da Classe II sem extrações............................................ 60

2.2.2.1 Tratamento com aparelhos ortopédicos funcionais................................. 64

2.2.2.2 Tratamento com ancoragem extrabucal associada aos aparelhos

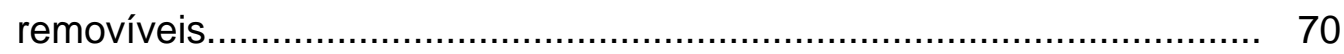

2.2.2.3 Tratamento em 1 fase $X$ tratamento em 2 fases................................... 75

2.3 COOPERAÇÃO EM ORTODONTIA............................................... 80

2.4 TEMPO DE TRATAMENTO............................................................... 84

2.5 SEVERIDADE DA CLASSE II................................................ 87

2.5.1 Severidade cefalométrica ..................................................... 88

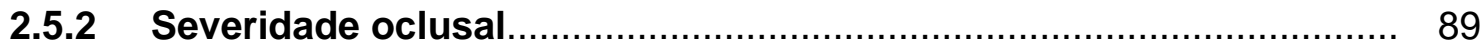

2.6 ÍNDICES DE AVALIAÇÃO OCLUSAL................................................. 92

$3 \quad$ PROPOSIÇÃO

$4 \quad$ MATERIAL E MÉTODOS ............................................................... 103

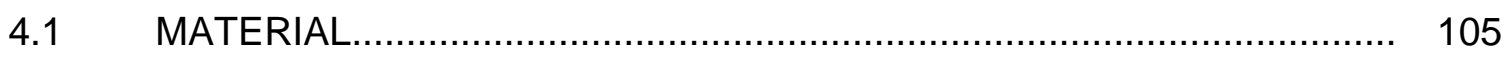

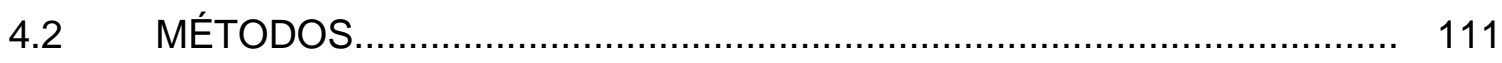

4.2.1 Documentação ortodôntica........................................................... 111

4.2.2 Análise dos modelos................................................................ 112

4.2.3 O Índice de Prioridade de Tratamento.............................................. 113

4.2.4 O índice de eficiência do tratamento (IET) ...................................... 117

4.2.5 Abreviaturas utilizadas para representar as variáveis

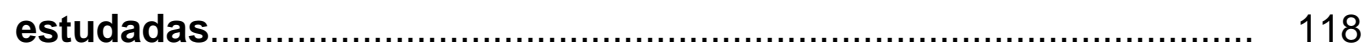

4.2.6 Análise Estatística.................................................................. 119

4.2.6.1 Erro do Método........................................................................ 119

4.2.6.2 Análise estatística entre grupos e variáveis......................................... 120 



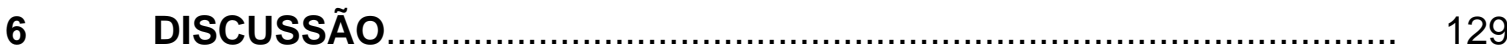

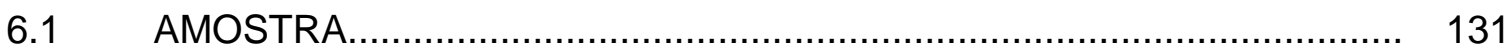

6.2 METODOLOGIA ................................................................... 135

6.3 PRECISÃO DA METODOLOGIA..................................................... 139

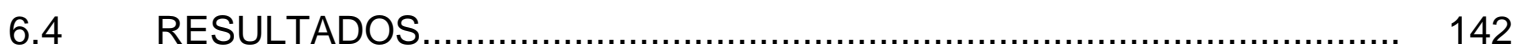

6.4.1 Compatibilidade entre os grupos.................................................... 142

6.4.1.1 Gênero.................................................................................... 142

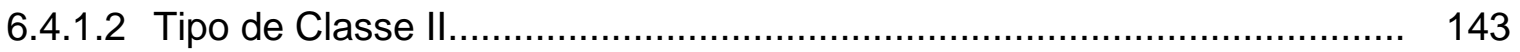

6.4.1.3 Fase da dentadura..................................................................... 143

6.4.1.4 Idade inicial................................................................................ 144

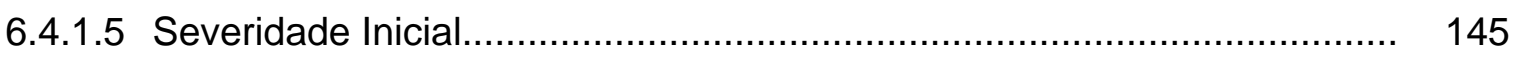

6.4.2 Resultados oclusais............................................................. 146

6.4.2.1 Proporção de sucesso do tratamento ortodôntico.................................... 146

6.4.2.2 Resultado oclusal final e proporção de melhora.................................... 147

6.4.3 Tempo de tratamento.......................................................... 150

6.4.4 A eficiência do tratamento ortodôntico.......................................... 152

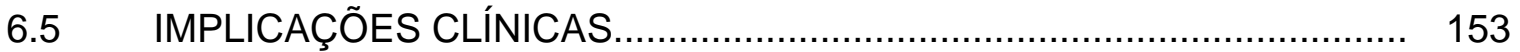

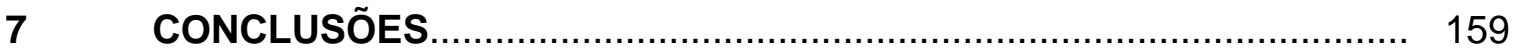

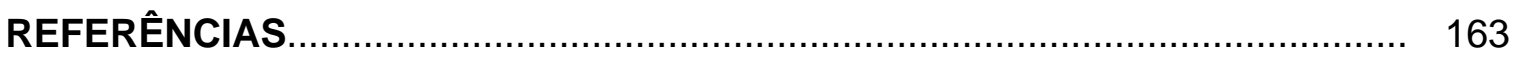

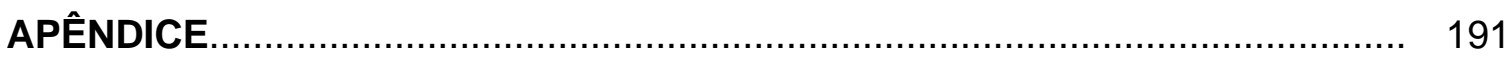



INTRODUÇÃo 



\section{INTRODUÇÃO}

As pesquisas ortodônticas têm tradicionalmente se preocupado com os efeitos do tratamento ortodôntico e não com a severidade das más oclusões e a eficiência dos métodos de tratamento ${ }^{292}$. Isto se aplica principalmente ao tratamento da má oclusão de Classe II. Diversos métodos de tratamento têm sido descritos $^{34,43,105,144,172,174,207,302}$, sem que suas eficiências tenham sido demonstradas. Para que um método de tratamento seja eficiente, não é apenas desejável que ele corrija a má oclusão, mas sim que essa correção seja realizada em um período de tempo razoável, com um menor desgaste do paciente e do profissional e com respeito à integridade biológica ${ }^{75}$. Além disso, o resultado obtido deverá ser excelente. Teoricamente, espera-se que quanto mais severa for a discrepância ântero-posterior da má oclusão de Classe II, e quanto maior a idade do paciente, menor será a probabilidade de correção dessa má oclusão, sem extração $^{129,150,278}$. Entretanto, não existem estudos que tenham demonstrado a eficiência dessa forma de tratamento, de acordo com esses dois parâmetros mencionados $^{150}$.

A melhor forma de realizar esse tipo de avaliação consiste em estudar retrospectivamente uma população significante de pacientes de Classe II, tratados com sucesso sem extração, e verificar suas severidades oclusais iniciais e as idades desses pacientes, com a intenção de fornecer prognósticos de sucesso de tratamento mais confiáveis para o clínico, no tratamento de seus pacientes. Isso irá proporcionar tratamentos mais eficientes, economizando tempo do profissional e principalmente do paciente. Se o tempo de tratamento é mais bem aproveitado, o 
custo para o paciente também diminui. Portanto, esse trabalho tem o objetivo de avaliar a proporção de sucesso do tratamento sem extração da má oclusão de Classe II de acordo com sua severidade inicial. 
$\mathbf{R}_{\text {eVISÃo de }}$

Literatura 



\section{REVISÃO DE LITERATURA}

\subsection{CARACTERÍSTICAS DA MÁ OCLUSÃO DE CLASSE II}

O primeiro relato científico sobre o diagnóstico e as características morfológicas das más oclusões foi realizado por $\operatorname{ANGLE}^{9}$ em 1899, ao publicar seu método de classificação. Baseava-se essencialmente nas posições dentárias. Considerava os primeiros molares superiores como referência e o relacionava com os primeiros molares inferiores no sentido ântero-posterior. Descreveu, portanto, a má oclusão de Classe II como sendo um posicionamento distal do primeiro molar inferior em relação ao primeiro molar superior. Essa classificação demonstrou-se muito prática descrevendo a má oclusão no sentido ântero-posterior, porém, além de não considerar as discrepâncias no sentido vertical e transversal, também não quantificava a magnitude da má oclusão. Mais tarde, em 1907, simplificou sua classificação, considerando os casos de Classe II como um posicionamento distal da mandíbula em relação à maxila, freqüentemente observada de tamanho menor ${ }^{10}$.

HELLMAN ${ }^{132}$, em 1922, realizou observações antropométricas e observou que a má oclusão de Classe II apresentava uma retroposição tanto da mandíbula quanto da maxila, na maior parte dos casos. Concordando com essa característica, em 1928 OPPENHEIM ${ }^{203}$ observou que na maioria das más oclusões de Classe II, ocorre uma falta de desenvolvimento mandibular. Em seu estudo comparou medidas antropométricas de 18 crânios com características normais e 18 exibindo má oclusão de Classe II. Concluiu que a Classe II não se caracterizava por um excesso de crescimento para anterior da maxila, verificado pelo ponto Próstio, mas 
que na grande maioria dos casos de distoclusão, este ponto encontra-se posicionado posteriormente.

Em 1946, ANDERSON ${ }^{7}$ afirma que muitas más oclusões são diagnosticadas somente pela relação dos molares. Entretanto em seu estudo, observou que muitos casos diagnosticados como más oclusões de Classe II não pertenciam, realmente, a essa categoria e que a Classe II é uma entidade muito mais complexa do que muitos autores haviam afirmado anteriormente. Afirmou que um diagnóstico pobre ou errôneo pode levar a procedimentos incorretos no seu tratamento.

A partir desses estudos, vários autores pesquisaram as características morfológicas envolvidas na composição da má oclusão de Classe II verificando as diversas alterações sagitais concernentes a essa má oclusão ${ }^{86,100,195,215,254}$. Observa-se que esta pode estar relacionada à presença isolada ou à combinação do prognatismo maxilar, do retrognatismo mandibular, com retrusão dos dentes inferiores e protrusão dos superiores, sendo o retrognatismo mandibular considerado como um dos maiores responsáveis por esta má oclusão ${ }^{243}$.

Com o objetivo de determinar as diferenças existentes entre os padrões esqueléticos faciais da Classe I e da Classe II, divisão 1, CRAIG ${ }^{70}$, em 1951, comparou um grupo de 34 pacientes Classe I com 12 anos de média de idade, com um grupo de 33 pacientes Classe II, divisão 1, com média de idade semelhante. Concluiu, por meio de sobreposições, utilizando um sistema gráfico de coordenadas, que ambos os grupos apresentaram um padrão esquelético similar, porém o grupo da Classe II, divisão 1 apresentou um menor corpo mandibular, verificado pela distância linear Go-Gn.

Para verificar a posição espacial da maxila e da mandíbula em relação à base do crânio nos diferentes tipos de má oclusão, RIEDEL ${ }^{235}$, em 1952, realizou uma 
pesquisa com telerradiografias. A amostra constituiu-se de 52 adultos com oclusões normais, na faixa etária dos 18 a 36 anos; 24 jovens com oclusões normais e idades de 7 aos 11 anos; 38 casos com Classe II, divisão 1, 10 casos com Classe II, divisão 2 e 9 com Classe III. Concluiu que as alterações mais significantes encontravam-se no posicionamento ântero-posterior da mandíbula, avaliado pelo ângulo SNB e na relação maxilomandibular, quando verificada pelo ângulo ANB. Nos casos de Classe II, divisão 1, a mandíbula apresentou-se mais retruída em comparação com o grupo de oclusão normal.

Com intenção de determinar os componentes da Classe II divisão 1 que indicassem uma proposta para sua correção, FISK ${ }^{100}$ em 1953, afirmou existirem seis possibilidades morfológicas para a má oclusão de Classe II. 1. base óssea maxilar e dentes superiores situados anteriormente em relação ao crânio; 2. dentes superiores posicionados anteriormente em relação à base óssea; 3. mandíbula subdesenvolvida; 4. mandíbula com tamanho normal, mas posicionada posteriormente; 5. dentes inferiores posicionados posteriormente em uma base apical adequada; 6. qualquer combinação dos fatores anteriores.

Com o objetivo de aprimorar a classificação das más oclusões SERVOSS ${ }^{254}$, em 1975, acrescentou quatro termos à classificação de Angle. Os termos prognatismo ou retrognatismo referem-se ao posicionamento anterior ou posterior, respectivamente, das bases ósseas em relação ao esqueleto craniofacial. Adicionalmente, os termos protrusão ou retrusão descrevem o posicionamento anterior e posterior dos dentes em relação às bases ósseas. Estas condições são distintas, porém podem apresentar-se combinadas. Concluiu que a Classe II, divisão 1, pode resultar de uma protrusão dos dentes superiores, um prognatismo 
maxilar, uma retrusão do arco dentário inferior, um retrognatismo mandibular ou mais freqüentemente, de uma combinação destes fatores.

PFEIFFER; GROBÉTY ${ }^{215}$, em 1975, afirmaram que a má oclusão de Classe II provém da combinação de alterações dentoesqueléticas, e que na maioria dos casos, a maxila apresenta-se bem posicionada e os incisivos superiores protruídos. Entretanto, a característica mais freqüentemente observada foi a retrusão da mandíbula com os incisivos inferiores bem posicionados. Os autores alertaram ainda para a importância de um correto diagnóstico diferencial para a Classe II, indicando os mais diversos aparelhos para a sua correção.

Após o estabelecimento dessas variabilidades morfológicas da má oclusão de Classe II, vários pesquisadores postularam a necessidade de uma observação que não se restringisse somente ao posicionamento ântero-posterior das bases ósseas $^{76,145,164,166,195,215,250,254,304}$. Nesse sentido, em 1970, SASSOUNI ${ }^{248}$ descreveu em seu trabalho os diversos tipos faciais envolvidos na má oclusão de Classe II, alertando para as variações esqueléticas da maxila e mandíbula no sentido vertical.

A classificação proposta por WOODSIDE ${ }^{304}$, em 1980, para definir a má oclusão de Classe II incluiu três tipos, dentoalveolar, esquelética e muscular, e foi dividida em 7 subtipos: 1) face harmoniosa com Classe II dentoesquelética; 2) protrusão do complexo nasofaríngeo e mandíbula bem posicionada; 3) complexo nasofaríngeo normal e mandíbula retruída; 4) complexo nasofaríngeo normal, mandíbula muito retruída e perfil facial bastante convexo; 5) complexo nasofaríngeo e maxila protruídos com mandíbula retruída; 6) relação maxilomandibular adequada com obstrução nasal ocasionando retrusão da mandíbula quando em repouso e 7) variação do subtipo 1 com espaço funcional livre muito aumentado. 
Em 1980, MOYERS et al $^{195}$, utilizaram uma combinação de programas computadorizados para descrever uma série de tipos de Classe II, com características verticais e horizontais bem definidas. Identificaram seis tipos horizontais: uma "Pseudo-classe II" ou Classe II dentária; quatro síndromes de Classe II esqueléticas graves; e um caso moderado de Classe II esquelética, com uma variedade de sintomas. Encontraram também cinco tipos verticais, o primeiro apresentava o plano mandibular acentuadamente inclinado para baixo; no segundo, os planos mandibular, oclusal e palatino encontravam-se quase paralelos entre si; o terceiro mostrava o plano palatino inclinado para cima; no quarto, os planos mandibular, oclusal e palatino apresentavam-se acentuadamente inclinados para baixo; e no quinto, os planos mandibular e oclusal denotavam normalidade, e o plano palatino encontrava-se inclinado para baixo. Por meio da marcante relação entre os dois padrões, vertical e horizontal, identificaram quinze subtipos com características bem definidas. Ressaltaram que os indivíduos de um mesmo tipo de Classe II, com uma aparência e um padrão de crescimento semelhante necessitavam de tratamentos similares e provavelmente deveriam responder da mesma forma.

Do mesmo modo, McNAMARA Jr. ${ }^{191}$, em 1981, observando que os tipos de tratamentos comumente utilizados para a correção da Classe II variam nos efeitos apresentados, procurou especificar os componentes contribuintes para a formação dessa má oclusão. Analisou duzentos e setenta e sete telerradiografias em norma lateral de indivíduos entre 8 e 10 anos de idade e observou quatro componentes horizontais e um vertical. Verificou que a Classe II pode ser resultado de uma combinação numerosa de componentes esqueléticos e dentários, sendo que somente uma pequena porcentagem exibia uma protrusão maxilar em relação à 
base do crânio, apresentando-se bem posicionada na maior parte dos casos, ou até mesmo, mais freqüentemente retruída do que protruída. Além disso, os pacientes apresentaram uma marcante variação no desenvolvimento vertical, e pelo menos em metade da amostra, observou-se um excessivo desenvolvimento vertical. Os incisivos superiores não apresentaram grande protrusão e os inferiores mostraramse bem posicionados na maior parte dos casos. A retrusão mandibular foi a característica mais comum.

Em 1985, ARVYSTAS ${ }^{14}$ comenta alguns fatores que contribuem para a composição de vários tipos de más oclusões de Classe II e que mecanismos ortodônticos deveriam ser utilizados de acordo com a necessidade específica de cada paciente. Conclui que para um correto tratamento e a finalização em uma oclusão funcional e uma face harmoniosa, os pacientes devem ser avaliados individualmente.

BUSCHANG et $a^{52}$ em 1986, compararam o crescimento exibido por jovens do sexo masculino com oclusão normal e com Classe II. Este trabalho longitudinal estudou cefalometricamente dos 11 aos 14 anos, 40 jovens, dos quais 20 com oclusão normal, 12 com má oclusão de Classe II divisão 1 e 8 com Classe II divisão 2. Os resultados mostraram poucas diferenças entre os jovens com oclusão normal e os portadores da má oclusão. As diferenças observadas foram descritas em: 1 . velocidade de crescimento da base do crânio maior nos pacientes Classe II divisão 1; 2.comprimento mandibular; e 3. ângulo ANB. Entretanto, os grupos exibiram similares incrementos de crescimento, indicando que as diferenças em tamanho são estabelecidas antes dos 11 anos de idade e mantidas durante a adolescência.

As alterações dentofaciais em jovens com más oclusões de Classe II divisão 1 não tratados foram pesquisadas por CARTER $^{57}$, em 1987. O autor avaliou 
estudos cefalométricos que compararam os valores médios para indivíduos com má oclusão de Classe II, divisão 1, com padrões cefalométricos normais. Concluiu que, nos jovens com Classe II, a maxila apresenta-se bem posicionada em relação à base do crânio e a mandíbula moderadamente retruída, e os incisivos superiores mostraram-se protruídos, quando comparados com amostras controle. O autor ressaltou ainda que o aumento médio nas dimensões lineares apresentou-se quase três vezes maior nos jovens do gênero masculino, comparado ao feminino. Não obstante tenha verificado uma considerável variação individual, houve uma maior tendência de redução do trespasse horizontal nos jovens do gênero masculino, não observado no gênero feminino.

Em 1994, KARLSEN ${ }^{157}$, procurou detectar as diferenças no posicionamento das bases ósseas entre jovens com má oclusão de Classe II e simultaneamente portadores de mordida aberta anterior e sobremordida profunda. Os resultados mostraram que ambos os grupos mostraram uma mandíbula retruída e de comprimento diminuído. A altura facial ântero-inferior e o ângulo do plano mandibular mostraram-se aumentados nos jovens com mordida aberta anterior, cuja mandíbula apresentou-se com o corpo menor. Verificando a falta de um padrão ideal para avaliação da má oclusão de Classe II no sentido ântero-posterior, em 1995, ROSENBLUM ${ }^{240}$ propôs um método para avaliar a relação entre maxila e mandíbula. Descreveu que as variáveis angulares que utilizam a linha SN são pobres e não mostram correlação com as demais.

BISHARA; CUMMINS; JAKOBSEN ${ }^{37}$, em 1995 ressaltaram em seu trabalho as características individuais da Classe II divisão 1. Indicaram que os portadores dessa má oclusão apresentam uma maior sobressaliência horizontal, sobremordida 
profunda, maior ângulo ANB, incisivos superiores protruídos, convexidade facial aumentada, lábios protruídos e mandíbula retruída.

Em 1996, ENLOW \& HANS ${ }^{94}$ concluíram que na maioria dos casos de má oclusão de Classe II ocorrem algumas situações como diminuição do comprimento do corpo mandibular, aumento no sentido vertical do complexo nasomaxilar, desenvolvimento vertical mais suave do arco dentário superior em relação ao inferior, porém mais acentuada nos incisivos quando comparadas aos molares, rotação mandibular para baixo e para trás, alinhamento para baixo e para frente da fossa craniana média, fechamento do ângulo goníaco, estreitamento no sentido horizontal do ramo mandibular e aumento no comprimento da fossa craniana média. Afirmam que essas características estão presentes em $70 \%$ dos casos avaliados.

A comparação das mudanças ocorridas nas estruturas dentofaciais de jovens com má oclusão de Classe II divisão1 e com oclusão normal foi realizada por BISHARA et al $^{40}$, em 1997, que avaliaram 65 jovens de ambos os gêneros em três estágios do desenvolvimento da oclusão: depois de completada a dentadura decídua (5,5 anos), após o final do irrompimento dos primeiros molares (8 anos) e após o estabelecimento completo da dentadura permanente (12 anos). Como a literatura apresenta este mesmo tipo de comparação de forma transversal e longitudinal os autores procederam das duas maneiras buscando melhor equivalência com outros resultados. Na comparação transversal foi relatada a diferença significante no comprimento mandibular durante os dois primeiros estágios, contudo ausente no estágio de dentadura permanente completa, indicando que o estirão de crescimento permitiu a eliminação da diferença. Para a comparação longitudinal os autores encontraram semelhança na tendência de crescimento entre a Classe II divisão 1 e a oclusão normal, porém a magnitude de 
crescimento apresentou-se desigual em um pequeno número de parâmetros. Os autores sugeriram que as comparações longitudinais oferecem maiores parâmetros para avaliar o padrão de crescimento desde que incluam jovens com relativa severidade de Classe II, divisão 1.

Na mesma linha de pesquisa do estudo anterior, BACCETTI et al. ${ }^{16}$, em 1997, utilizaram dois grupos que foram avaliados longitudinalmente ( 2 anos e 6 meses) desde a fase de dentadura decídua à dentadura mista. Os grupos constituíam-se de 25 jovens com má oclusão de Classe II e 22 jovens com oclusão "normal". Os autores observaram que a relação de Classe II apresentada inicialmente, se manteve ou se tornou ainda pior durante o período avaliado. O padrão esquelético da Classe II caracterizou-se pela retrusão mandibular significante, deficiência no comprimento efetivo da mandíbula e rotação deste no sentido horário. Por outro lado, a maxila apresentou crescimento para anterior significante. Concluíram que os sinais clínicos da má oclusão de Classe II são evidentes na dentadura decídua e persistem na dentadura mista.

A escassez de pesquisas abrangendo grupo controle motivou HENRIQUES et al. ${ }^{136}$, em 1998, a estudarem as características dentoesqueléticas da má oclusão de Classe II, divisão 1, em jovens não tratados ortodonticamente. A amostra foi constituída de 25 jovens com idade inicial de 9 anos e 4 meses, que foram acompanhados longitudinalmente por 3 anos e 4 meses. Os resultados demonstraram que em $75 \%$ dos casos a mandíbula apresentou-se retruída, enquanto a maxila variou entre retruída, bem posicionada e protruída. O padrão de crescimento denotou variabilidade, com distribuição uniforme de indivíduos com predominância de crescimento vertical, horizontal e equilibrado. A altura facial ântero-inferior aumentou em decorrência do crescimento facial. A relação 
maxilomandibular não mostrou melhora significante, mantendo a discrepância esquelética da má oclusão de Classe II. Em relação ao componente dentário, verificaram que os molares e incisivos superiores acompanharam o crescimento maxilar, apresentando mesialização e extrusão; enquanto os inferiores também extruíram, porém com a mesialização apenas dos molares e retrusão dos incisivos agravando o trespasse horizontal.

Em relação à posição ântero-posterior dos maxilares, GURGEL; ALMEIDA; PINZAN $^{125}$, em 2000, encontraram em seu trabalho que a posição mandibular foi a diferença mais evidente quando um grupo de Classe II divisão 1 foi comparado com um grupo controle de oclusão normal, quanto às dimensões das bases esqueléticas tanto horizontais quanto verticais. Ambos os grupos apresentavam idade média de 12 anos e 10 meses e eram compostos por dezenove e vinte e cinco anos respectivamente. O posicionamento da maxila foi similar nos dois grupos tanto no sentido horizontal como vertical, entretanto o grupo de má oclusão de Classe II divisão 1 apresentou em vários casos a presença tanto da protrusão, como da retrusão maxilar.

Destacando a importância da análise facial como exame auxiliar no diagnóstico e planejamento ortodôntico, em 2001, BRANDÃO; DOMINGUEZRODRÍGUEZ; CAPELOZZA FILHO ${ }^{46}$ avaliaram as características da má oclusão de Classe II, divisão 1, observadas nas telerradiografias e compararam com as características morfológicas da face, verificadas na análise facial subjetiva. A amostra constou de 30 jovens, de ambos os gêneros, com idades entre 12 e 16 anos. A análise cefalométrica mostrou perfil ósseo convexo, maxila bem posicionada e mandíbula retruída em relação à base do crânio, incisivos superiores e inferiores protruídos nas bases ósseas, trespasse horizontal acentuado e vertical 
moderado. O exame facial subjetivo mostrou um envolvimento da maxila em 3 casos (10\%); da mandíbula em 13 casos (43,3\%); associação da maxila e mandíbula em 43,3\% (13 casos) e maxila e mandíbula consideradas bem posicionadas em apenas 1 caso (3,3\%). Assim, concluíram que a avaliação subjetiva apresentou uma razoável coerência, comparada aos valores obtidos na análise cefalométrica.

\subsection{FORMAS DE TRATAMENTO DA CLASSE II}

O tratamento da má oclusão de Classe II tem sido um ponto muito polêmico na ortodontia contemporânea, em função da extensa variabilidade de estratégias de tratamento, destacando-se os aparelhos ortopédicos funcionais e o tratamento por meio de aparelhos fixos com ou sem extrações dentárias. Esses métodos de tratamento foram divididos em 2 tópicos, tratamento com e sem extrações, com o objetivo de simplificar o entendimento sobre o tema abordado neste trabalho.

\subsubsection{Tratamento da Classe II com extrações}

Contrariando o princípio não extracionista de Angle, $\mathrm{CASE}^{58}$, em 1908, admitia as extrações nos casos de protrusões acentuadas ou nas discrepâncias dentofaciais severas. Os principais casos de má oclusão de Classe II, divisão 1 que requerem extração, segundo $\operatorname{CASE}^{59,60}$ são: protrusão do lábio superior, com os dentes inferiores e a mandíbula bem posicionados e protrusão superior acompanhado de retrusão mandibular. Enfatiza ainda que a extração não deve estar relacionada com o apinhamento, e sim com a obtenção de um perfil facial harmônico. 
Após o surgimento da técnica de Edgewise, idealizada por ANGLE ${ }^{11,12}$, inúmeros autores apresentaram diferentes tipos de mecânica de acordo com a filosofia de tratamento preconizada. Como discípulo de Angle, TWEED ${ }^{281,282}$, ao aplicar os princípios básicos da técnica acima mencionada no tratamento das más oclusões de Classe II, divisão 1, sem extração, preocupava-se com os constantes fracassos clínicos obtidos. Para solucionar esse impasse, TWEED ${ }^{281,282}$, em 1936, passou a admitir a possibilidade das extrações dos primeiros pré-molares superiores e inferiores para obter melhor posicionamento dos dentes em suas inclinações axiais corretas, contrariando assim os princípios de seu mestre. Posteriormente, em $1941^{283,284}$, idealizou o preparo de ancoragem, que sem dúvida, aliado às extrações dentárias, alterava todo o sistema mecânico proposto inicialmente por ANGLE ${ }^{10}$.

Graças à sua genialidade, Tweed revolucionou a ortodontia, apresentando casos retratados com extrações dos primeiros pré-molares, provando indiscutivelmente a eficácia de sua mecânica, quando coadjuvada por um diagnóstico correto. A partir da década de 50, com o advento da cefalometria, TWEED ${ }^{285}$, passa a basear rotineiramente seu diagnóstico no triângulo de Tweed, alicerçado em valores normativos para os ângulos FMA, IMPA e FMIA, como guias diagnósticos para a posição axial dos incisivos inferiores dentro de suas bases ósseas e a partir daí indicar ou não a necessidade de extrações para correção cefalométrica 97,244 .

O plano de tratamento ortodôntico pode variar de acordo com as características dentárias, esqueléticas e faciais de cada paciente e da mecânica utilizada pelo profissional. Estudos realizados sobre a má oclusão de Classe II, revelam que as extrações dentárias devem constituir parte do tratamento ortodôntico quando essa má oclusão for considerada uma verdadeira biprotrusão ou 
casos em que se necessita da correção da relação ântero-posterior dos arcos dentários ${ }^{268}$.

MOORE ${ }^{194}$, em1959, defende que um conhecimento básico sobre o crescimento facial e a influência do gênero e da idade é fundamental para o crescimento e o planejamento da correção desta má-oclusão. Relata que as extrações dentárias devem sempre ser consideradas como uma alternativa, nos casos com espaços insuficientes para as necessidades de movimentação dentária, com complemento de aparelhos extrabucais tipo Kloehn ${ }^{170}$ para um redirecionamento do crescimento maxilar, mesmo que as extrações sejam inevitáveis.

Para autores como TULLEY; CAMPBELL ${ }^{275}$, em 1965, o apinhamento é uma das principais indicações para extrações no arco inferior em tratamentos de casos de Classe II, divisão 1. Eles afirmam que não é possível criar espaço com aparelhos para corrigir o apinhamento sem utilizar extrações no arco inferior. Caso os incisivos inferiores sofram vestibularização para obter espaço para o alinhamento dos pré-molares, esses dentes apresentarão uma tendência de recidiva por causa da ação contrária do lábio.

Porém, outros autores ${ }^{116,177,246,273}$ advertem que a protrusão dos incisivos inferiores devem servir de guia, mas não são aceitos como critério invariável para a extração de pré-molares inferiores. GRABER ${ }^{117}$, em 1969, relata que a remoção de quatro pré-molares na má oclusão de Classe II dificulta o controle da sobremordida. Segundo o autor, o controle da inclinação axial dos incisivos requer maior quantidade de torque potencializando a resposta iatrogênica do dente. Portanto, a extração de quatro pré-molares pode não ser a melhor escolha, ou melhor, a extração no arco inferior pode não ser aconselhável. Num estudo com 150 
pacientes com má oclusão de Classe II, divisão 1 , Graber notou que $2 / 3$ desse pacientes apresentavam, essencialmente, os arcos inferiores normais, tanto em relação à forma quanto em relação à posição dos dentes. O problema se mostrava na relação espacial do arco inferior com o arco superior.

Segundo TERRY ${ }^{273}$, em 1969, casos com um maior deslocamento para mesial dos dentes superiores e um bom perfil facial, exceto pelo posicionamento anterior do ponto $\mathrm{A}$, podem ser mais bem tratados com a remoção bilateral dos prémolares superiores. Geralmente os dentes escolhidos para serem extraídos são os primeiros pré-molares. Entretanto, as mensurações dos dentes freqüentemente indicam que a remoção do segundo pré-molar, por ser este menor que o primeiro, permitirá melhor intercuspidação reduzindo assim o problema de espaço ou diminuindo a tendência dos dentes ântero-inferiores sofrerem um leve apinhamento e promovendo melhor estética aos incisivos superiores.

LITT \& NIELSEN ${ }^{177}$, já em 1984, apresentava uma alternativa para a extração de quatro pré-molares naqueles casos em que provavelmente há uma insuficiência de crescimento ósseo. O autor discorria sobre a remoção dos dois primeiros prémolares superiores. Isso permitiria uma redução da protrusão da pré-maxila, a eliminação da sobressaliência excessiva, e possibilitaria o estabelecimento da atividade normal da musculatura peribucal. Além disso, os movimentos radiculares dos dentes em casos tratados com duas extrações são mais fáceis quando comparados aos casos de extrações de quatro pré-molares diminuindo também o tempo de tratamento. Os molares apresentariam, ao final do tratamento, uma relação de Classe II, devido às extrações realizadas somente no arco superior. Já para VADEN ${ }^{286}$, em 1991, os casos de Classe II, divisão 1 que apresentam biprotrusão e apinhamento provavelmente serão tratados com a extração dos quatro 
primeiros pré-molares, consequentemente dificultando a finalização em Classe I de molares.

Para tentar melhorar a estética em pacientes com perfil divergente, ou ao menos não piorá-la, LAMARQUE ${ }^{173}$, em 1995, diz que se deve evitar trabalhar nesses pacientes com a mecânica de Classe II e o preparo de ancoragem devido ausência de controle vertical. Em pacientes que apresentam o perfil divergente e na fase de crescimento, o preparo de ancoragem pode melhorar o crescimento alveolar vertical no arco mandibular. Quando esse fenômeno ocorre, uma compensação no crescimento condilar poderá manter o mesmo valor do ângulo FMA. O plano oclusal também poderá manter-se estável, mas a face do paciente pode parecer alongada como um resultado do tratamento ortodôntico. Quanto maior for a tendência de crescimento vertical do paciente maior será o crescimento alveolar vertical com o preparo de ancoragem. Esse padrão de extração é mais adequado para o movimento mesial dos dentes póstero-inferiores colocando a oclusão numa relação de Classe I mais rapidamente. Além disso, esse procedimento requer menor preparo de ancoragem ${ }^{173}$. Em alguns pacientes o movimento mesial do primeiro molar inferior não é suficiente para corrigir a relação molar de Classe II então, o elástico de Classe II com força leve é usado cuidadosamente. Para um paciente com esse problema, algum preparo de ancoragem no segundo molar pode ser requerido $^{173}$

Em 1995, BISHARA; CUMMINS; JAKOBSEN ${ }^{37}$ compararam as características dentofaciais no pré-tratamento de pessoas com má oclusão de Classe II, divisão 1 tratados com e sem extração. Segundo os autores, algumas dessas características podem ajudar a identificar quais parâmetros influenciam na decisão de extração. O grupo com extração dos quatro primeiros pré-molares 
apresentava maior discrepância dentária em ambos os arcos e os lábios superior e inferior dos homens e o lábio inferior das mulheres estavam significantemente mais protruídos. Esse resultado indica que, nesse grupo de pacientes, lábio protruído é uma das razões mais importantes para se optar pela extração.

Quando a decisão tende para a extração, há ainda que se decidir qual dente seria preferencial, de acordo com benefícios mecânicos que poderiam promover. Desta forma a escolha do dente a ser extraído deve ser cuidadosamente analisada $^{48,83,268}$. Esta análise deve ser guiada pelo grau de discrepâncias entre a massa dentária e a óssea, além da quantidade de espaço a ser fechado após o correto posicionamento dos incisivos inferiores. Em casos de apinhamento severo, a escolha é quase sempre por primeiros pré-molares, praticamente não havendo espaços remanescentes. Já em casos limítrofes, há freqüentemente uma maior demanda de espaço que o necessário, espaço este que deve ser fechado com mesialização do segmento posterior ${ }^{109,286,288}$. Por isso, a extração de segundos prémolares $^{76,137,266,267}$ aumentando a ancoragem anterior de 6 para 8 dentes, facilitaria este fechamento de espaços com uma mesialização mais favorável do segmento posterior, evitando-se uma retroinclinação exagerada ântero-inferior, além de favorecer a correção da chave molar, e até mesmo uma rotação anti-horária da mandíbula ${ }^{306}$.

Os autores STRANG ${ }^{268}$ e BRUSOLA ${ }^{48}$ concordam que o primeiro problema a ser resolvido nos casos de Classe II se refere à seleção dos dentes a serem extraídos, mas diferem quanto ao critério de seleção. A decisão, segundo STRANG ${ }^{268}$, depende dos seguintes fatores: 1. A gravidade da má oclusão: - se o caso de Classe II for uma biprotrusão, são extraídos geralmente os primeiros prémolares de ambos os arcos ou os primeiros pré-molares superiores e os segundos 
pré-molares inferiores; - se o caso de Classe II está agravado com um crescimento ósseo insuficiente, e os segmentos posteriores ocupam o espaço dos dentes anteriores, está indicada a extração dos primeiros pré-molares de ambos os arcos; 2. O crescimento dos maxilares: se a mandíbula cresceu o bastante para dar lugar a todos os dentes, mas a maxila apresenta apinhamento e rotações dentárias, pode ser aconselhável extrair os segundos molares superiores e utilizar o amplo espaço adquirido para a movimentação distal de todo o arco superior; 3. Idade do paciente: em pacientes com idade relativamente avançada, nos quais é conveniente encurtar ao máximo a duração do tratamento, e cujos dentes estão bem alinhados, as extrações se limitam aos primeiros pré-molares superiores.

Quando houver um grande apinhamento no arco inferior o tratamento deverá ser realizado com a remoção dos quatro primeiros pré-molares ou, dos primeiros pré-molares superiores e dos segundos pré-molares inferiores ${ }^{14,28}$. Porém, quando o paciente portador da má oclusão de Classe II não apresentar mais crescimento e possuir um arco inferior de tamanho normal, o tratamento poderá ser realizado com extrações dos primeiros pré-molares superiores ${ }^{45,116,168,180,251}$, o que resultaria na redução da sobressaliência excessiva e correção da chave de caninos, facilitando a extensão das movimentações mecânicas, finalizando o tratamento com os molares em Classe II. Outra forma de correção seria a distalização dos dentes superiores ${ }^{14}$.

JANSON et. al $^{150}$ em 2004, comparando o tratamento da Classe II completa com extração de dois e de quatro pré-molares, verificaram que o resultado oclusal é melhor com o protocolo com extrações de dois pré-molares, devido à maior facilidade de correção da relação ântero-posterior do segmento anterior.

No arco inferior, vários autores concordam que sempre que possível as extrações deveriam ser evitadas ${ }^{29,30,117,180}$. Uma opção para a correção do 
apinhamento inferior nestes casos seria o desgaste interproximal, ou stripping. Porém, enquanto este procedimento aumenta sua popularidade em casos exibindo um apinhamento anterior moderado, $\mathrm{ROCCO}^{238}$, em 1971, adverte que este procedimento deveria ser considerado apenas como um auxílio na eliminação de apinhamentos leves para a obtenção de um resultado mais estético, e não como uma alternativa primária para um adequado alinhamento dos dentes. Reforça ainda que a indicação mais pertinente se refira à presença de discrepâncias de tamanho dentário.

Os resultados atuais indicam que uma importante variável clínica que influencia a decisão pela extração é a presença de apinhamento ${ }^{28,104}$. Além disso, na má oclusão de Classe II, há outros parâmetros que podem ser observados. Porém, são mais subjetivos e incluem a inclinação dos incisivos, a filosofia de tratamento do profissional, os princípios biomecânicos praticados, o potencial de crescimento do paciente e a severidade das discrepâncias dentofaciais vertical, horizontal e ântero-posterior ${ }^{38}$.

\subsubsection{Tratamento da Classe II sem extrações}

A terapêutica selecionada para o tratamento ortodôntico dependerá, entre outros, da época de intervenção. Sendo esta realizada na fase da dentadura mista tardia, a relação de má oclusão de Classe II pode ser completamente corrigida sem a necessidade de extrações ${ }^{14,116}$. Os métodos clássicos para a correção da Classe

II sem extração requerem um significante grau de cooperação do paciente. Aparelhos distalizadores extrabucais e intrabucais, elásticos intermaxilares, 
aparelhos funcionais removíveis necessitam de grande cooperação do paciente para a obtenção do sucesso do tratamento ortodôntico ${ }^{226}$.

CASE $^{60}$, em 1964, descreve a má oclusão de Classe II, classificada por Angle, e afirma que esse meio de classificação dentária pode apresentar características faciais diferentes para cada paciente e conseqüentemente estabelecer planos de tratamento também diferentes. Baseado nesse fato, a extração de pré-molares não deve ser realizada em alguns pacientes com esse tipo de má oclusão. O autor conclui que esses casos de não extração estariam classificados por uma retrusão dos dentes inferiores em relação à um bom posicionamento mandibular (ângulo mento-labial aumentado) e com os dentes superiores bem posicionados ou levemente vestibularizados.

De acordo com SALZMANN ${ }^{246}$, em 1966, as extrações dentárias na terapia ortodôntica não devem ser utilizadas para abreviar o tratamento ou para alinhar dentes apinhados, mas como um método auxiliar de tratamento onde o arco basal não é grande o suficiente para acomodar todos os dentes sem provocar uma protrusão dentoalveolar, ou onde forças funcionais terão o potencial de causar uma recidiva. As extrações na terapia ortodôntica não são praticadas com base em porcentagens. Os dados cefalométricos que medem a protrusão dos incisivos inferiores com relação ao plano mandibular ou plano de Frankfort podem servir como guia, mas não são aceitas como critério invariável para a extração.

$\mathrm{Na}$ mesma época, GRABER ${ }^{116}$, apresenta um caso de Classe II tratado ortodonticamente onde demonstra que a interpretação cefalométrica não deve ser levada tão a risca. A aparente protrusão dos incisivos inferiores não justifica a extração no caso apresentado. O paciente apresentava uma possibilidade de crescimento horizontal da mandíbula e por isso o tratamento foi iniciado na fase de 
dentadura mista. Em outro caso tratado, também de Classe II, afirma que, em alguns casos o posicionamento mais anterior dos incisivos inferiores pode ser aceito.

JAKOBSSON $^{147}$, em 1967, descreveu o tratamento da Classe II em pacientes no período de dentadura mista realizado sem extrações dentárias. O autor utilizou o ativador e o aparelho extrabucal. Foram observados diversos efeitos das mecanoterapias empregadas como a redução do "overjet" e a restrição do desenvolvimento da maxila.

Para CLEALL \& BEGOLE ${ }^{66}$, em 1982, pacientes com má oclusão de Classe II, divisão 2 em fase de crescimento, na dentadura mista tardia ou no início da dentadura permanente são melhor tratados se a extração puder ser evitada. Essa opção de tratamento sem extração nos casos de má oclusão de Classe II, divisão 2 deve ser adotada sempre que possível pois, as características mais comumente associadas ao tratamento dessa má oclusão com protocolo de extração são a tendência acentuada de achatamento do perfil facial e aumento da sobremordida, ambas desfavoráveis para esse tipo de paciente ${ }^{177}$.

BELL; JACOBS; LEGAN ${ }^{30}$, em 1984, relatam que a extrusão ortodôntica de dentes posteriores em pacientes com padrão esquelético horizontal, com mordida profunda e associada à uma musculatura peribucal e mastigatória pesada, demanda tempo e dificuldade pois a mecânica extrusiva precisa trabalhar contra as forças oclusais. Além disso, a extração de pré-molares, geralmente associada à facilidade do tratamento ortodôntico em má oclusão de Classe II, nesse caso aumenta a complexidade do mesmo e aumenta o tempo de tratamento quando comparado à terapia sem extração.

Para $\mathrm{BASS}^{25}$, em 1983, a extração de dentes permanentes está contraindicada tanto para ajudar na correção oclusal quanto para aliviar o apinhamento. 
No trabalho de ARVYSTAS ${ }^{14}$, em 1985, a extração foi contra-indicada no tratamento da má oclusão de Classe II, divisão 1 de Angle. O autor apresentou um caso em que o paciente apresentava um perfil facial reto, sem nenhum apinhamento superior e com os incisivos superiores levemente retro-inclinados. A extração está contra-indicada em casos de má oclusão de Classe II, divisão 1, segundo ARVYSTAS ${ }^{14}$, quando ainda houver desenvolvimento dentário, crescimento alveolar, crescimento ântero-posterior da maxila e da mandíbula. Uma vez cessado o crescimento, uma opção de tratamento sem extração para esse tipo de má oclusão é a distalização dos dentes superiores.

Estudando os pacientes na fase adulta, ALEXANDER; SINCLAIR; GOATES ${ }^{4}$, em 1986, descrevem que a extração de pré-molares no arco inferior nesses pacientes deveria somente ser indicada depois de uma avaliação muito cuidadosa de todas as outras possíveis alternativas. São inúmeras as más conseqüências causadas pela extração de quatro pré-molares no paciente adulto. Em primeiro lugar é virtualmente impossível corrigir a má oclusão de Classe II com essa padronização de extração. Além disso, esse tipo de tratamento aumentaria a distância que os dentes teriam que movimentar, conseqüentemente aumentando o desconforto do paciente, o tempo de tratamento, o potencial de reabsorção radicular e a possibilidade de problemas periodontais ${ }^{117,177}$. Os problemas mecânicos resultantes de extrações inferiores são aumentados quando o paciente apresenta uma curva de Spee acentuada tornando extremamente difícil o seu nivelamento. Algumas alternativas poderiam ser viáveis para essa situação como, por exemplo, a redução de esmalte dos dentes e a expansão dos dentes posteriores, ou também a protrusão dos dentes anteriores ${ }^{4}$. 


\subsubsection{Tratamento com aparelhos ortopédicos funcionais}

Os aparelhos funcionais promovem a correção das discrepâncias esqueléticas no sentido ântero-posterior e transversal, contribuindo sobremaneira para uma melhora na relação das bases apicais e harmonia do perfil facial, além de diminuir sensivelmente as extrações dentárias. Ressalta-se que o tratamento com aparelhos ortopédicos deve ser indicado para jovens em fase de crescimento e desenvolvimento craniofacial, com a finalidade de alterar espacialmente a forma e o posicionamento das bases ósseas, redirecionando o crescimento da maxila e liberando o da mandíbula, gerando uma nova situação mais estável e equilibrada. Além disso, a ortopedia funcional dos maxilares tem o objetivo de modificar as estruturas dos tecidos moles pela fisioterapia, reeducando as funções motoras e o tônus muscular por meio dos exercícios, otimizando o desenvolvimento das estruturas bucofaciais e eliminando as alterações funcionais que possam interferir na evolução normal do desenvolvimento dentoesquelético.

Com a proposição de corrigir a discrepância entre as bases ósseas, proporcionando uma melhor condição estética a curto e longo prazo, a modificação do crescimento proporcionada pela utilização dos aparelhos funcionais tem constituído ao longo dos anos uma forma de tratamento de grande aceitação pelos ortodontistas na correção da má oclusão de Classe $\|^{25,62}$.

Em virtude da popularidade dos aparelhos funcionais e da diversidade de resultados dos estudos acerca dos efeitos por eles produzidos, WIESLANDER; LAGERSTRÖM $^{303}$, em 1979, desenvolveram um trabalho comparativo do tratamento das más oclusões de Classe II com um grupo não tratado, com a mesma má oclusão. Verificaram que a região dentoalveolar foi primariamente afetada. Os 
incisivos superiores apresentaram maior inclinação para lingual do que os controles e os inferiores, extrusão ligeiramente menor, o que contribuiu para a redução da sobremordida profunda. A influência no crescimento maxilar foi limitada, bem como no mandibular, não denotando diferenças estatisticamente significativas entre os grupos. Apesar disso, alguns casos apresentaram resultados bastante satisfatórios.

PFEIFFER ${ }^{213}$, em 1980, correlacionou o crescimento craniofacial com o ativador no tratamento da Classe II. Afirmou que o crescimento pode favorecer ou limitar o tratamento nos pacientes jovens, e que este nem sempre pode ser utilizado de maneira favorável ou na época adequada, em função de outros fatores. Considerou inapropriado postergar o início do tratamento ortodôntico até a época do surto máximo de crescimento craniofacial, devido: um decréscimo rápido da adaptação dos tecidos tegumentares neste período; a possibilidade do paciente apresentar problemas psicológicos, resultando na diminuição da cooperação do mesmo; maior possibilidade de extrações; a erupção dos segundos molares, dificultando a distalização dos primeiros molares; e o comprometimento da estabilidade à longo prazo em razão da menor adaptabilidade da musculatura bucofacial. Assim, concluiu que o tratamento com aparelhos ortopédicos, os quais os efeitos excedem o crescimento normal, deve ser iniciado em jovens do sexo feminino acerca dos 10 anos de idade e ser finalizado próximo aos 13 anos. Nos pacientes do sexo masculino, aos 11 anos e 6 meses, terminando aos 14 anos. Desta forma, inicia-se o tratamento ortopédico antes do surto de crescimento, finalizando-o um ano após o mesmo.

A crença de que a melhora no perfil e na estética facial proporcionada pelos aparelhos funcionais é superior àquela advinda do tratamento ortodôntico convencional (com aparelhos fixos) ${ }^{208}$, foi questionada por BARRER; GHAFARI ${ }^{20}$, 
em 1985, que avaliaram os resultados estéticos obtidos do tratamento ortodôntico realizado com aparelho de Fränkel, Beeg light-wire, straight-wire e edgewise, em uma amostra randomizada de pacientes apresentando má oclusão de Classe II, Divisão 1. Os autores concluíram que a estética facial avaliada a partir do contorno do perfil pré e pós-tratamento apresentou significativa melhora, porém, nenhuma das quatro modalidades de tratamento mostrou-se mais eficiente em produzir melhores perfis. Em 1989, BISHARA; ZIAJA ${ }^{34}$, compulsaram extensamente a literatura pertinente ao tratamento das más oclusões de Classe II, divisão 1, com os ativadores, os reguladores de função e os aparelhos fixos, segundo o mecanismo de ação, bem como a efetividade destes aparelhos. Após a pesquisa bibliográfica, ressaltaram que: 1- consideraram o aparelho funcional, apenas como uma das modalidades efetivas no tratamento da Classe II; 2- os casos de Classe II, divisão 1, ideais para a utilização de aparelhos funcionais, seriam aqueles em que os pacientes se encontrassem na fase de crescimento, os quais extrações dentárias prejudicariam a estética facial, com os incisivos superiores protruídos e inferiores retruídos, com trespasse vertical acentuado, e com uma inclinação do plano mandibular de média a plana e retrusão mandibular esquelética; 3- o sucesso do tratamento ortopédico depende da cooperação do paciente e da sua duração nos períodos de crescimento craniofacial; 4- os aparelhos ortopédicos devem ser utilizados por um período de tempo prolongado, geralmente de um ano e meio a dois anos, para assegurar uma completa adaptação condilar após o deslocamento inicial na cavidade glenóide; 5- a despeito do tipo de aparelho funcional utilizado, afirmaram que a correção da má oclusão ocorreria de maneira semelhante, ou seja, estimulando o crescimento mandibular, redirecionando o crescimento maxilar, inclinando os incisivos superiores para lingual, vestibularizando os incisivos 
inferiores, bem como promovendo uma erupção mesial e vertical dos molares inferiores e inibindo a erupção mesial dos molares superiores. A combinação dos efeitos dentoalveolares (60 a 70\%) e ortopédicos (30 a 40\%) permite a correção efetiva da má oclusão de Classe II. Além disso, a associação da tração alta extrabucal com os ativadores propicia um maior controle do crescimento vertical da maxila, melhorando consequentemente, o crescimento mandibular no sentido horizontal.

Inquirindo mais amplamente a crença sobre os efeitos diferenciados dos aparelhos funcionais na melhora do perfil, O’NEILL; HARKNESS; KNIGHT'202, em 2000, compararam a mudança na atratividade do perfil de pacientes portadores de má oclusão de Classe II, Divisão 1 tratados com o aparelho de Fränkel, ativador e não tratados. Os resultados mostraram que não houve diferença significante na atratividade do perfil entre os pacientes do gênero masculino ou feminino, tratados com ativador ou Fränkel. Além disso, não foi observada, também, qualquer alteração significante na atratividade do perfil entre o grupo de pacientes tratados e não tratados, concluindo que o tratamento com aparelhos funcionais não levou a um perfil mais atrativo em relação àquele não tratado.

A escassez de melhoras no perfil dos pacientes tratados ortopedicamente pode refletir a verdadeira extensão das tão proferidas mudanças esqueléticas atribuídas à utilização destes aparelhos. O fato de que os aparelhos ortopédicos promovem alterações esqueléticas nos maxilares que contribuem para a correção das más oclusões, sobretudo da má oclusão de Classe II, encontra-se bastante estabelecido e fundamentado na literatura vigente $19,25,54,81,96,129,209,225,294,295,302,305$. Contudo, as modificações no complexo côndilo-fossa, favoráveis à correção da má oclusão de Classe II e observadas por VOUDOURIS et al. ${ }^{295,296}$, PANCHERZ; 
FISCHER ${ }^{209}$, BALTROMEJUS; PANCHERZ ${ }^{19}$ e RABIE; SHE; HÄGG ${ }^{224}$, são válidas apenas enquanto o aparelho está sendo utilizado. Após o tratamento ortopédico, tanto as alterações qualitativas quanto as quantitativas, induzidas no crescimento, tendem a retornar aos parâmetros pré-tratamento.

As mudanças à longo prazo no comprimento mandibular foram também questionadas por DE VINCENZO ${ }^{81}$ que não observou qualquer impacto do tratamento ortopédico com aparelhos funcionais sobre o comprimento mandibular após 4 anos de observação. Embora o crescimento mandibular tivesse aumentado substancialmente durante o tratamento, a fase pós-tratamento foi marcada por uma proporção de crescimento mandibular inferior àquela observada no grupo controle. Resultados semelhantes foram reportados por WIESLANDER ${ }^{302}$, em 1993, quando avaliou os efeitos a longo prazo do aparelho de Herbst sobre o crescimento mandibular em pacientes portadores de má oclusão de Classe II severa. O autor observou que o significativo efeito protrusivo de $3,9 \mathrm{~mm}$ ocorrido durante a fase ativa de tratamento, reduziu para um valor não significante de $1,5 \mathrm{~mm}$ no período póscontenção, igualando-se ao grupo controle composto por pacientes portadores de má oclusão de Classe II, não tratados.

PANCHERZ; FISCHER ${ }^{209}$, em 2003, relataram que o período pós-tratamento foi acompanhado por uma menor quantidade de crescimento e por um retorno à direção de crescimento condilar mais vertical, semelhante àquela presente no período pré-tratamento. O remodelamento da fossa, que no período de tratamento foi redirecionado para anterior, retornou à direção posterior no período póstratamento. A reversão dos efeitos do tratamento foi também observada por VOUDOURIS; KUFTINEC ${ }^{294}$, em 2000. Na analogia feita pelos autores, a remodelação do côndilo e da fossa sob a ação dos aparelhos funcionais assemelha- 
se a uma lâmpada num reostato. A transdução dos estímulos mecânicos gerados pelos aparelhos funcionais ao côndilo e à fossa articular intensifica a remodelação óssea que ocorre nesta região. Contudo, uma vez removido o estímulo mecânico ao final do tratamento, a remodelação vai diminuindo em intensidade, até atingir um nível basal. Além disso, os autores afirmaram que o retorno do côndilo à fossa e a restituição da função muscular ao final do tratamento, sobretudo do digástrico anterior, gera um maior nível de compressão nesta região, determinando um alto grau de recidiva das mudanças ${ }^{296}$. Sendo assim, o restrito tempo de tratamento associado à recidiva pós-tratamento faz com que nenhuma quantidade clinicamente significante de tecido ósseo adicional esteja presente à longo prazo.

A literatura tem mostrado que o aumento do crescimento mandibular, produzido pelos aparelhos funcionais tende a não se perpetuar com o evolver do tempo, assemelhando-se aos efeitos produzidos por outras modalidades de tratamento para a Classe II que não incluem estes aparelhos $^{71,81,114,130,156,209,296,302,303}$. Algum efeito restritivo no crescimento maxilar resultante, principalmente, da utilização do AEB (aparelho extrabucal) associado ou não aos aparelhos funcionais e fixos, tem se somado à correção da má oclusão de Classe II, compensando parte da recidiva mandibular ${ }^{302}$, muito embora BERNSTEIN; ULBRICH; GIANELLY ${ }^{31}$ e GIANELLY; VALENTINI ${ }^{113}$ demonstraram por meio de um estudo cefalométrico, utilizando-se implantes metálicos, que a principal alteração maxilar decorrente do uso do AEB foi de ordem dentoalveolar.

A falta de evidências científicas referentes à perpetuação dos efeitos ortopédicos gerados pelo aparelho extrabucal, aparelho de Herbst e ativador foi a principal conclusão da extensa revisão de literatura realizada por AELBERS; DERMAUT ${ }^{2,80}$, em 1996. Considerando que: (1) as alterações dentoalveolares 
resultantes do tratamento ortopédico são proporcionalmente maiores ${ }^{34,84,130}$ (2) a menor proporção de alterações esqueléticas advindas do tratamento ortopédico tende a não se perpetuar ${ }^{81,127,130,209,296,302}$ e (3) o tratamento ortodôntico com aparelhos fixos são também acompanhados de alterações esqueléticas ${ }^{90,156,179,229}$ pode-se especular que estas duas modalidades terapêuticas não se diferem significativamente quanto às mudanças estruturais ao final do tratamento, como de fato concluíram EDWARDS ${ }^{90}$ e GIANELLY; ARENA; BERNSTEIN ${ }^{114}$.

2.2.2.2 Tratamento com ancoragem extrabucal associada aos aparelhos removíveis

A ancoragem extrabucal é frequentemente utilizada para o tratamento da má oclusão de Classe II visando conter ortopedicamente o desenvolvimento da maxila e do complexo dentoalveolar. Neste tipo de abordagem, a força aplicada limita-se a dois dentes de ancoragem e à resistência dos seus tecidos de suporte. De acordo com SEÇKIN; SURUCU ${ }^{253}$, aumentar a força nesta situação significa causar efeitos deletérios nos molares e produzir movimentos indesejáveis. Se a força ortopédica for dirigida contra a dentadura inteira, diminuirá o potencial de inclinação extrusiva dos molares superiores, como visto com o arco facial convencional ${ }^{115}$. Desta forma, quando existir uma superfície maior de dispersão, o nível da força pode ser aumentado e se obter maiores efeitos ortopédicos com mínimos efeitos ortodônticos.

Com esse propósito, muitos autores passaram, então, a descrever aparelhos removíveis associados à tração extrabucal, no intuito de obter um meio de distribuir melhor as forças por todo o complexo maxilar e alcançar um resultado ortopédico mais efetivo e controlado. PFEIFFER; GROBÉTY ${ }^{214}$, em 1972, fizeram uso da associação entre ancoragem extrabucal e aparelhos ortopédicos funcionais. Os 
autores enumeraram diversas vantagens de ambos os aparelhos, justificando a sua utilização conjunta: o ativador previne, intercepta e, se necessário, corrige hábitos perniciosos; atua como um mantenedor de espaço; expande, se preciso for; inicia a correção de posicionamento individual de dentes; inicia a correção da sobremordida profunda e ajuda a corrigir o relacionamento basal de classe II reorientando as forças fisiológicas; promove, por meio dos músculos de retração mandibular, o movimento mesial dos dentes inferiores e distal dos superiores e ainda especularam a inibição do crescimento da maxila.

Mesmo em uma época de grande popularidade, questionamentos surgiam sobre a real efetividade dos aparelhos funcionais no complexo facial. A opinião mais comum referia-se ao consenso de que os aparelhos disponíveis não eram capazes de promover um crescimento mandibular maior do que o geneticamente determinado.

Em 1987, GRABER; NEUMANN ${ }^{115}$ descreveram aparelhos ortodônticos fixos e removíveis combinados preconizados por vários autores, entre eles, o ativador combinado à tração extrabucal. Ponderaram que nos padrões verticais, os aparelhos funcionais provavelmente produzirão sucesso limitado e seqüelas indesejáveis, como a inclinação vestibular dos incisivos inferiores, altura facial anterior excessiva e estética facial empobrecida. O objetivo dos autores era responder duas questões sobre o tratamento com o Ativador combinado à ancoragem extrabucal: Qual o estímulo ou inibição do crescimento que se pode obter com esses aparelhos? e se essa modalidade de tratamento pode ser utilizada em padrões verticais de crescimento?

KIGELE $^{162}$, em 1987, concluiu que o tratamento combinado aparentou ser mais vantajoso que o tratamento com o Ativador apenas, especialmente para as 
classes II com padrão vertical de crescimento, devido à inibição exercida nessa direção.

A utilização do Ativador combinado com a ancoragem extrabucal tem sido recomendada para reduzir o deslocamento maxilar nos sentidos vertical e horizontal e aumentar o avanço mandibular. Com o objetivo de examinar as contribuições dos dentes e bases ósseas no tratamento da má oclusão de classe II, divisão 1 com essa terapia, LAGERSTRÖM et $\mathrm{al}^{172}$, em 1990, apresentaram resultados cujos valores cefalométricos, avaliados na telerradiografia em norma lateral, evidenciaram que os molares inferiores deslocaram-se para mesial em proporções similares ao avanço mandibular e do pogônio, sugerindo que o posicionamento da base óssea inferior é importante para o restabelecimento da oclusão normal, confirmada pelo pequeno movimento dos molares superiores em direção distal. Os incisivos superiores, bem como, paradoxalmente, os inferiores, moveram-se para uma posição mais verticalizada e a maxila apresentou uma direção de crescimento para trás.

Uma vez que o objetivo do tratamento combinado do Ativador com a ancoragem extrabucal é controlar a inclinação dentoalveolar e o crescimento ânteroposterior das bases ósseas para alcançar equilíbrio e harmonia faciais, HEATH ${ }^{131}$, em 1991, considerou que podemos concentrar nossas diretrizes de diagnóstico no ângulo nasolabial como critério final. Pela avaliação correta desse ângulo e iniciando a terapia apropriada em tempo adequado, julgou válido esperar que as modificações dentárias e esqueléticas fossem sinérgicas em vez de antagonistas. Finalizou enumerando as vantagens do emprego precoce do Ativador associado à ancoragem extrabucal com aumento dos benefícios terapêuticos pela manipulação do crescimento da mandíbula, controle vertical e horizontal da maxila e seus dentes, 
necessidade mínima de tração intermaxilar e permissão desses efeitos para um crescimento subseqüente em um ambiente funcional mais harmônico, para proveito do perfil facial.

A utilização somente do aparelho funcional para a correção da má oclusão de Classe II esquelética, na ótica de YOKOTA; MURAKAMI; SHIMIZU²07, em 1993, não é suficiente. Acreditam que a restrição do crescimento para anterior da maxila ou dos dentes superiores deva ser promovido simultaneamente com a estimulação do avanço mandibular, ou seja, para a obtenção de resultados mais significativos há a necessidade de se aplicar a força extrabucal associada aos aparelhos funcionais. Concluíram que, com esse método combinado, o relacionamento esquelético e oclusal, bem como o perfil facial podem ser modificados e corrigidos de modo que uma classe II esquelética assuma uma relação das estruturas faciais e oclusão normais, diminuindo o número de extrações realizadas na ortodontia.

As características básicas do Ativador conjugado ao aparelho extrabucal, preconizado pela disciplina de ortodontia da Faculdade de Odontologia de Bauru, foram apresentadas por HENRIQUES; FREITAS; SCAVONE JÚNIOR ${ }^{135}$, em 1993. Em virtude da grande controvérsia que cerca os conhecimentos sobre os efeitos da ortopedia funcional na estrutura óssea mandibular e devido à grande difusão na utilização de aparelhos combinados, como o ativador conjugado à ancoragem extrabucal, HENRIQUES ${ }^{133}$, em 1993, utilizou três tipos de ancoragem extrabucal (cervical, conjugada ao aparelho removível e combinada com o ativador) no tratamento de jovens com idade média de 10 anos. Concluiu que o crescimento mandibular no tratamento com o ativador combinado com a ancoragem extrabucal é expressivo, sem alterar o padrão de crescimento, promovendo a retificação do perfil, apesar de o ângulo nasolabial não refletir esse resultado. A restrição do crescimento 
maxilar foi constatada nos três grupos. Os incisivos superiores foram verticalizados, os molares superiores, distalizados, enquanto os dentes inferiores não foram influenciados pelo tratamento.

Alguns estudos recomendam a associação da tração extrabucal com o ativador alegando trazer, dessa forma, vantagens no controle do crescimento vertical da maxila, além do horizontal, o que seria extremamente benéfico nos casos de pacientes com divergência dos planos faciais. A fim de verificar as diferenças do tratamento com o Ativador apenas e do combinado à ancoragem extrabucal, ÖZTÜRK; TANKUTER ${ }^{205}$, em 1994, observaram a redução do deslocamento anterior do ponto A com ambos os tratamentos, embora tenha sido mais evidente nos pacientes que utilizaram a ancoragem extrabucal. O posicionamento tanto do ponto B como do gnátio foi estatisticamente mais anterior com os aparelhos do que sem e, comprovaram que o padrão de crescimento rotacional da face não é afetado por nenhuma das terapias. Não obstante, o aparelho Ativador combinado com a tração extrabucal revelou cefalometricamente, um comportamento de maior controle vertical, ainda que não significante.

Os resultados das alterações cefalométricas decorrentes do tratamento com o ativador combinado ao aparelho extrabucal foram publicados por HENRIQUES et al. ${ }^{134}$, em 1997. A pesquisa avaliou um grupo de vinte e cinco pacientes com idade média de 11 anos, tratado por um período médio de 1 ano e 2 meses. O aparelho empregado promoveu uma restrição do crescimento anterior da maxila e um aumento significativo da protrusão mandibular e das dimensões do ramo e corpo mandibular. Houve uma melhora da relação ântero-posterior maxilomandibular e do perfil esquelético, sem, no entanto, alterar o padrão de crescimento. Os incisivos superiores foram inclinados para lingual e resultaram numa retração evidente do 
lábio superior. Esse resultado gerou um aumento do ângulo nasolabial. Os incisivos inferiores tiveram sua inclinação controlada. Essa característica foi atribuída ao recobrimento desses dentes com o acrílico.

\subsubsection{Tratamento em 1 fase $X$ tratamento em 2 fases}

Embora as características morfológicas da má oclusão de Classe II comecem a se delinear num estágio bastante precoce do desenvolvimento ${ }^{16,169}$, a melhor época para o tratamento desta má oclusão permanece como uma questão clínica de grande controvérsia na literatura. Segundo PROFFIT; TULLOCH ${ }^{220}$, em 2002, o âmago do debate não consiste em provar que a má oclusão de Classe II pode ser corrigida em vários estágios do desenvolvimento, pois existem evidências clínicas suficientes de que isto é geralmente possível. Para os autores, a principal questão a ser esclarecida é se o tratamento precoce da Classe II, quase sempre sucedido por uma segunda fase de tratamento, pode surtir melhores resultados que o tratamento convencional, realizado em uma única fase, na dentadura permanente.

O protocolo de tratamento em duas fases preconiza o início do tratamento durante a pré-adolescência e dentadura mista com a utilização dos aparelhos ortopédicos funcionais e uma segunda fase na adolescência, após a erupção dos dentes permanentes, em que o tratamento é complementado com aparelhos fixos $^{88,184,249}$. O protocolo de tratamento em uma fase consiste na realização do tratamento ortodôntico com aparelhagem fixa em uma idade mais avançada, uma vez que o paciente deverá apresentar todos os dentes permanentes irrompidos na cavidade bucal. De acordo com este protocolo, a fase ortopédica com aparelhos 
funcionais é eliminada uma vez que a melhoria do padrão esquelético do paciente também é conseguida sem a utilização dos aparelhos ortopédicos funcionais ${ }^{188,227}$.

A maioria dos pacientes que exibe uma relação oclusal de Classe II de moderada a severa, apresentam concomitantemente, algum tipo de discrepância esquelética, advinda, principalmente, de uma deficiência mandibular ${ }^{158,191,220}$. Sendo assim, a abordagem precoce teria como objetivo a modificação do crescimento, além de reduzir significativamente a necessidade de extrações dentárias, tornando o tratamento subseqüente com aparelhos fixos, restrito ao alinhamento dos dentes e refinamento da oclusão ${ }^{25,307}$. Porém, esta argumentação, segundo PROFFIT; TULLOCH ${ }^{220}$ suscita três importantes questões: (1) o crescimento pode realmente ser modificado? e se pode, quais são os limites e a previsibilidade?; (2) diferentes aparelhos podem realmente produzir diferentes efeitos terapêuticos?; (3) qual o impacto que a intervenção precoce teria sobre o tratamento ortodôntico subseqüente? A segunda fase do tratamento seria realmente mais simples, rápida e com melhores resultados?

Considerando estas questões, BASS ${ }^{25}$, em 1983, e vários outros autores constantes na literatura ${ }^{119,176,239,307}$, concluíram que os principais benefícios provenientes da correção da má oclusão de Classe II são alcançados na fase ortopédica do tratamento e compreendem: (1) coordenação do crescimento maxilomandibular $25,176,239,307$; (2) melhor estética facial subseqüente ao tratamento, e na fase adulta $25,176,239$; (3) equilíbrio precoce da musculatura orofacial; (4) garantia de melhor estabilidade da correção em casos mais severos ${ }^{25,119}$; (5) diminuição do percentual de pacientes que necessitam de correção ortodôntico-cirúrgica ${ }^{25,239}$; (6) redução no risco de fraturas e avulsões dos incisivos superiores ${ }^{25,119,239}$; (7) menor dependência do crescimento crânio-facial para o sucesso da terapia corretiva, 
podendo ser iniciada na época mais oportuna para o paciente ${ }^{25}$; (8) alteração imediata da relação sagital pelo aparelho, motivando a cooperação do paciente durante a fase ortopédica e mantendo esta motivação na fase de correção com os aparelhos fixos $^{25}$; (9) redução significativa da necessidade de extrações de dentes permanentes para a correção da sobressaliência $25,119,239,307 ;$ (10) menor quantidade de movimentação dentária na fase corretiva ${ }^{25} ;(11)$ redução do tempo de tratamento com aparelhos fixos, diminuindo seus efeitos indesejáveis ${ }^{119,239,307} ;$ (12) melhora na auto-estima do paciente ${ }^{176,181}$.

GIANELLY ${ }^{112}$, em 1995, afirmou que pelo menos $90 \%$ dos jovens com más oclusões de Classe II poderiam ser adequadamente tratados em única fase com a utilização de aparelhos fixos, caso o tratamento se iniciasse no final do segundo período transitório da dentadura mista. Segundo o autor, nesta fase, a distalização dos molares superiores com aparelhos extrabucais e o crescimento mandibular favorecem a obtenção de uma relação molar normal em aproximadamente 4 a 6 meses com pouco esforço do profissional e do paciente. O autor concluiu que um maior custo e tempo de tratamento do protocolo em duas fases não implicam necessariamente em maiores benefícios para aqueles pacientes que são tratados com esse protocolo de tratamento.

Comparando o tratamento da Classe II em uma e duas fases, LIVIERATOS; JOHNSTON Jr. ${ }^{179}$, também em 1995, realizaram um estudo retrospectivo em 53 pacientes, sendo que 25 foram tratados em duas fases (Bionator/Edgewise) e 28 em uma única fase com aparelhos da técnica Edgewise convencional. Em ambos os grupos, os pacientes foram tratados sem extração. Os autores verificaram que as alterações esqueléticas nos dois grupos foram praticamente idênticas e que naqueles pacientes que foram tratados em duas fases, o tratamento se iniciou antes 
e terminou depois do que aqueles tratados em apenas uma fase. Os autores concluíram que o tratamento com aparelhos funcionais não promove benefícios biológicos aos pacientes.

VIG; VIG ${ }^{291}$ consideram que a escolha por um determinado protocolo terapêutico é geralmente baseada em critérios subjetivos e por isso propuseram um método para ajudar o clínico a optar pelo tratamento da má oclusão de Classe II, divisão 1 em uma ou duas fases. De acordo com o modelo proposto pelos autores, o tratamento em uma fase apresenta uma maior probabilidade de oferecer maiores benefícios aos pacientes.

Ainda em 1998, TULLOCH; PHILLIPS; PROFFIT ${ }^{276}$ realizaram um estudo prospectivo randomizado em 166 pacientes, na fase de dentadura mista, com sobressaliência maior ou igual a $7 \mathrm{~mm}$ que foram selecionados para tratamento com o aparelho extrabucal ou o Bionator por um período de 15 meses. Alguns pacientes foram apenas observados durante este período e compuseram um grupo controle. Dos 166 pacientes iniciais, 147 realizaram uma segunda fase do tratamento com aparelhos fixos, sendo que os resultados de 107 deles foram relatados neste artigo. Os autores verificaram que durante a fase 1, não houve, em média, alteração na relação maxilomandibular dos pacientes do grupo controle, no entanto em $5 \%$ deles houve uma melhora e em 15\% uma piora desta relação maxilomandibular. Em ambos os grupos que foram tratados precocemente, houve uma redução média significativa do ângulo ANB, sendo que no grupo tratado com o extrabucal ocorreu uma maior alteração nas dimensões da maxila, ao passo que no grupo tratado com o aparelho funcional, a melhora da relação maxilomandibular foi atribuída ao crescimento mandibular. Os resultados preliminares deste estudo mostraram que, em média, o tempo de tratamento com aparelhos fixos foi menor naqueles pacientes 
que receberam tratamento ortopédico quando comparados aos que foram tratados em apenas uma fase, no entanto o tempo de tratamento é consideravelmente maior se o tratamento precoce for considerado. O resultado oclusal entre os grupos foi semelhante quando avaliado por meio do índice PAR. E, finalmente, o número de pacientes que realizaram extração de dentes permanentes foi maior no grupo tratado com aparelho funcional do que no grupo tratado com o extrabucal. Alguns anos mais tarde, em 2004, TULLOCH; PROFFIT; PHILLIPS ${ }^{277}$ publicaram os resultados finais deste estudo randomizado. Os autores verificaram que, as diferenças que se criaram entre os pacientes do grupo controle e os pacientes que receberam tratamento precoce desaparecem quando todos foram tratados com aparelhos fixos na adolescência. Isto sugere que o tratamento em duas fases não é clinicamente mais efetivo do que o tratamento em uma fase. Além disso, não houve uma redução do tempo médio de tratamento com aparelhos fixos no grupo tratado em duas fases e nem mesmo da proporção de casos que necessitaram tratamentos mais complexos envolvendo extrações ou cirurgia ortognática.

Após realizarem uma análise criteriosa de três estudos prospectivos randomizados existentes na literatura ${ }^{110,159,276}$, KLUEMPER; BEEMAN; HICKS ${ }^{171}$ concluíram que ambos os protocolos de tratamento (uma fase e duas fases) são efetivos na correção das más oclusões de Classe II. Esta correção é obtida devido às alterações de natureza esquelética e dentária que ocorrem e estão na dependência da modalidade de tratamento instituída. Os estudos avaliados não suportam a premissa de que alterações favoráveis no padrão esquelético de crescimento somente podem ser obtidas em um tratamento realizado em duas fases. $\mathrm{Na}$ realidade, os estudos mais recentes mostram que o mais importante é que o tratamento da Classe II seja realizado quando o paciente estiver em crescimento e 
que a época em que se inicia o tratamento parece não influenciar o sucesso do tratamento da Classe II $^{155,156,179}$. Os autores concluíram que a época de se iniciar o tratamento da Classe II deve ser uma decisão conjunta entre o profissional, o paciente e seus familiares.

\subsection{COOPERAÇÃO EM ORTODONTIA}

Ao enumerar fatores que considera imprescindíveis para uma boa finalização de um tratamento ortodôntico, SALZMANN ${ }^{244}$, em 1963, destaca a importância da formação do ortodontista em conhecimentos de crescimento e desenvolvimento, etiologia, diagnóstico e obviamente informações e habilidade suficientes para tratar estas más oclusões. Considera que quando insucessos acontecem, nem sempre o ortodontista ou o aparelho utilizado pode ser o culpado. Para o autor, falhas podem ocorrer devido à natureza da má oclusão e da má formação dentofacial, e ainda freqüentemente, por falta de cooperação por parte dos pacientes em seguir corretamente as instruções do ortodontista.

O nível de motivação mantida pelo paciente no decorrer do tratamento parece ser uma variável cuja flutuação afeta consideravelmente a duração e a qualidade do tratamento ortodôntico. Baseado em anos de experiências, GABRIEL ${ }^{108}$, em 1968, especifica as características relacionadas à motivação que acredita serem fundamentais. Entre elas, tem-se a aceitação em relação aos procedimentos ortodônticos, higiene bucal, regularidade nas consultas, além de persistência, quantidade e correção no uso do aparelho extrabucal. Os seus achados evidenciam conclusivamente que quando o ortodontista planeja um programa de motivação de acordo com uma comunicação baseada no entendimento de cada paciente, a 
qualidade final pode ser consideravelmente aumentada e a duração do tratamento diminuída.

Algumas técnicas ortodônticas dependem da cooperação dos pacientes mais que outras, como dispositivos removíveis ${ }^{230,231}$, porém todas tendem a falhar sem sua presença. Além disso, enquanto o ortodontista é exaustivamente treinado em mecanoterapia, relativamente pouca atenção é dispensada à motivação do paciente. Antecipando-se a esta preocupação, GRABER ${ }^{118}$, em 1971, faz algumas considerações de fundamentação psicológica para esta abordagem. Considera serem de grande importância a personalidade do ortodontista, o comportamento psico-social dos pacientes, o impacto da equipe clínica, o ambiente clinico, além da grande participação da família durante o tratamento. Acredita que o ortodontista deve ir além do aparelho, procurando entender a criança, conhecer algo de seu meio ambiente e cotidiano, além de tentar um maior contato com seus pais. Para ele, a motivação é muito mais importante que qualquer aparelho, e por isso, delicadeza, empatia, firmeza e atenção devem ser empregadas para que a criança crie uma imagem positiva e de motivação em relação ao tratamento.

Muitas especulações são feitas sobre o perfil de um paciente cooperador ${ }^{5,264}$, quais o fatores que teriam influência sobre seu comportamento, como mensurar através de testes psicológicos ${ }^{68,72,91,93,197,261,270}$ estas tendências , e a partir daí, como conseguir predizer o nível de motivação e dedicação a se esperar. ALLAN; HODGSON $^{5}$, consideraram que o perfil de um paciente cooperador incluiria quase sempre qualidades como ser amigável, entusiástico, responsável, confiável, trabalhador, franco e atencioso. Os pacientes não cooperadores se enquadrariam em características como, dominadores, muito inteligentes, cabeças-duras, 
independentes, desinteressados, temperamentais, impacientes, individualistas, autosuficientes e intolerantes.

Para SLAKTER et al. ${ }^{261}$, é possível mensurar precocemente o nível de cooperação dos pacientes através de perguntas sobre o comportamento dos pacientes ( OPCS - Orthodontic Patient Cooperation Scale), e os resultados obtidos em suas investigações demonstraram-se estáveis, ou seja, pacientes cooperadores aos 2 meses de tratamento, tendem a continuar cooperadores aos 6 meses, agindo os não cooperadores da mesma forma. Também a partir do uso de testes de performance psicológica, CUCALON; SMITH ${ }^{72}$, em 1990, constataram que os pacientes adolescentes do gênero feminino demonstraram uma maior cooperação. Além disso, esta característica esteve associada a pacientes com maiores escores de auto-estima, satisfação, que apresentavam-se otimistas em relação ao futuro, tinham condições sócio-econômicas mais altas, além de demonstrarem um baixo grau de alienação da sociedade.

Como a falta de cooperação dos pacientes pode acarretar tempos de tratamento muito maiores que os estimados inicialmente, MACHEN ${ }^{183}$, em 1995, alega que esta questão deve ser cuidadosamente abordada pelo ortodontista desde o início do tratamento, por meio da inclusão no contrato inicial relativo ao tratamento, de uma cláusula específica que defina as regras que serão seguidas caso o tempo de tratamento extrapole o prazo inicialmente acordado, principalmente pela atitude não cooperadora do paciente. Normas sobre a extensão dos honorários, ou remoção dos aparelhos, devem estar expressas, para que sejam evitados desacordos com os pais. Alerta que todo e qualquer indício de não cooperação deve ser registrado desde o início, além de comunicado oficialmente aos pais, para que haja validade legal em qualquer litígio. 
Reconhecendo a grande dependência de cooperação no uso de aparelhos extrabucais, além da deficiência de métodos psicológicos para que seja alcançado um maior engajamento e motivação no uso destes dispositivos, NORTHCUTT ${ }^{200}$, nos anos 70, propôs a utilização de um "timer" acoplado à tala do aparelho extrabucal para um monitoramento mais preciso de sua utilização. Este relógio eletrônico em miniatura seria sensibilizado simultaneamente por 2 dispositivos separados: um baseado em corrente elétrica e outro baseado em pressão contra o pescoço, sendo que a tração isolada da tala não teria nenhum efeito. Segundo o autor, além de um monitoramento mais adequado, principalmente dos casos de cooperação inadequada, o que poderia levar imediatamente a uma mudança de planejamento, este controle eletrônico seria um fator complementar de reforço positivo na motivação dos pacientes que também acompanhariam mais de perto a quantidade de uso dos extrabucais e seus efeitos.

Devido a grande dificuldade de se monitorar o verdadeiro número de horas de uso de determinados aparelhos removíveis, SAHM; BARTSCH; WITT ${ }^{242}$, em 1990, propuseram o uso de um dispositivo micro-eletrônico com um sensor magnético acoplado a um aparelho funcional tipo Bionator, para a identificação exata da cooperação destes pacientes. Os resultados demonstraram que o tempo médio de uso diário foi de 7,65 horas por dia, enquanto a média do número de horas solicitadas aos pacientes foi de 14,9 horas, determinando um índice de cooperação de $50,59 \%$, o que significa dizer que os pacientes usaram seus aparelhos apenas a metade do tempo que os foi solicitado. Consideraram ainda como bastante frustrante a baixa correlação entre o número verdadeiro de horas utilizadas, e o julgamento que os operadores faziam através dos questionários, do número de horas que acreditavam estar sendo usados. 


\subsection{TEMPO DE TRATAMENTO}

A grande heterogeneidade de protocolos de tratamento que se seguem ao diagnóstico torna bastante difícil o estabelecimento de generalizações sobre procedimentos de tratamento e seus efeitos. Uma possível inter-relação entre a severidade inicial da má oclusão, a falta de cooperação do paciente e o tempo do tratamento ortodôntico sempre levantou muitas especulações e controvérsias. Para investigar esta suspeita, GREWE ${ }^{123}$, em 1972, examinou 66 casos tratados ortodonticamente, com idades entre 11 e 15 anos, que foram classificados quanto a sua severidade por índices de má oclusão, entre eles o IPT ${ }^{121}$ (Índice de Prioridade de Tratamento). Além disso, o grau de cooperação e a duração do tratamento foram determinados. Em seu trabalho, nenhuma correlação estatisticamente significante foi observada entre estas variáveis, assim como em outras investigações ${ }^{77,124,257}$, contrário aos achados de FINK; SMITH ${ }^{99}$ que verificaram valores maiores do ANB e do índice de severidade de Salzmann para pacientes que apresentaram maior tempo de tratamento, enquanto que o aumento no ângulo do plano mandibular diminuiu o tempo de tratamento em quase 0,3 meses para cada grau.

Outro fator, atualmente relatado, capaz de prolongar o tratamento, é a realização de extrações dentárias ${ }^{63,99,142,201}$. Com relação ao protocolo de extrações ou não, VIG et al. ${ }^{292}$, em 1990, dispuseram-se a avaliar se existia um relacionamento entre a freqüência de extrações e a duração do tratamento. A amostra utilizada apresentou freqüência média de 54\%, com grande variação de 25 a $84 \%$. O tempo de tratamento parece ter sido influenciado pelo número de arcos tratados, pelo número de fases e pela execução ou não de extrações. Quando os casos com e sem extrações foram comparados isoladamente em cada clínica, os casos sem 
extrações apresentaram uma menor duração de tratamento, redução esta que variou de 2,3 a 7,4 meses, dependendo da clínica em questão, resultados semelhantes aos de VADEN; KISER ${ }^{287}$.

A maioria dos pacientes ortodônticos se preocupa com o tempo que deverão usar os aparelhos fixos. Por isso, uma confiável estimativa do tempo de tratamento seria valiosa, inclusive para um gerenciamento clínico mais eficiente. Com este intuito, FINK; SMITH ${ }^{99}$, em 1992, avaliaram 118 pacientes, tratados por 6 clinicas diferentes. Destes casos, $38 \%$ se submeteram a extrações e $32 \%$ usaram aparelhos extrabucais. A média do tempo de tratamento para a amostra total foi de 23,1 meses, sendo que a mais importante variável relacionada a diferenças de duração de tratamento entre os casos foi a extração de pré-molares. O grupo sem extrações apresentou média de 21,95 meses, o grupo com extrações superiores teve média de 25 meses, e o grupo com extrações de quatro pré-molares apresentaram média de 26,18 meses. Este resultado demonstrou que para cada pré-molar extraído acrescentou-se 0,9 meses na duração do tratamento. Após o número de extrações, a variável de maior correlação em relação ao tempo de tratamento foi o número de consultas perdidas, refletindo de certo modo uma forma de não cooperação.

Partindo de uma amostra de 100 pacientes tratados ortodonticamente, DE SATURNO $^{77}$, em 1994, procurou estabelecer possíveis influências da severidade inicial dos casos, da adoção ou não de extrações no tratamento, e ainda estudar a possível influência sócio-econômica e cultural dos pacientes com a duração do tratamento ortodôntico. Dentre os casos tratados com extrações, $64 \%$ foram submetidos a extrações de quatro pré-molares e 18\% tiveram extrações de dois prémolares superiores isoladamente. O tempo médio de tratamento para o grupo sem extrações foi de 22,59 meses, enquanto o grupo com quatro extrações levou em 
média 27,07 meses. O grupo com somente duas extrações apresentou um valor médio intermediário de 25,28 meses. Concluem que os casos sem extrações foram 4,5 meses em média mais rápidos que os casos com quatro extrações e que a duração do tratamento apresentou uma maior correlação com a conduta do paciente (por exemplo, a sua regularidade às consultas) do que com a decisão de realizar extrações ou não.

Por outro lado, as más oclusões mais severas com uma acentuada discrepância ântero-posterior, têm-se relacionado à necessidade de extrações dentárias $^{142}$. Em conformidade com HOLMAN et al. ${ }^{142}$, O'BRIEN et al. ${ }^{201}$, em 1995, constataram em um estudo com 250 casos tratados ortodonticamente, com ou sem extrações, apresentando uma sobressaliência mínima de $5 \mathrm{~mm}$, uma associação positiva muito importante entre a duração do tratamento, com a severidade inicial, extrações e número de fases, embora ressaltem que aqueles pacientes submetidos a extrações apresentavam índices de má-oclusão mais severos. Por fim sugerem que os resultados finais e a quantidade de melhora não tiveram relação com o método terapêutico escolhido. Outro autor, GRACIANO ${ }^{120}$, em 2003, também constatou que más oclusões de Classe II tratadas com extrações apresentam um maior grau de discrepância ântero-posterior. No entanto, a necessidade de correção da relação ântero-posterior está relacionada como um maior tempo de tratamento ${ }^{120,237,290}$.

Um outro fator capaz de alterar o tempo do tratamento ortodôntico é o replanejamento do tratamento ${ }^{185,258}$. Segundo MARIA ${ }^{185}$, um elevado percentual de pacientes que iniciam o tratamento da Classe II sem extrações tem seu tratamento replanejado devido à tentativa mal sucedida de se corrigir a má oclusão de Classe II 
sem extrações. O período de tempo despendido nesta tentativa aumenta significantemente o tempo do tratamento.

A idade do paciente ao início do tratamento foi relatada por SHIA ${ }^{258}$ como um fator potencialmente capaz de influenciar o tempo do tratamento. Segundo o autor, pacientes cujo tratamento é iniciado numa fase muito precoce tendem a apresentar um maior tempo de tratamento. Além disso, vários autores já demonstraram que o tratamento da má oclusão de Classe II, quando realizado em mais de uma fase, aumenta significantemente o tempo de tratamento $29,179,201,220,292$. Por outro lado, o tratamento de pacientes adultos pode apresentar graus de dificuldade maiores, o que também prolonga o tratamento ${ }^{258}$. O grau de colaboração do paciente não afeta apenas os resultados, mas também o tempo de tratamento. Segundo CHEW; SANDHAM $^{63}$ e FINK; SMITH ${ }^{99}$, pacientes que faltam às consultas e quebram freqüentemente os aparelhos tendem a apresentar outras formas de não colaboração com o tratamento como, por exemplo, a falta de colaboração no uso de elásticos intermaxilares, AEB e quaisquer outros aparelhos removíveis.

\subsection{SEVERIDADE DA CLASSE II}

O preciso diagnóstico da Classe II implica em uma detalhada exposição das diferentes características (cefalométricas e oclusais) envolvidas com a má oclusão e é de extrema importância no tipo de mecânica e plano de tratamento a ser instituído para sua correção ${ }^{40,147,172,191,195,247,248,310}$. Atualmente, diversos autores têm comentado sobre a correlação entre características iniciais da má oclusão e a efetividade do tratamento ortodôntico ${ }^{61,102,163,201,206,278,300,310}$. Esse tópico será dividido em: severidade cefalométrica e severidade oclusal. 


\subsubsection{Severidade cefalométrica}

Com os estudos cefalométricos, que só tornaram-se possíveis com o advento do cefalostato por BROADBENT ${ }^{47}$ nos Estados Unidos e HOFRATH ${ }^{141}$ na Alemanha em 1931, permitindo a obtenção de telerradiografias padronizadas, constatou-se que as diferentes características de amostras avaliadas por vários autores apontam para a existência de diversas formas de má oclusão de classe II e com diferentes severidades na sua composição, observando-se os valores encontrados mediante a análise cefalométrica empregada ${ }^{18,94,136,191,217,243,247,248,293,304}$.

Em 1994, MUSICH ${ }^{196}$ sugeriu que o grau da severidade da deficiência mandibular, observada em muitos pacientes com má oclusão de Classe II, e o ângulo do plano mandibular poderiam ser considerados como fatores relacionados ao sucesso do tratamento ortodôntico.

TULLOCH et al ${ }^{278}$, em 1997, avaliaram o grau de alteração da severidade da má oclusão de Classe II por padrões cefalométricos. A variável escolhida foi o ângulo ANB, que segundo os autores representa a discrepância existente entre a mandíbula e a maxila. Os pacientes tratados com tração extrabucal apresentaram uma restrição do desenvolvimento anterior da maxila, enquanto os pacientes tratados com o bionator apresentaram maior desenvolvimento da mandíbula. Segundo os autores esses efeitos estão relacionados com a diminuição da severidade da Classe II.

Em 2000, KIM et al ${ }^{163}$ objetivaram estudar se algumas características cefalométricas verificadas no início do tratamento poderiam predizer os resultados da sua correção. Concluíram que as variáveis cefalométricas são mais valiosas como uma ferramenta de diagnóstico que uma ferramenta de prognóstico de 
tratamento, pois muitos casos considerados bem finalizados apresentavam medidas cefalométricas discordantes com os padrões de normalidade.

$\mathrm{PAE}^{206}$, em 2001, utilizaram as telerradiografias em norma lateral para avaliarem a severidade da má oclusão ao início do tratamento ortodôntico. Foi concluído que as telerradiografias, quando utilizadas juntamente com modelos de gesso, mostram um certa correlação na determinação da severidade de alguns tipos de más oclusões.

ZENTNER; PEYLO; BROTHAG ${ }^{310}$, em 2003 analisou por meio de telerradiografias em norma lateral e modelos de gesso o índice de sucesso por meio da correção oclusal de 96 pacientes. Concluiu que os parâmetros cefalométricos anteriormente ao tratamento ortodôntico são insignificantes como indicadores do sucesso da correção da má oclusão e a largura óssea da base apical apresenta-se como meio mais eficiente para avaliar o prognóstico do tratamento.

\subsubsection{Severidade oclusal}

Atualmente, sabe-se que o plano de tratamento ortodôntico não deve ser baseado em valores numéricos dos pacientes ${ }^{116,241,246}$, ou seja, baseado somente na análise cefalometrica dos casos que serão tratados. Em conseqüência disso, alguns estudos buscam parâmetros para caracterizar tanto cefalométrica como morfologicamente, no que diz respeito ao posicionamento dentário, os pacientes ao início do tratamento ortodôntico. Esses estudos têm o objetivo de identificar e predizer características individuais, ao início do tratamento, que possam ser referenciadas como pré-requisito ao sucesso do tratamento ortodôntico $50,163,276,300,310$. 
Em 1969, GRABER ${ }^{116}$, apresentou um caso de Classe II tratado ortodonticamente onde demonstra que a interpretação cefalométrica não deve ser levada tão a risca. A aparente protrusão dos incisivos inferiores não justifica a extração no caso apresentado. O ortodontista necessita lançar mão de outros meios de diagnóstico para a elaboração da melhor conduta de tratamento para o paciente. Neste contexto é cabível especular que simultaneamente à delimitação do problema esquelético, um aspecto de grande importância é a discrepância dentária ânteroposterior da má oclusão. Diante do exposto, a severidade do relacionamento ântero-posterior entre os molares torna-se um fator extremamente relevante para o sucesso do tratamento da Classe $11^{300}$.

Para ALEXANDER; SINCLAIR; GOATES ${ }^{4}$, em 1986, os procedimentos de extrações no tratamento ortodôntico geram uma maior dificuldade para correção da Classe II, um maior tempo de tratamento, um maior potencial de reabsorção radicular, além da possibilidade de problemas periodontais. Dentre as alternativas mecânicas consideradas estão os desgastes interproximais, a expansão dos arcos, além da projeção dos dentes anteriores, apesar de uma maior tendência de recidiva destas abordagens. Consideram ainda que o tipo de tratamento é dependente do grau de severidade inicial da má-oclusão.

O'BRIAN et $a^{201}$ em 1995 realizaram um estudo no qual avaliavam o sucesso do tratamento ortodôntico em 250 pacientes com má oclusão de Classe II divisão I entre 11 e 14 anos ao início do tratamento. Concluíram que havia uma associação entre a severidade inicial da má oclusão e a quantidade de duração do tratamento ortodôntico, o que reproduz a maior dificuldade do tratamento em relação à severidade inicial da má oclusão. 
Em 2002, WHEELER et. al. ${ }^{300}$ realizaram um trabalho no qual era avaliada a efetividade do tratamento precoce da Classe II com os aparelhos de tração extrabucal e o bionator. Os autores relacionaram o sucesso da correção da má oclusão com as características oclusais dos pacientes ao início do tratamento ortodôntico, principalmente a severidade da relação molar, gênero, raça e cooperação do paciente como fatores determinantes para o sucesso do tratamento ortodôntico.

Em 2003, CASSINELLI et al ${ }^{61}$ realizaram um estudo no qual avaliaram 10 ortodontistas quanto a relação entre severidade inicial da má oclusão e dificuldade no tratamento ortodôntico. Os ortodontistas deveriam escolher dentre os 100 últimos casos tratados, 10 que foram os mais difíceis de obtenção de sucesso e 10 em que o sucesso do tratamento foi facilmente obtido. Os casos foram avaliados pelo índice PAR e constatou-se que quanto maior era a severidade do caso no início do tratamento, mais difícil era a sua correção.

$\mathrm{KING}^{165}$ et al, em 2003, comparam os resultados dentoalveolares do tratamento em 1 ou 2 fases. Afirmam que a severidade da relação molar pode ser um fator mais confiável para predizer a efetividade do tratamento ortodôntico do que os valores encontrados no índice PAR.

FOGLE et al $^{102}$ em 2004, concluíram em seu trabalho que a terapia ortodôntica convencional obtém sucesso na correção da má oclusão de Classe II Divisão 1 para pacientes em crescimento. Salientaram que quanto maior a severidade inicial da má oclusão, tanto dentária quanto esquelética, maiores são as modificações induzidas pelo tratamento. 


\section{6 ÍNDICES DE AVALIAÇÃO OCLUSAL}

Os índices de classificação das más oclusões, de natureza quantitativa, foram propostos a partir da necessidade evidente quando da implementação do Programa de Reabilitação Dentária do Estado de Nova lorque, em 1945. Questões como elegibilidade e critérios de qualificação estavam entre os primeiros problemas enfrentados.

Segundo TANG; WEI ${ }^{271}$, os primeiros métodos para medir as más oclusões eram qualitativos, dentre os quais encontram-se: o método de $\mathrm{ANGLE}^{9}$, STALLARD $^{263}$, MCCALL $^{187}$, SCLARE ${ }^{252}$, FISK ${ }^{101}$, BJÖRK; KREBS; SOLOW ${ }^{41}$, PROFFIT; ACKERMAN ${ }^{219}$, e WHO/FDI ${ }^{204}$. Os índices criados para avaliarem a severidade das más oclusões, isto é, quantitativamente as más oclusões, foram inicialmente desenvolvidos entre 1950 e $1960^{85,289}$.

Atualmente, vários índices oclusais, utilizados para mensurar as más oclusões têm sido descritos na literatura norte-americana e alguns deles são aplicados para determinar o acesso à assistência pública na área ortodôntica, visto que neste país, e em vários países da Europa, uma significativa parcela dos tratamentos ortodônticos realizados está vinculada aos serviços de saúde pública. Além disso, mais recentemente estes índices estão sendo utilizados em pesquisas $^{255}$. Sendo assim, a aplicabilidade destes índices tem se tornado cada vez mais ampla. Segundo SHAW; RICHMOND; O'BRIEN ${ }^{255}$, os índices oclusais, de uma maneira geral, podem ajudar: (1) na distribuição mais coerente dos recursos destinados ao atendimento público, (2) na verificação e padronização dos tratamentos ortodônticos, (3) na melhor identificação das más oclusões que 
necessitam tratamento e (4) no consentimento por escrito do paciente nos casos em que a relação custo/benefício é desfavorável.

Em geral, os índices são criados com propósitos específicos como a avaliação de resultado, complexidade, necessidade do tratamento ou da severidade $^{140}$ das más oclusões. A utilização de um índice para um propósito diferente daquele inicialmente definido requer um estudo de validação do índice para esta nova finalidade.

O índice de prioridade de tratamento (IPT), elaborado por GRAINGER ${ }^{121}$, em 1967, teve como precursor o índice ESM (Estimativa da Severidade da Má oclusão) desenvolvido pelo mesmo autor no Burlington Orthodontic Research Centre. O propósito inicial para o desenvolvimento do IPT foi determinar se o tratamento ortodôntico reduzia a severidade da má oclusão abaixo do nível de significância utilizado na saúde pública. Portanto, este índice foi elaborado no intuito de avaliar o grau de melhora decorrente do tratamento ortodôntico.

HERMANSON; GREWE ${ }^{138}$, em 1970, testaram a precisão e as influências desfavoráveis de cinco índices de má oclusão, incluindo o IPT. Seus resultados mostraram que apenas o OI e o IPT não demonstraram significância e variabilidade entre diferentes examinadores, estando em nível de 1\%, sendo os índices mais precisos dentre os demais.

Em 1971, POPOVICH; THOMPSON ${ }^{216}$ consideraram a dificuldade em quantificar a severidade da má oclusão devido a sua subjetividade. Neste sentido, testaram o IPT como um instrumento que mostrasse a confiança ao ortodontista ou que pudesse ser utilizado em avaliações epidemiológicas da má oclusão. Para isto foram medidos mil quatrocentos e vinte pares de modelos, os mesmos da amostra do Centro de Pesquisa Ortodôntica de Burlington, jovens nas idades de 3, 6, 9, 12, 
14 e 16 anos. Os escores do IPT foram obtidos. Os modelos foram também avaliados por um ortodontista e seus escores subjetivos foram comparados com o do IPT. Concluíram que, para avaliação epidemiológica da má oclusão, o IPT teve mérito como índice para as idades de 3 a 16 anos, sendo que a importância de cada uma das sete síndromes permaneceu constante nesta extensão de idade. A porcentagem de prevalência da má oclusão foi mais consistente com o IPT do que a estimativa subjetiva do ortodontista, encontrando a maior diferença entre o IPT e os escores subjetivos pelo alto peso dado pelo ortodontista aos dentes girados ou deslocados. Também classificaram o IPT segundo as amplitudes de 0-2.5, 2.5-4.5 e maior que 4.5 como sendo os melhores limites para baixa, média e alta prioridade, respectivamente.

SUMMERS $^{269}$, em 1971, apresenta um índice para medir a oclusão epidemiologicamente, baseado na Estimativa da Severidade da Má Oclusão e no Índice e Prioridade de tratamento. Lembra que segundo a Organização Mundial da Saúde o índice oclusal deve ser reproduzível, medir exclusivamente o que se pretende e considerar o desenvolvimento normal da oclusão, no qual os fatores etiológicos atuam causando problemas esqueletéticos, dentários e/ou neuromusculares. $\mathrm{O}$ método consiste em avaliar nove características: idade dentária, relação molar, sobressaliência horizontal, sobremordida, mordida cruzada posterior, mordida aberta posterior, deslocamento dentário, relação de linhas médias e incisivos superiores permanentes perdidos. Foi encontrada uma alta correlação clínica para o novo índice e a característica de ser também reproduzível.

O Índice de Prioridade de Tratamento (IPT) foi utilizado por LEWIS et al. ${ }^{175}$, em 1982, para determinar a confiança e valor dos julgamentos clínicos da má oclusão. Para isso, utilizaram cinqüenta pares de modelos em que os examinadores 
avaliaram inicialmente seis dimensões: necessidade de tratamento, grau de má oclusão, potencial para perda tecidual, efeito negativo na estabilidade oclusal, efeito negativo no aspecto dentofacial e efeito negativo na função mastigatória. Após seis semanas os mesmos examinadores utilizaram o IPT para obter os escores dos mesmos modelos. Novamente os modelos foram avaliados três semanas mais tarde com relação à necessidade de tratamento e grau da má oclusão. O resultado confirmou a confiança nas avaliações clínicas, com uma forte correlação do IPT com a necessidade de tratamento, grau de má oclusão e atrativo dentofacial, sendo este último o de maior valor pela presença de sobressaliência horizontal e deslocamentos dentários óbvios.

Mais recentemente GHAFARI; LOCKE; BENTLEY ${ }^{110}$, ressaltaram que o IPT é um excelente indicador da presença de má oclusão. Desde então, o índice IPT tem sido utilizado por outros autores, seja como um eficiente indicador da presença e severidade da má oclusão, seja como um confiável instrumento de avaliação da eficácia do tratamento ortodôntico ${ }^{110,149,150}$.

Estudando a aplicação do IPT na dentadura mista TURNER ${ }^{280}$ observou que um dos fatores responsáveis pela menor validade do IPT neste estágio de desenvolvimento da oclusão era o grau de sobremordida. De fato, observando a tabela 3 da medida de sobremordida, utilizada por GRAINGER ${ }^{121}$ na elaboração do índice IPT pode-se confirmar que o grau de sobremordida varia com a idade e para o índice manter o seu grau de validade constante ele teria que ajustar os seus valores referenciais de acordo com a idade da amostra estudada.

De acordo com SHAW et al. ${ }^{256}$, um índice oclusal deve deter alguns requisitos importantes tais como fácil aplicação, boa reprodutibilidade, sensibilidade às mudanças oclusais para melhor ou pior, mínimo grau de subjetividade para 
aplicação, confiabilidade e validade para o fim a que se propõe. Estes requisitos, segundo RICHMOND et al. ${ }^{232}$ são preenchidos pelo índice PAR, criado em 1987 com o intuito de fornecer um único valor para todas as anomalias oclusais que podem ser encontradas em uma mesma má oclusão. Este índice, elaborado por um grupo de dez ortodontistas britânicos, foi julgado válido e confiável para avaliar os resultados oclusais do tratamento ortodôntico por um grupo de 74 examinadores, compostos por 48 especialistas em ortodontia e 26 clínicos gerais. Os autores concluíram que o índice PAR oferece uniformidade e padronização em avaliar os resultados do tratamento ortodôntico. Os resultados do tratamento são estimados a partir da diferença calculada entre os valores dos índices obtidos nas fases pré e pós-tratamento, sendo que o valor numérico desta diferença é inversamente proporcional ao grau de melhora obtido com o tratamento ortodôntico ${ }^{232}$.

Posteriormente à sua elaboração e publicação, o índice PAR foi reavaliado por um grupo de onze ortodontistas Norte-Americanos quanto à sua eficácia em retratar o grau de severidade das más oclusões e o nível de complexidade do tratamento. A eficácia do índice foi considerada melhor quando novos pesos foram computados a cada um dos componentes do índice. Mediante estas modificações os autores puderam, então, concluir que o índice PAR constituiu um eficiente método de investigação da eficácia do tratamento ortodôntico a partir da avaliação das mudanças oclusais ${ }^{79}$. Certamente, a maior repercussão desta nova distribuição dos pesos foi a eliminação do apinhamento ântero-inferior como variável que contribui para a predição da severidade da má oclusão. A explicação para esta questão foi a facilidade em alinhar os dentes após a realização de extrações. Contudo, deve-se considerar que a necessidade de extrações já é um premonitório da severidade da má oclusão ${ }^{142,279}$, sem contar que em alguns casos a complexidade do tratamento 
aumenta mediante a realização de extrações, como, por exemplo, no tratamento da má oclusão de Classe II com indicação de extrações inferiores ${ }^{150}$.

Considerando que o propósito de avaliação realizada pelo índice IPT é mais condizente com as características do estudo empreendido e que ele apresentou as menores limitações operacionais, este índice foi aplicado aos modelos de estudo da amostra selecionada neste trabalho. 

Proposição 



\section{PROPOSIÇÃo}

Esse estudo tem como objetivo:

1. Comparar, por meio do Índice de Prioridade de Tratamento (IPT) a proporção de sucesso do tratamento sem extração da má oclusão de Classe II de acordo com a severidade inicial representada por pacientes com $1 \frac{1}{2}$ Classe II e com Classe II completa bilateral.

Com a finalidade de fornecer resultados mais completos em relação ao sucesso do tratamento ortodôntico sem extração de acordo com o grau de severidade inicial da má oclusão, adicionalmente realizou-se:

2. A comparação do tempo de tratamento e;

3. A comparação do índice de eficiência de tratamento entre os grupos. 



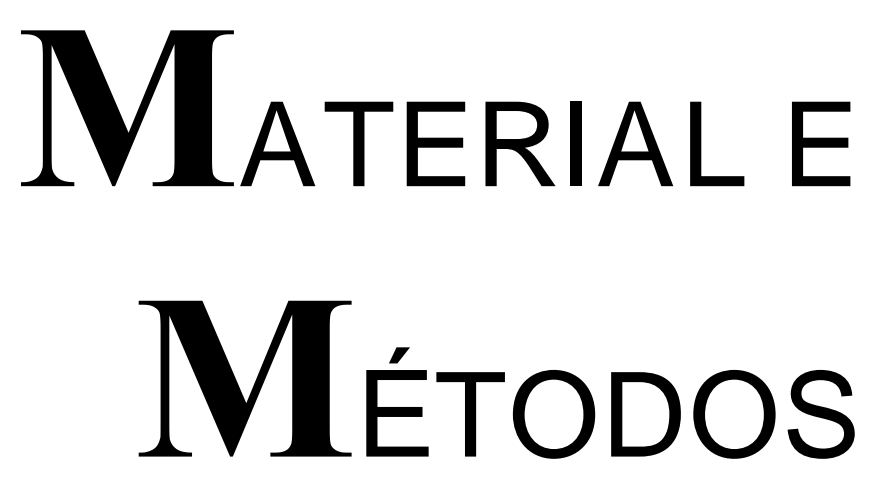





\section{MATERIAL E MÉTODOS}

\subsection{MATERIAL}

Foi selecionado dentre os 4.000 pacientes tratados nos cursos de PósGraduação Latu Sensu e Stricto Sensu da Disciplina de Ortodontia da Faculdade de Odontologia de Bauru - USP o número máximo de pacientes tratados e que obedecem aos critérios de seleção descritos abaixo para constituírem a amostra deste trabalho.

Estes pacientes deveriam apresentar necessariamente os seguintes requisitos:

1. Más oclusões de Classe II de duas diferentes severidades, $1 / 2$ Classe II ou Classe II completa ao início do tratamento ortodôntico;

2. As más oclusões deveriam apresentar, necessariamente, a mesma severidade bilateralmente;

3. Os casos deveriam ter sido tratados com a mecanoterapia fixa e não poderia haver extrações em seu plano de tratamento inicial;

4. Presença de todos os dentes permanentes ao final do tratamento, excetuando-se terceiros molares;

5. Ausência de dentes supranumerários, impactados, agenesias e anomalias quanto ao tamanho e/ou forma dos dentes;

6. Documentação ortodôntica completa ao início e final de tratamento assim como os modelos de gesso em boas condições; 
Todos os pacientes que preencheram esses critérios foram selecionados para comporem a amostra. A amostra foi dividida em dois grupos experimentais mediante a severidade da má oclusão:

Grupo 1: pacientes com má oclusão de 1/2 Classe II;

Grupo 2: pacientes com má oclusão de Classe II completa;

O Grupo 1 foi constituído de 144 pacientes que apresentavam, ao início do tratamento, má oclusão de 1/2 Classe II, com idade inicial média de 12,27 anos (idade mínima de 8,58 e máxima de 16,66). Destes:

- 78 pacientes eram do gênero feminino enquanto os outros 66 pacientes pertenciam ao gênero masculino;

- 84 pacientes apresentavam-se na fase de dentadura permanente e 60 na fase de dentadura mista, e;

- 121 pacientes com má oclusão de Classe II divisão 1, enquanto 23 com Classe II divisão 2; 

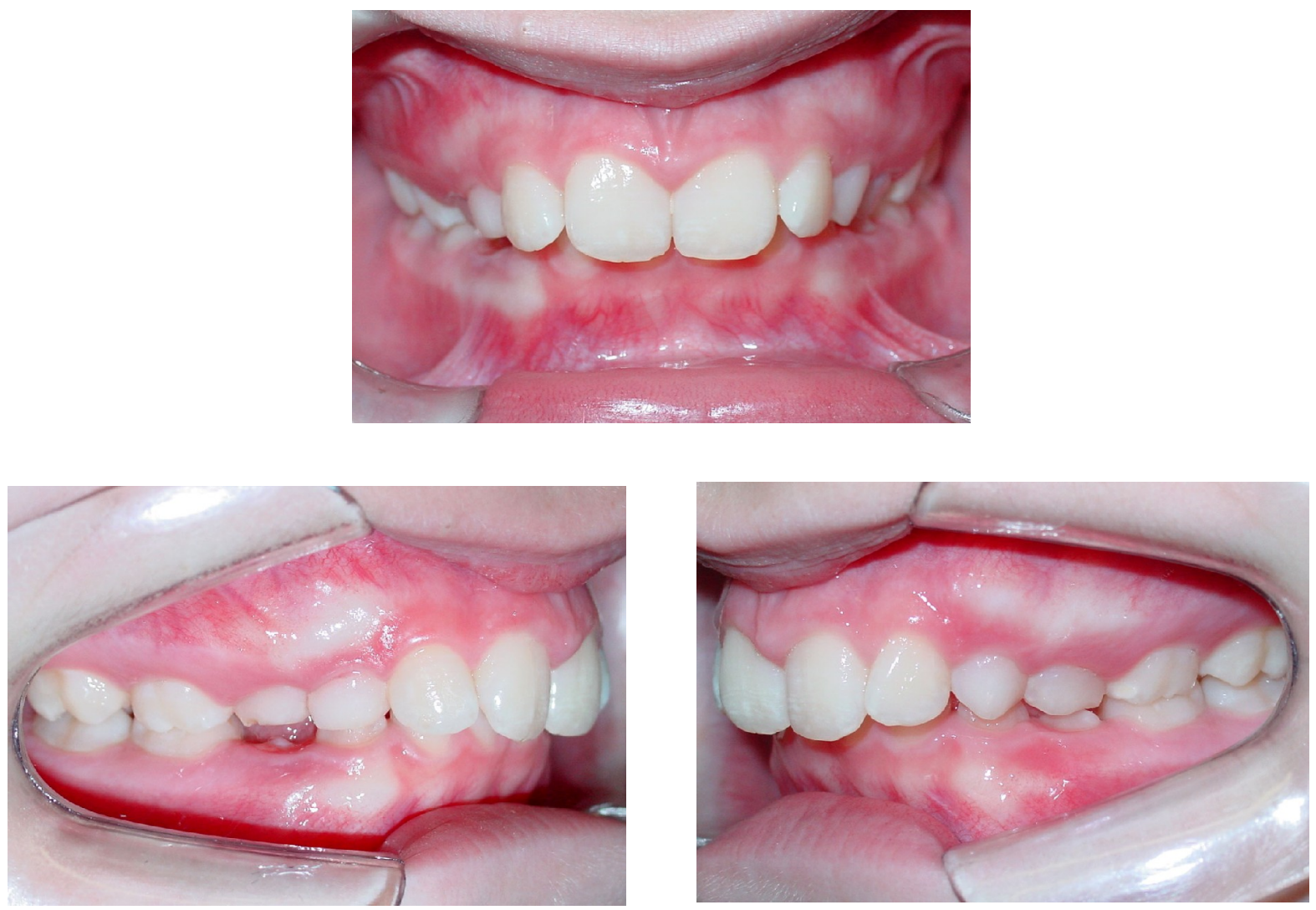

Figura 1 - Má oclusão de 1⁄2 Classe II

O Grupo 2 foi composto por 133 pacientes e subdividido em dois grupos: 2A e 2B. O Grupo 2A foi constituído por 107 pacientes que apresentavam, no início do tratamento, má oclusão de Classe II completa com idade inicial média de 12,24 anos (idade mínima de 7,91 e máxima de 16,33). Destes pacientes:

- 58 eram do gênero feminino e 49 do masculino;

- 51 apresentavam-se na fase de dentadura permanente e 56 na dentadura mista, e;

- 92 com má oclusão de Classe II divisão 1, enquanto 15 com Classe II divisão 2. 
O Grupo 2B foi constituído por 26 pacientes com idade inicial média de 12,99 anos(idade mínima de 9,42 e máxima de 21,50) que apresentavam, ao início do tratamento, má oclusão de Classe II completa e foram submetidos ao replanejamento, no decorrer do tratamento, devido à tentativa mal sucedida de se corrigir a Classe II sem extrações dentárias. O grupo 2B apenas foi utilizado neste estudo, somado ao Grupo 2A, para expressar a real quantidade de pacientes com Classe II completa que ao início do tratamento ortodôntico foram planejados sem extração. Com isso conseguiu-se definir exatamente a porcentagem de pacientes desse grupo que alcançaram o sucesso do tratamento, como descrito detalhadamente na discussão deste trabalho.
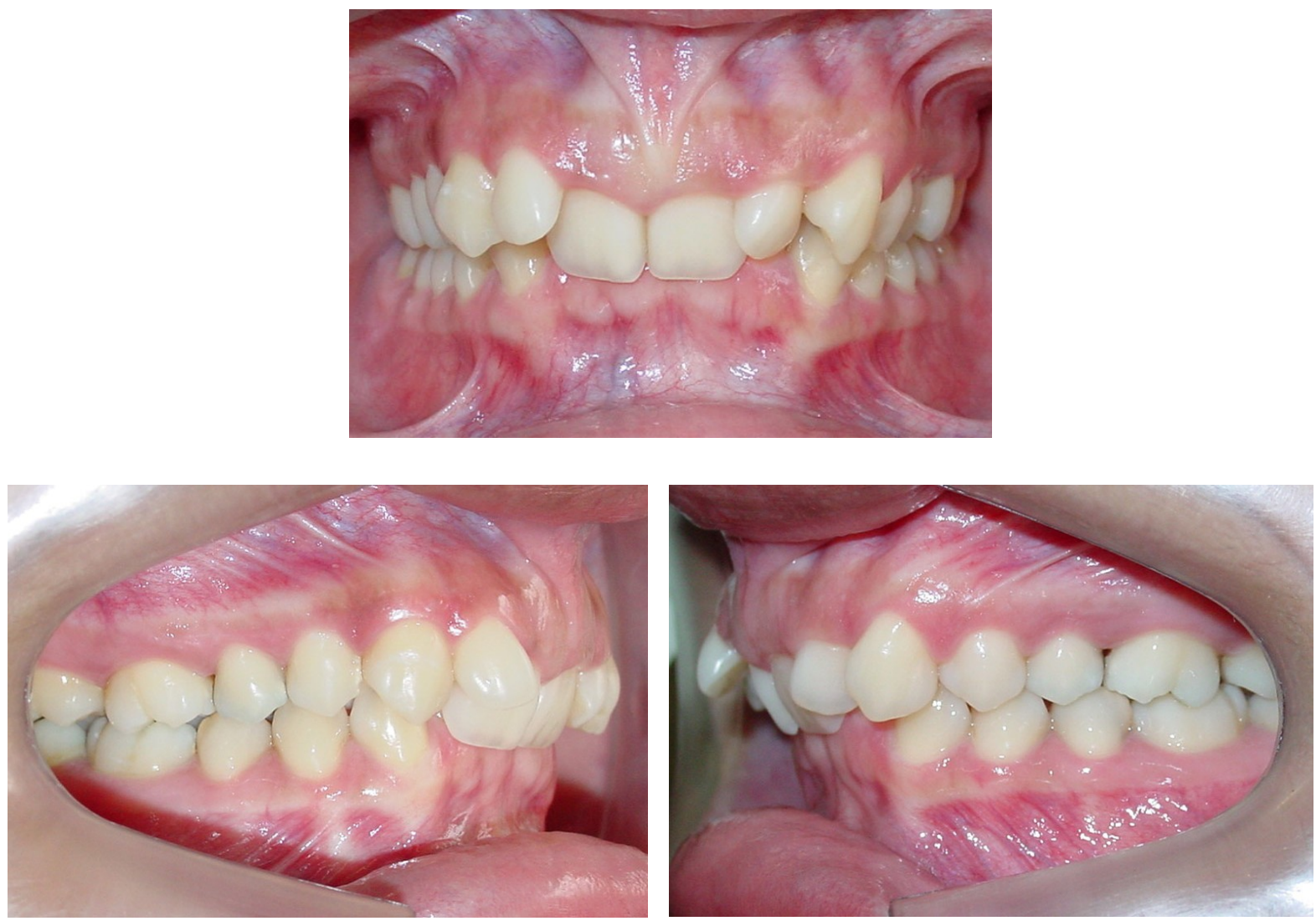

Figura 2 - Má oclusão de Classe II completa 
Tabela 1 - Médias, desvios-padrão, mínimo e máximo das idades dos grupos experimentais no início do tratamento ortodôntico.

\begin{tabular}{c|c|c|c|c|c}
\hline \multirow{2}{*}{ Pacientes } & \multicolumn{4}{c}{ Idade } \\
\cline { 3 - 6 } \multicolumn{2}{c|}{} & Média & Desvio Padrão & Mínimo & Máximo \\
\hline \multicolumn{2}{c|}{ Grupo 1 } & 12,27 & 1,49 & 8,58 & 16,66 \\
\hline Grupo & 2A & 12,24 & 1,45 & 7,91 & 16,33 \\
\cline { 2 - 6 } & 2B & 12,99 & 2,37 & 9,42 & 21,50 \\
\hline
\end{tabular}

Tabela 2 - Gênero, tipo de má oclusão, dentadura e total de pacientes dos grupos experimentais no início do tratamento ortodôntico.

\begin{tabular}{c|c|c|c|c|c|c|c|c|c}
\hline \multirow{2}{*}{ Pacientes } & \multicolumn{2}{|c|}{ Gênero } & \multicolumn{2}{c|}{ Tipo de Classe II } & \multicolumn{2}{c|}{ Dentadura } & \multicolumn{2}{c}{ Total } \\
\cline { 2 - 9 } \multicolumn{2}{c|}{} & Masc. & Fem. & Div. 1 & Div. 2 & Permanente & Mista & \multicolumn{2}{c}{} \\
\hline \multicolumn{2}{c|}{ Grupo 1 } & 66 & 78 & 121 & 23 & 84 & 60 & \multicolumn{2}{|c}{144} \\
\hline \multirow{2}{*}{ Grupo 2 } & 2A & 49 & 58 & 92 & 15 & 51 & 56 & 107 & \multirow{2}{*}{133} \\
\cline { 2 - 10 } & 2B & 13 & 13 & 19 & 7 & 20 & 6 & 26 & \\
\hline
\end{tabular}

\subsection{MÉTODOS}

\subsubsection{Documentação Ortodôntica}

As pastas ortodônticas relativas à amostra selecionada no arquivo da Disciplina de Ortodontia da Faculdade de Odontologia de Bauru, Universidade de São Paulo, foram utilizadas para a obtenção de alguns dados relevantes à realização deste trabalho.

- Utilizou-se a ficha de dados cadastrais para o registro do nome completo dos pacientes, gênero e data de nascimento, possibilitando a determinação exata da idade cronológica do paciente no início do tratamento; 
- A ficha do planejamento terapêutico inicial de cada paciente foi consultada quanto ao protocolo de tratamento proposto, sobretudo com referência à decisão pelo tratamento sem extração para a correção da má oclusão de Classe II.

- As fichas de procedimentos terapêuticos foram examinadas quanto às datas de início e término do tratamento. Estes dados permitiram a determinação exata do tempo total de tratamento;

- O relatório final do tratamento foi avaliado, principalmente, quanto ao cumprimento do planejamento inicial, identificando os casos em que as dificuldades encontradas durante o tratamento levaram ao replanejamento por extrações dentárias.

\subsubsection{Análise dos modelos}

Os modelos de gesso pré e pós-tratamento de cada paciente foram utilizados. Nos modelos iniciais avaliou-se a severidade da má oclusão inicial de acordo com o $\mathrm{IPT}^{121}$ (índice de prioridade de tratamento). O objetivo foi quantificar e avaliar por meio de escores, a relação molar, a sobressaliência, a sobremordida, o apinhamento, a rotação dentária e a mordida cruzada. Os modelos pós-tratamento foram utilizados para definir o sucesso do tratamento ortodôntico. Somente foi considerado sucesso do tratamento ortodôntico os casos concluídos com índices satisfatórios para final de tratamento. Estabeleceu-se como norma para o sucesso do tratamento, no máximo, 2 pontos para o IPT (Índice de Prioridade de Tratamento). 


\subsubsection{O Índice de Prioridade de Tratamento (IPT)}

O índice oclusal IPT foi utilizado para avaliar quantitativamente as relações oclusais intra e interarcos, observadas nos modelos de gesso pré e pós-tratamento dos 144 pacientes do Grupo 1 e dos 107 pacientes do Grupo 2A. Esse índice foi elaborado em 1967 por GRAINGER ${ }^{121}$. O IPT foi calculado por meio dos modelos de gesso, nas fases pré e pós-tratamento de cada paciente, a partir de uma tabela (Tabela 3) onde estão sintetizadas a principais características da oclusão a serem avaliadas, bem como os parâmetros necessários a esta avaliação.

\section{Relação Molar}

O primeiro passo para a obtenção deste índice é a classificação da relação molar que definirá tanto a coluna da tabela a ser utilizada, quanto a constante numérica a ser acrescentada ao valor final do índice. Uma vez que os critérios de seleção aplicados neste estudo requeriam a presença da má oclusão de 1/2 Classe II ou de Classe II completa, bilateral, ao início do tratamento, todos os pacientes do Grupo 1 foram inicialmente incluídos na terceira coluna da Tabela 3, com um valor constante a ser somado ao resultado final do índice de 2,72 pontos. Já os pacientes do Grupo 2A foram inicialmente incluídos na primeira coluna da Tabela 3, a qual apresenta um valor constante a ser somado no resultado final do índice de 5,17 pontos.

\section{Sobressaliência}

Uma vez definida a coluna apropriada ao tipo de má oclusão, o próximo passo constitui na mensuração em milímetros da quantidade de sobressaliência, tomando- 
se como referência a inicisal dos incisivos superiores em relação à face vestibular dos incisivos inferiores. A partir do valor desta medida pode-se estimar na Tabela 3 o escore correspondente.

\section{Sobremordida}

A quantificação da sobremordida foi realizada tomando como referência a quantidade de terços da coroa dos incisivos inferiores que se encontravam encobertos pelos incisivos superiores, obtendo-se na Tabela 3 o valor do escore correspondente.

\section{Apinhamento}

O apinhamento total foi avaliado a partir da contagem do número de dentes que se encontravam deslocados no mínimo $2 \mathrm{~mm}$ ou girados no mínimo 45em relação às suas posições ideais (apinhamento e/ou rotação). O somatório final obtido desta contagem foi utilizado para determinar na Tabela 3 o escore aplicado ao apinhamento.

\section{Mordida Cruzada}

A contagem total do número de dentes posteriores cruzados por lingual ou vestibular foi o critério utilizado para determinar, na Tabela 3, o escore referente a este item.

Uma vez obtidos os escores para todos os itens que compõem o índice, procedeu-se à soma total dos escores que foi ainda acrescida por uma constante de valor condizente como a relação molar inicialmente avaliada. Baseando-se nos 
critérios descritos no texto e utilizando os valores de escores especificados na Tabela 3, calculou-se o índice IPT a partir do somatório total dos resultados parciais de seus componentes para cada um dos 502 pares de modelos (288 pares de modelos do grupo 1 e 214 pares de modelos do grupo 2A). Sendo que o índice IPT foi denominado IPT inicial (IPTI) quando obtido a partir dos modelos pré-tratamento e, IPT final (IPTF) quando calculado nos modelos pós-tratamento. 
Tabela 3 - Apresentação dos pesos que compõem o Índice de Prioridade de Tratamento (IPT) proposto por GRAINGER ${ }^{121}$.

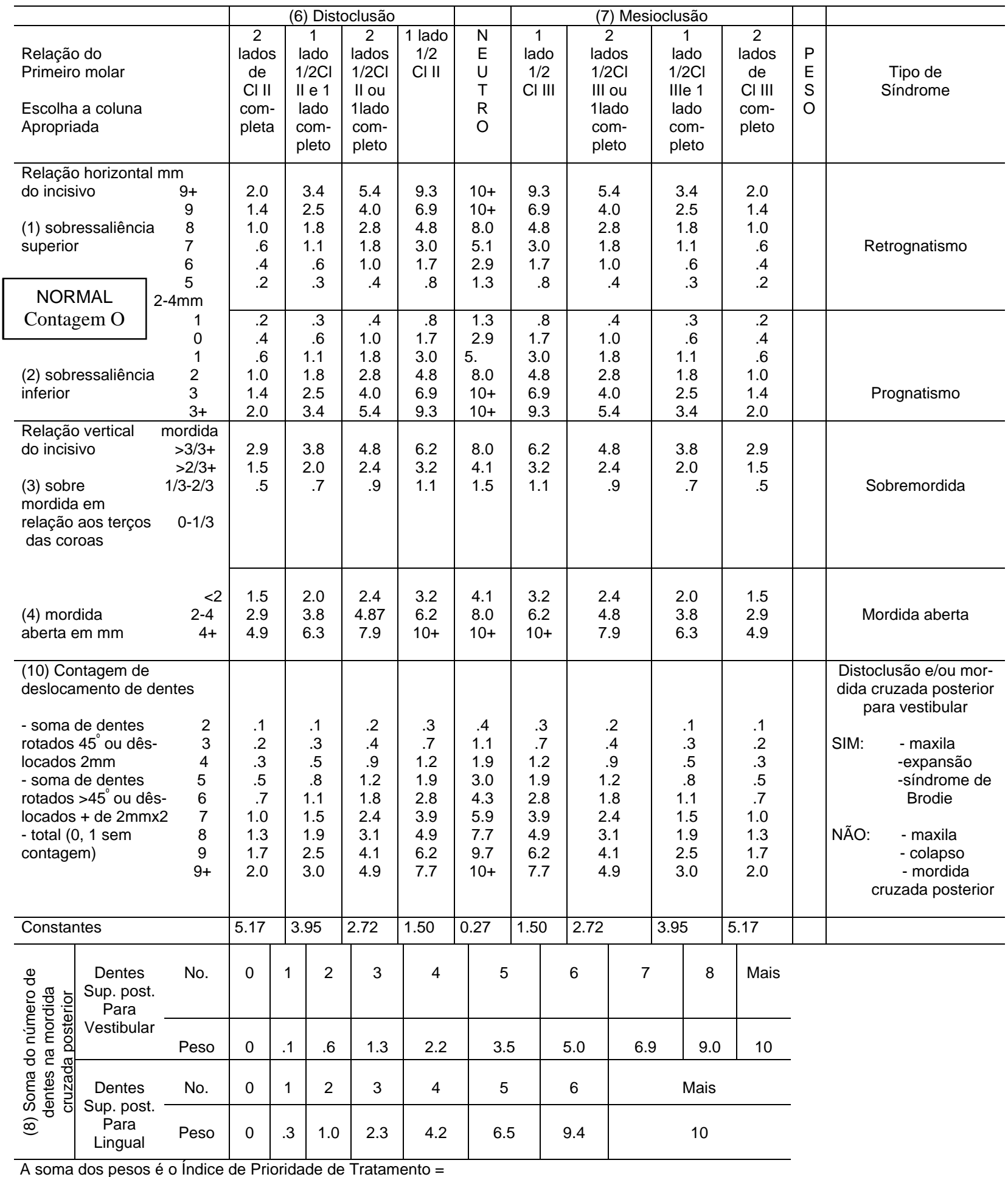


Uma vez que o índice IPT foi obtido por meio da aplicação de escores que classificam numa escala ordinal a mensuração das relações dentárias intra (apinhamento) e interarcos (sobremordida, sobressaliência, mordida cruzada), a partir de um valor 0 de normalidade, quanto maior o valor numérico deste índice, maior será o desvio da oclusão analisada em relação à normalidade.

A diferença entre os valores inicial e final do índice IPT (DIFIPT) foi calculada para expressar a quantidade de melhora decorrente do tratamento. A partir desta medida obteve-se, também, o percentual de melhora (PCIPT) descrito pela equação abaixo $^{21,150}$ análogo a diversos estudos ${ }^{17,32,232,233}$.

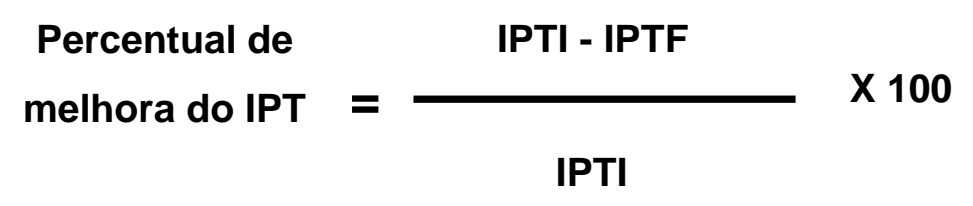

Todas as medidas iniciais e finais referentes à quantidade de trespasse horizontal, vertical e apinhamento, foram obtidas nos modelos pré e pós-tratamento utilizando-se um paquímetro da marca $M A U B^{1}$ capaz de imprimir às medidas realizadas uma precisão de até $0,1 \mathrm{~mm}$.

\subsubsection{O índice de eficiência do tratamento (IET)}

Como descrito por BARROS ${ }^{21}$, em 2004, e considerando que a eficiência representa a obtenção dos melhores rendimentos com um mínimo dispêndio de tempo, o grau de eficiência do tratamento foi avaliado a partir de um índice definido

${ }^{1}$ FWP, Maub, Polland 
pela razão entre o percentual de melhora (PCIPT) e o tempo de tratamento em meses, sendo expresso pela seguinte igualdade:

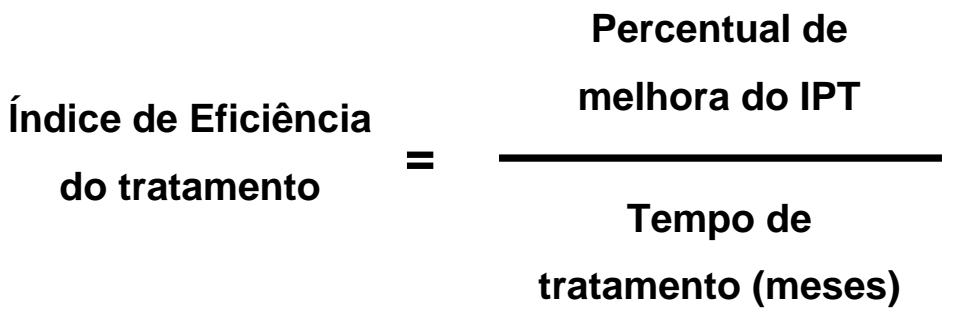

A partir desta relação matemática pode-se dizer que o percentual de melhora guarda uma relação direta com o índice de eficiência, enquanto o tempo de tratamento mantém uma relação inversa com este índice. Sendo assim, o valor do índice de eficiência aumenta na medida em que percentuais de melhora maiores associam-se a tempos de tratamento menores.

\subsubsection{Abreviaturas utilizadas para representar as variáveis estudadas}

Com o intuito de simplificar a manipulação e tabulação dos dados, as diversas variáveis consideradas neste estudo receberam abreviaturas descritas da seguinte forma: 
Tabela 4 - abreviaturas utilizadas no trabalho.

\begin{tabular}{c|c|l}
\hline \multicolumn{2}{l}{ ABREVIATURAS } & \multicolumn{1}{|c}{ DESCRIÇÃO } \\
\hline $\mathbf{1}$ & IDADEI & Idade inicial \\
\hline $\mathbf{2}$ & IPTI & Índice de prioridade de tratamento inicial \\
\hline $\mathbf{3}$ & IPTF & Índice de prioridade de tratamento final \\
\hline $\mathbf{4}$ & DIFIPT & Quantidade de redução do índice de prioridade de tratamento \\
\hline $\mathbf{5}$ & PCIPT & Percentual de redução do índice de prioridade de tratamento \\
\hline $\mathbf{6}$ & TTRAT & Tempo de tratamento total \\
\hline $\mathbf{7}$ & IETIPT & Índice de eficiência do tratamento - IPT \\
\hline
\end{tabular}

Uma vez obtidos os valores iniciais e finais, a quantidade de melhora, o percentual de melhora e o grau de eficiência referente ao índice IPT para cada um dos 144 pacientes do Grupo 1 e para os 107 pacientes do Grupo 2A, passou-se à análise estatística dos resultados.

\subsubsection{Análise Estatística}

\subsubsection{Erro do método}

O erro intra-examinador foi avaliado tomando-se novas medidas e calculandose um novo índice para os modelos iniciais e finais de 30 pacientes de ambos os grupos, selecionados aleatoriamente, totalizando 60 pares de modelos. $O$ tempo entre as medições foi de 30 dias (Tabela 5). A fórmula proposta por DAHLBERG ${ }^{73}$ $\left(\mathrm{Se}^{2}=\mathrm{S} \mathrm{d}^{2} / 2 \mathrm{n}\right)$ foi aplicada para estimar a ordem de grandeza dos erros casuais, 
enquanto os erros sistemáticos foram analisados pela aplicação do teste $t$ pareado, de acordo com HOUSTON ${ }^{143}$.

\subsubsection{Análise estatística entre grupos e variáveis}

A compatibilidade dos Grupos 1(1/2 Classe II) e 2A(Classe II completa) em relação a proporção entre os gêneros, dentadura e tipo de Classe II foi avaliada pelo teste Qui-Quadrado.

A compatibilidade dos grupos em relação à idade inicial (IDADEI) foi avaliada pelo teste $t$ não pareado. Esse mesmo teste também foi utilizado para avaliar a severidade inicial da má oclusão entre os grupos (IPTI).

Considerando-se a norma instituída para o sucesso do tratamento ortodôntico, descrita no início desse capítulo (no máximo, 2 pontos para o IPT), realizou-se o teste Qui-Quadrado entre as porcentagens dos pacientes que obtiveram o sucesso do tratamento ortodôntico em relação ao total de pacientes. Para se fazer essa comparação entre as porcentagens dos grupos 1 e 2 foram utilizados os pacientes do Grupo 2B que somados aos pacientes do Grupo 2A compunham o total de pacientes que ao início do tratamento apresentavam má oclusão de Classe II completa. Isso se deveu ao fato dos pacientes do Grupo 2B terem sido replanejados com realizações de extrações ao longo do tratamento ortodôntico devido à tentativa mal sucedida de se corrigir a Classe II sem extrações. Quando do replanejamento por extrações, esses pacientes automaticamente foram excluídos dos cálculos para comparação dos pacientes 1/2 Classe II e Classe II completa tratados sem extração, mas fazem parte do trabalho, pois devem ser inseridos para o cálculo da porcentagem exata de pacientes que obtiveram sucesso 
do tratamento ortodôntico desde o início de seu planejamento. O cálculo da proporção de sucesso entre os grupos 1 e 2A também foi realizada pelo teste QuiQuadrado, ou seja, foi realizado também o teste para verificar a proporção de sucesso excluindo-se os pacientes replanejados.

A seguir, o teste $t$ não pareado foi aplicado a variável IPTF para comparação das características oclusais presentes ao final do tratamento entre os grupos 1 e $2 \mathrm{~A}$. Comparação semelhante foi também realizada para as variáveis que expressavam a quantidade de melhora (DIFIPT), o percentual de melhora (PCIPT), e o tempo de tratamento (TTRAT). Além disso, o teste $t$ não pareado foi também utilizado para comparar o grau de eficiência do tratamento (IETIPT) entre os grupos.

Todos os testes foram realizados com o programa STATISTICA ${ }^{2}$, adotando-se um nível de significância de 5\%.

\footnotetext{
${ }^{2}$ Statistica for Windows - Release 5.0 - Copyright StatSoft, Inc. 1995.
} 

Resultados 



\section{RESULTADOS}

Os resultados estão apresentados sob a forma de tabelas. A tabela 5 apresenta os resultados da avaliação dos erros sistemáticos ${ }^{143}$ e casuais ${ }^{73}$, por meio da aplicação do teste $t$ pareado e da fórmula de Dahlberg ${ }^{73}$ respectivamente, aplicados às variáveis IPTI, IPTF.

A tabela 6 representa os resultados do teste Qui-Quadrado para avaliar a compatibilidade dos grupos 1 ( $1 \frac{2}{2} \mathrm{CI}$ II) e 2A (Cl II completa) em relação ao gênero, tipo de Classe II e fase da dentadura.

A compatibilidade dos grupos em relação à idade inicial também foi realizada e está representada na tabela 7 . Nesta mesma tabela encontra-se o resultado da comparação da severidade inicial da má oclusão entre os grupos 1 (1/2 Cl II) e $2 \mathrm{~A}(\mathrm{Cl}$ II completa).

A tabela 8 apresenta o resultado do teste Qui-Quadrado entre as porcentagens de sucesso do tratamento ortodôntico entre os grupos 1 e 2 , sendo que o grupo 2 inclui todos os casos de Classe II completa inicialmente planejados sem extração, tenha sido o caso replanejado ou não após o início do tratamento. A tabela 9 mostra o resultado do teste Qui-Quadrado entre as porcentagens do tratamento ortodôntico entre os grupos 1 e 2A, ou seja, para ser constituído o grupo 2A foram excluídos os pacientes replanejados com extrações do grupo 2 .

A tabela 10 apresenta os resultados do teste $t$ não pareado aplicado às variáveis IPTF, DIFIPT, PCIPT, TTRAT, IETIPT para comparação destas entre os grupos $1(1 / 2 \mathrm{Cl}$ II) e $2 \mathrm{~A}$ (Cl II completa). 
Tabela 5 - Resultados do teste $t$ pareado e da fórmula de DAHLBERG ${ }^{73}$, aplicados às variáveis IPTI; IPTF; para estimar os erros sistemáticos e casuais, respectivamente.

\begin{tabular}{c|c|c|c|c|c|c}
\hline \multirow{2}{*}{ Variáveis } & \multicolumn{2}{|c|}{$\mathbf{1}^{\text {a }}$ medição $\mathbf{N}=\mathbf{3 0}$} & \multicolumn{2}{|c|}{$\mathbf{2}^{\text {a }}$ medição $\mathbf{N}=30$} & \multirow{2}{*}{$\mathbf{p}$} & \multirow{2}{*}{ Dahlberg } \\
\cline { 2 - 5 } & média & D.P. & média & D.P. & & \\
\hline IPTI & 8,12 & 1,64 & 8,22 & 1,41 & 0,62 & 0,85 \\
\hline IPTF & 1,87 & 1,70 & 1,69 & 1,58 & 0,11 & 0,43 \\
\hline
\end{tabular}

Tabela 6 - Resultados do teste Qui-Quadrado para avaliar a compatibilidade dos grupos 1 ( $1 / 2 \mathrm{Cl}$ II) e 2A (Cl II completa) em relação ao gênero, tipo de Classe II e a quantidade de pacientes na fase de dentadura mista e permanente.

\begin{tabular}{|c|c|c|c|c|c|c|}
\hline \multicolumn{2}{|c|}{ Amostra } & \multicolumn{2}{|c|}{$\begin{array}{l}\text { Grupo } 1 \\
(1 / 2 \mathrm{Cl} \text { II) }\end{array}$} & \multicolumn{2}{|c|}{$\begin{array}{c}\text { Grupo 2A } \\
\text { (Cl Il completa) }\end{array}$} & \multirow[t]{2}{*}{$\mathbf{p}$} \\
\hline & & pacientes & $\%$ & pacientes & $\%$ & \\
\hline \multirow{2}{*}{ Gênero } & masculino & 66 & 45,83 & 49 & 45,79 & \multirow{2}{*}{0,9950} \\
\hline & feminino & 78 & 54,17 & 58 & 54,21 & \\
\hline \multirow{2}{*}{$\begin{array}{c}\text { Tipo de Cl } \\
\text { II }\end{array}$} & Div. 1 & 121 & 84,03 & 92 & 85,99 & \multirow{2}{*}{0,6687} \\
\hline & Div. 2 & 23 & 15,97 & 15 & 14,01 & \\
\hline \multirow{2}{*}{ Dentadura } & Mista & 60 & 41,67 & 56 & 52,34 & \multirow{2}{*}{0,1174} \\
\hline & Permanente & 84 & 58,33 & 51 & 47,66 & \\
\hline \multicolumn{2}{|c|}{ total } & 144 & 100 & 107 & 100 & \\
\hline
\end{tabular}

Tabela 7 - Resultados do teste $t$ independente, aplicado às variáveis IDADEI (idade inicial) e IPTI (IPT inicial) para os grupos 1 ( $1 / 2 \mathrm{Cl} \mathrm{II}$ ) e $2 \mathbf{A}$ (Cl II completa).

\begin{tabular}{c|c|c|c|c|c}
\hline \multirow{2}{*}{ VARIÁVEIS } & \multicolumn{2}{|c|}{ GRUPO 1 $\mathbf{N}=1 \mathbf{1 4 4}$ CI II) } & \multicolumn{2}{c|}{$\begin{array}{c}\text { GRUPO 2A } \\
\text { (CI II completa) }\end{array}$} & P \\
\cline { 2 - 5 } & média & D.P. & média & D.P. & \\
\hline IDADEI & 12,27 & 1,49 & 12,24 & 1,45 & 0,9035 \\
\hline IPTI & 7,87 & 2,22 & 9,00 & 1,48 & 0,0000 \\
\hline
\end{tabular}


Tabela 8 - Resultados do teste Qui-Quadrado entre as porcentagens de sucesso do tratamento ortodôntico entre os grupos $1(1 / 2 \mathrm{Cl}$ II) e 2 (CI II completa conjuntamente aos pacientes replanejados).

\begin{tabular}{c|c|c|c|c|c}
\hline \multirow{2}{*}{ VARIÁVEIS } & \multicolumn{2}{|c|}{ PROPORÇÃO DE SUCESSO DO TRATAMENTO } & \multirow{2}{*}{ P } \\
\cline { 2 - 5 } & \multicolumn{2}{|c|}{$\begin{array}{c}\text { Grupo 1 (n=144) } \\
(1 / 2 \text { CI II) }\end{array}$} & \multicolumn{2}{c}{ (CI II completa) } & \\
\cline { 2 - 5 } & pacientes & $\%$ & pacientes & $\%$ & \\
\hline IPTF < 2 & 114 & 79,17 & 67 & 50,37 & 0,0000 \\
\hline
\end{tabular}

Tabela 9 - Resultados do teste Qui-Quadrado entre as porcentagens de sucesso do tratamento ortodôntico entre os grupos 1 ( $1 / 2 \mathrm{CI}$ II) e $\mathbf{2 A}$ (CI II completa).

\begin{tabular}{|c|c|c|c|c|c|}
\hline \multirow{3}{*}{ VARIÁVEIS } & \multicolumn{4}{|c|}{ SUCESSO DO TRATAMENTO } & \multirow{3}{*}{$\mathbf{P}$} \\
\hline & \multicolumn{2}{|c|}{$\begin{array}{c}\text { Grupo } 1(n=144) \\
(1 / 2 \text { CI II) }\end{array}$} & \multicolumn{2}{|c|}{$\begin{array}{l}\text { Grupo 2A ( } \mathrm{n=107)} \\
\text { (CI Il completa) }\end{array}$} & \\
\hline & pacientes & $\%$ & pacientes & $\%$ & \\
\hline IPTF $<2$ & 114 & 79,17 & 67 & 62,61 & 0,0042 \\
\hline
\end{tabular}

Tabela 10 - Resultados do teste $t$ independente aplicado às variáveis estudadas nos grupos $1(1 / 2 \mathrm{Cl}$ II) e $\mathbf{2 A}$ (CI II completa).

\begin{tabular}{|c|c|c|c|c|c|}
\hline \multirow[t]{2}{*}{ VARIÁVEIS } & \multicolumn{2}{|c|}{$\begin{array}{c}\text { GRUPO } 1 \quad N=144 \\
(1 / 2 \text { Cl II })\end{array}$} & \multicolumn{2}{|c|}{$\begin{array}{c}\text { GRUPO 2A } \quad \mathrm{N}=107 \\
\text { (CI II completa) }\end{array}$} & \multirow[t]{2}{*}{$\mathbf{P}$} \\
\hline & média & D.P. & média & D.P. & \\
\hline IPTF & 1,23 & 1,09 & 1,83 & 1,77 & 0,0010 \\
\hline DIFIPT & 6,64 & 2,61 & 7,16 & 2,13 & 0,0927 \\
\hline PCIPT & 82,52 & 16,91 & 79,56 & 19,98 & 0,2066 \\
\hline TTRAT - meses & 25,06 & 9,92 & 31,20 & 11,05 & 0,0000 \\
\hline IETIPT & 3,70 & 1,41 & 2,92 & 1,44 & 0,0000 \\
\hline
\end{tabular}



Discussão 



\section{DISCUSSÃO}

Visando proporcionar um melhor entendimento, previamente à discussão dos resultados obtidos, foram discutidas as características da amostra bem como a metodologia aplicada para obtenção dos resultados.

\subsection{A AMOSTRA}

A seleção da amostra foi realizada com o intuito de se avaliar a proporção de sucesso do tratamento sem extração da Classe II em relação à sua severidade inicial. Para tanto, foram selecionados apenas pacientes apresentando má oclusão de $1 / 2$ Classe II e Classe II completa bilateral ${ }^{8,153}$.

Em relação à distinção dos grupos quanto à severidade da Classe II, os pacientes foram selecionados segundo sua relação molar, sendo que, os pacientes com má oclusão de 1⁄2 Classe II apresentavam uma oclusão de cúspide-cúspide, onde a cúspide mesiovestibular do primeiro molar superior fazia contato com a cúspide mesiovestibular do primeiro molar inferior. Os pacientes com Classe II completa apresentavam a cúspide distovestibular do primeiro molar superior ocluindo no sulco vestibular mesial do primeiro molar inferior ${ }^{8,300}$.

Também como critério de inclusão na amostra, os pacientes de um mesmo grupo experimental deveriam apresentar, bilateralmente, a mesma severidade da má oclusão, ou $1 / 2$ Classe II ou Classe II completa. Dessa forma más oclusões classificadas como subdivisões foram excluídas, pois a inclusão destas acarretaria modificações na mecânica empregada, tais como diferentes necessidades por mecânicas assimétricas e, desta forma, influenciando os resultados finais e também 
o tempo de tratamento ${ }^{21}$. Essa característica foi requerida no sentido de padronização dos grupos experimentais em relação à eficiência do tratamento no que diz respeito à correção da relação molar, pois como detalhado mais adiante, primeiramente ANDREWS ${ }^{8}$ em 1975, e depois vários outros pesquisadores $21,49,120,149,152,153,185$, demonstraram que quanto maior for a discrepância da relação molar na Classe II, maiores são as dificuldades de correção dessa má oclusão, e consequentemente maior o tempo despendido no tratamento.

A escolha de somente dois grupos ( $1 / 2$ Classe II e Classe II completa) na realização deste trabalho retrata com maior precisão duas severidades distintas dessa má oclusão, visto que, a discrepância ântero-posterior da relação molar na Classe II completa é duas vezes maior do que essa discrepância na 1/2 Classe II $^{8}$.

Os principais tipos de aparelhos destinados à correção da má oclusão de Classe ${ }^{33}{ }^{33}$ foram considerados neste estudo, não constituindo critérios de exclusão. Sendo assim, pacientes tratados com aparelhos extrabucais (AEB), associados ou não a aparelhos funcionais, e elásticos de Classe II, foram igualmente selecionados, desde que tivessem concluído o tratamento com aparelho fixo. O estabelecimento desta condição permitiu retratar com maior fidelidade os resultados comumente obtidos na correção da Classe II, visto que as mecânicas de Classe II consideradas são as mais freqüentemente utilizadas.

A presença de todos os dentes permanentes, mesmo que não irrompidos, excluindo-se os terceiros molares e a ausência de dentes supranumerários constituiu um critério para inclusão de pacientes na amostra visto que a perda de dentes permanentes, assim como a presença de dentes supranumerários, erupcionados ou não, pode interferir no desenvolvimento normal da oclusão, produzindo más 
oclusões cuja correção exige uma mecânica ortodôntica diferenciada, não contemplando o propósito deste estudo ${ }^{55,209,210}$.

Os casos com anomalias significativas quanto à forma e/ou tamanho dos dentes (macrodente, microdente, dente conóide) foram excluídos uma vez que poderiam aumentar o grau de complexidade do tratamento por uma razão inerente à anatomia dentária e não ao tratamento ortodôntico em $\mathrm{si}^{65,309}$. As pequenas discrepâncias do tamanho dentário, detectadas apenas pela Análise de Bolton, não foram consideradas neste estudo em razão de sua ocorrência não interferir significativamente nos resultados finais ${ }^{139,228}$. Deve-se ressaltar também que a má oclusão de Classe II apresenta a menor prevalência de discrepância do tamanho dentário ${ }^{13}$. Além disso, a ausência de fatores que favoreçam uma maior ocorrência desta discrepância leva a crer que sua incidência entre os grupos estudados é semelhante.

Considerando meticulosamente todos os critérios já mencionados, uma amostra de 277 pacientes (144 do grupo 1 e 133 do grupo 2) foi selecionada a partir da investigação de aproximadamente 4000 documentações ortodônticas provenientes dos registros de arquivo dos cursos de pós-graduação, lato e stricto sensu, e atualização da Disciplina de Ortodontia da Faculdade de Odontologia de Bauru. Admitindo-se que o percentual de incidência da má oclusão de Classe II seja de aproximadamente $30 \%{ }^{221}$, era de se esperar que a amostra selecionada fosse composta por um número bem maior de pacientes. Contudo, deve-se ponderar que os critérios estabelecidos para a seleção da amostra foram responsáveis pela eliminação de um grande número de pacientes com esta má oclusão. Além disso, ressalta-se que a despeito dos esforços empregados para se obter os registros completos de todos os pacientes tratados na Disciplina, alguns deles não 
apresentavam uma documentação ortodôntica condizente com as necessidades específicas deste estudo. Mesmo assim, acredita-se que uma amostra composta de 277 pacientes seja suficiente para a obtenção de resultados fidedignos e que retratem com satisfatória precisão os resultados obtidos do tratamento de dois graus de severidade da má oclusão de Classe II $^{182,199}$.

Os pacientes do grupo 2, apresentando má oclusão de Classe II completa, foram divididos em grupos A e B uma vez que 26 dos 133 pacientes (19,54\%) pertencentes a este grupo tiveram seus tratamentos replanejados após a tentativa frustrada de correção da má oclusão de Classe II sem extrações. A possibilidade de o replanejamento influenciar o tempo do tratamento, além do fato de que as extrações, por si só, já se constituem no insucesso do plano de tratamento inicial, determinou a divisão deste grupo.

Por ser de caráter retrospectivo e por não haver registros das características oclusais dos pacientes na época em que esses tiveram o seu planejamento inicial modificado para extrações de 2 pré-molares superiores, esse estudo apresentaria uma limitação tanto no que diz respeito aos resultados oclusais quanto ao tempo de tratamento. Esses registros oclusais representariam os resultados finais alcançados com o tratamento sem extrações em pacientes pouco colaboradores. Apenas desta forma o grupo de Classe II completa apresentaria resultados reais que seriam provenientes de todos os níveis de colaboração, tal como ocorre no grupo de $1 / 2$ Classe II. O replanejamento de $19,54 \%$ dos pacientes com severidade inicial de Classe II completa fez com que o grupo 2 se transformasse em auto-seletivo, permanecendo para serem tratados apenas os pacientes de melhor colaboração, que constituíram o Grupo 2A. Esta seleção beneficia os resultados do grupo 2A, mascarando a verdadeira diferença de efetividade existente entre as duas 
severidades da má oclusão. Portanto, especula-se que a verdadeira discrepância no grau de eficiência clínica destes dois protocolos de tratamento seja ainda maior do que foi observado neste estudo.

Considerando os fatos acima citados, o menor número de pacientes selecionados para compor o grupo 2A da amostra (107 pacientes) deveu-se ao fato do elevado percentual de pacientes replanejados com extrações de dois pré-molares superiores. Esse fato já indica o maior grau de dificuldade na correção da má oclusão de Classe II completa sem extrações, em relação à $1 / 2$ Classe II. Sendo assim, a quantidade de casos com discrepância ântero-posterior de maior severidade (Classe II completa), submetidos ao protocolo de tratamento sem extrações também tem a tendência de ser menor ${ }^{8,146,300}$. Dessa forma, para a avaliação do sucesso do tratamento desses dois graus de severidades distintos da má oclusão de Classe II, obrigou-se realizar a comparação da porcentagem do número de pacientes que obtiveram sucesso do tratamento em função do número total de paciente de cada grupo.

\subsection{METODOLOGIA}

Segundo LEWIS et al $^{175}$, a melhor forma de avaliação do grau de severidade da má oclusão e do resultado oclusal do seu tratamento consiste na avaliação clínica direta de cada paciente, pois, a proximidade clínica do profissional com o paciente reflete mais completamente a situação da má oclusão e a necessidade de tratamento envolvida nos casos individualizados. Entretanto, esse tipo de avaliação foi praticamente impossível de ser realizada por se tratar de um estudo retrospectivo. O primeiro problema seria entrar em contato com os pacientes, após muitos anos do 
término de seu tratamento. Muitos poderiam ter mudado de endereço, telefone e até de cidade. Mesmo que se conseguisse o comparecimento de um número significante deles, a avaliação do término do tratamento estaria comprometida por possíveis recidivas que tivessem ocorrido ao longo do tempo ou ainda por problemas oclusais ou perdas dentárias subseqüentes ${ }^{178,236,245,259,281-284}$.

A utilização de modelos de estudo como único meio de avaliação das características oclusais do paciente apresenta limitações diagnósticas, privando o profissional das análises clínica e radiográfica. Contudo, este é o registro de estudo que, sozinho, reúne a maior quantidade de informações relacionadas ao diagnóstico e tratamento ortodôntico ${ }^{128}$. Além disso, tem-se demonstrado: 1) uma pobre associação entre as características oclusais observadas em modelos de estudo e a morfologia craniofacial avaliada nas telerradiografias ${ }^{160}$ e 2) uma melhor predição dos resultados do tratamento ortodôntico por meio dos índices oclusais, obtidos dos modelos de estudo pré-tratamento, do que pelas variáveis cefalométricas, medidas nas telerradiografias iniciais ${ }^{163,189}$.

O fato de que a morfologia craniofacial nem sempre reflete as características oclusais, já havia sido evidenciado por PANCHERZ et $\mathrm{al}^{210}$, que observaram características cefalométricas semelhantes ao comparar a Classe II, divisão 1 e 2, contrariando o difundido pensamento de que o maior overbite da má oclusão de Classe II, Divisão 2 está vinculado ao padrão esquelético mais horizontal (hipodivergente) desta má oclusão ${ }^{157}$. Somando-se a estes fatos, ACKERMAN e PROFFIT $^{1}$ em 1997, afirmam que as decisões sobre a estética facial devem seguir o diagnóstico clínico ao invés do cefalométrico.

Portanto, entende-se que a escolha da metodologia a ser empregada deve se basear, impreterivelmente, na proposição do trabalho. Se o propósito maior é avaliar 
as mudanças nas estruturas craniofaciais, então as telerradiografias são indispensáveis, porém se o objetivo se restringe ao estudo das alterações oclusais decorrentes do tratamento, provavelmente a utilização de telerradiografias em norma lateral não trará significativos acréscimos ou elucidações ${ }^{151}$. Além disso, algumas características importantes da oclusão, tais como a quantidade de apinhamento e a relação transversal dos arcos, não poderão sequer, serem avaliadas por este método de investigação ${ }^{45}$.

Deve-se também ressaltar que o caráter retrospectivo deste estudo permitiu que todos os casos fossem selecionados condizentes com os critérios adotados. Portanto, se diferenças existiam entre os valores cefalométricos dos grupos, estas tiveram seus pesos no planejamento do tratamento. Além do mais, não está em discussão o mérito de cada planejamento, mas sim os resultados oclusais proporcionados.

A obtenção de dados mais detalhados sobre a oclusão funcional ao término do tratamento ficou limitada pela característica retrospectiva deste estudo, sendo que as informações a este respeito ativeram-se aos registros constantes nos prontuários. Porém, a constatação de que a montagem em articulador dos modelos iniciais na posição mandibular de relação cêntrica não muda significativamente o planejamento do tratamento ${ }^{92}$, leva a crer que a realização deste mesmo procedimento, ao final do tratamento, não será mais proveitosa do que foi ao início. Além disso, a probabilidade de ocorrência de pequenos desvios funcionais ao final do tratamento tende a ser semelhante entre os grupos, não constituindo um fator de diferenciação entre eles. 
Considerando todos os fatores já mencionados a respeito da metodologia aplicada, admitiu-se que a utilização dos modelos de estudo como material de pesquisa cumpre satisfatoriamente os objetivos deste estudo.

Foi baseado exclusivamente nas informações contidas em 120 modelos de oclusão normal que ANDREWS ${ }^{8}$ relacionou as seis características oclusais que mais freqüentemente ocorriam, definindo-as como as seis chaves da oclusão normal. Este legado passou a representar um dos mais valiosos parâmetros para a obtenção de uma oclusão estática ideal, contudo, o ideal nem sempre é alcançado ao final do tratamento ortodôntico. Sendo assim, a utilização de índices oclusais que mensuram o quanto as relações oclusais desviam da normalidade ao final do tratamento constitui atualmente um importante instrumento de pesquisa sobre a eficácia dos diversos protocolos de tratamento ortodôntico utilizados para um mesmo

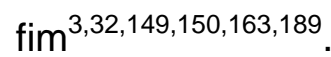

A utilização dos índices oclusais vem sendo muito comentada ${ }^{41,85}$, porém não é amplamente aceita e não existe uma unanimidade sobre eles $32,56,138,167,190,271$. Dos índices propostos na literatura, os mais utilizados são semelhantes e na verdade variações uns dos outros ${ }^{56,265}$. Entre eles um dos mais utilizados recentemente ${ }^{56,122,175,216,265,271}$ é o Índice de Prioridade de Tratamento, proposto por GRAINGER $^{121}$ em 1967, que utiliza uma avaliação oclusal por meio de modelos ortodônticos de gesso. O Índice de Prioridade de Tratamento foi escolhido por ter sido testado em vários estudos e provou ser confiável, com alta correlação nas avaliações clínicas $^{56,175,216}$, consistente na extensão de idade de 3 a 16 anos $^{216}$, altamente reprodutível ${ }^{56}$, correspondendo a muitos dos fatores exigidos pela Organização Mundial da Saúde para índices epidemiológicos ${ }^{269}$. 
Além disso, o índice IPT proporciona uma avaliação criteriosa não apenas dos resultados do tratamento, mas também do grau de severidade da má oclusão ao início do tratamento. Estes atributos permitiram investigar tanto a severidade inicial da má oclusão em cada grupo experimental, quanto a quantidade e o percentual de melhora obtidos em cada grupo ao final do tratamento ${ }^{150}$. Cabe ressaltar também que o processo de obtenção do índice IPT envolve apenas as informações obtidas dos modelos de gesso ${ }^{121}$, haja vista que as avaliações clínicas exigidas em outros índices $^{74,256}$ não condizem com o caráter retrospectivo deste estudo, conforme já foi explicitado. O percentual de melhora, evidenciado pelo índice IPT, foi relacionado ao tempo de tratamento com o intuito de obter um índice capaz de expressar o grau de eficiência do tratamento. Este índice permitiu a mensuração de uma característica do tratamento que é freqüentemente comentada na literatura ${ }^{54,146,192}$, porém raramente avaliada por meio de uma metodologia consagrada, visto que a eficiência do tratamento ortodôntico não se restringe somente à qualidade de finalização.

\subsection{PRECISÃO DA METODOLOGIA}

Muitos autores já formularam conceitos a respeito das características ideais de um índice oclusal apesar de não haver um só índice que as reúna por completo. Conforme mencionado no tópico anterior, o índice oclusal utilizado neste estudo foi selecionado por se adequar melhor à proposição do trabalho. Todas as medições necessárias ao cálculo do índice IPT foram realizadas nos modelos de gesso pré e pós-tratamento com o auxílio de um paquímetro capaz de imprimir às medidas uma precisão de até $0,1 \mathrm{~mm}$. Em seguida, estas medidas foram transformadas em 
escores de acordo com as convenções e normas estabelecidas na publicação original do $\mathrm{IPT}^{121}$.

Para cada par de modelos mensurados obteve-se um total de quatro escores que devidamente somados entre si e à constante condizente à relação molar geraram o valor final do índice IPT. Uma vez que foram avaliados 144 pacientes do Grupo 1 e 107 pacientes do Grupo 2A ao início e final do tratamento ortodôntico, perfazendo 502 pares de modelos, reuniu-se um total de 2008 escores durante este estudo. Considerando, resumidamente, que as medições realizadas nos modelos foram traduzidas em escores e estes somados para a obtenção dos índices, o valor final de cada índice representou com fidelidade todas as medições realizadas nos modelos, tornando-se um parâmetro consistente para a análise do erro da metodologia. Segundo HOUSTON ${ }^{143}$, para que a precisão da metodologia seja analisada adequadamente, um mínimo de 25 casos necessita ser reavaliado. Sendo assim, o cálculo do erro do método foi realizado tomando-se novas medidas e calculando-se um novo índice para 30 pacientes selecionados aleatoriamente de ambos os grupos, contabilizando sessenta pares de modelos iniciais e finais.

Ressalta-se a necessidade de minimizar e controlar os erros operacionais que invariavelmente surgem quando a metodologia envolve medições em telerradiografias ${ }^{26,27,143}$. Embora determinados fatores como a imprecisão na marcação de certos pontos possa agregar às medições radiográficas um maior nível de dificuldade e subjetividade, algum grau de julgamento também pode ocorrer por parte do examinador durante a medição dos modelos e aplicação dos índices oclusais $^{271}$, ressaltando, assim, a importância da análise dos erros metodológicos nestas circunstâncias. 
Segundo HOUSTON ${ }^{143}$, não basta que a metodologia utilizada seja válida para o propósito a que foi requisitada, é necessário que ela seja suficientemente precisa para permitir sua reprodução. Quando esta precisão encontra-se comprometida por algum motivo, surgem os erros que podem ser de natureza sistemática ou casual. Estes erros, quando significativos, afetam a confiabilidade dos resultados, exagerando ou obscurecendo as verdadeiras diferenças entre as variáveis estudadas.

O erro sistemático ocorre quando uma determinada medida é continuamente sub ou superestimada. Se as medições são realizadas por um único examinador este tipo de erro em geral resulta de uma mudança na técnica de mensuração ou de uma tendência subconsciente do examinador em direcionar os resultados de acordo com as próprias expectativas ${ }^{143}$. Por outro lado, HOUSTON ${ }^{143}$ considera que a principal fonte de erros casuais ${ }^{73}$ é representada pela dificuldade e pela imprecisão em identificar ou definir certos pontos. Deve-se ressaltar que estes fatores também podem afetar significativamente a possibilidade de ocorrência dos erros sistemáticos, visto que o examinador pode alterar inadvertidamente a sua técnica de mensuração devido à imprecisão ou falta de padronização da metodologia aplicada.

A ausência de significância dos erros sistemáticos e o reduzido valor dos erros casuais detectados neste estudo decorrem tanto da padronização quanto da precisão das medições, imprimindo uma baixa variabilidade aos valores das medidas utilizadas. Este grau de precisão e padronização talvez possa em grande parte ser explicado pela simplicidade e objetividade com que o índice IPT é aplicado aos modelos de estudo, tornando os resultados bastante confiáveis e facilmente reproduzíveis. Além disso, uma importante contribuição para a redução dos erros 
metodológicos foi a calibração do examinador anteriormente à realização das medidas.

\subsection{RESULTADOS}

Os grupos comparados foram compatíveis quanto ao gênero, tipo de Classe II e fase da dentadura (Tabela 6). Também foram compatíveis em relação à idade inicial do tratamento ortodôntico (Tabela 7). As implicações de cada uma destas variáveis sobre a comparação entre os grupos serão discutidas a seguir.

\subsubsection{Compatibilidade entre os grupos}

\subsubsection{Gênero}

Sabe-se que gêneros diferentes apresentam para uma mesma idade cronológica idades biológicas distintas. Portanto, considerando uma época de maturação mais precoce e um ritmo de crescimento mais acelerado como características de desenvolvimento do gênero feminino, as melhores respostas ao tratamento ortodôntico ocorrem numa idade cronológica menor no gênero feminino do que no masculino $36,39,103,126,148,186,299$. Com essa perspectiva, decidiu-se verificar a compatibilidade entre os grupos $1(1 / 2 \mathrm{CI}$ II) e $2 \mathrm{~A}(\mathrm{Cl}$ II completa) em relação ao gênero.

Além dos gêneros mostrarem diferenças importantes quanto à época de maturação e ritmo de crescimento, produzindo respostas distintas a um mesmo protocolo de tratamento ortodôntico $36,39,103,126,148,186,299$, alguns autores advogam que 
gêneros diferentes podem apresentar níveis distintos de colaboração, beneficiando ou comprometendo as metas do tratamento ${ }^{72,107,264}$.

Considerando que o potencial de crescimento presente é um importante fator na correção da Classe II e que o sucesso dos diversos métodos de correção desta má oclusão dependem, em algum grau, da cooperação do paciente ${ }^{6,22,34,67,78,90,95,98,129,130,150,156,211,300}$, a compatibilidade existente entre os grupos quanto ao gênero foi de grande importância para o controle da influência desta variável sobre os resultados (Tabela 6).

\subsubsection{Tipos de CI II}

Embora a amostra apresente más oclusões de Classe II, divisão 1 e 2, as características oclusais distintas destes dois tipos de más oclusões não comprometeram a compatibilidade dos grupos quanto ao grau de severidade. Isto porque, em geral, o maior escore aplicado ao overjet, nos casos de Classe II, Divisão 1, é quantitativamente compensado pela maior severidade do overbite e apinhamento, observados na Classe II, divisão 2. Esta compensação tende a produzir índices de valores semelhantes, indicando a equivalência dos dois tipos de Classe II quanto ao grau de severidade ${ }^{150}$. Além disso, os grupos mostraram-se compatíveis quanto à distribuição quantitativa dos tipos de Classe II, eliminando, definitivamente, qualquer influência significativa desta variável nos resultados.

\subsubsection{Fase da Dentadura}

Da mesma forma que o gênero e a idade que será discutida logo à seguir, decidiu-se avaliar a compatibilidade dos grupos em relação à fase da dentadura 
(mista ou permanente) baseando-se em mais uma variável capaz de mensurar o estágio de maturação e desenvolvimento do paciente. Dessa maneira, já que é fato que quanto maior o potencial de crescimento do paciente, melhor o prognóstico de correção da má oclusão de Classe II, e que normalmente o paciente que se encontra na fase de dentadura mista apresenta maior potencial de crescimento $14,38,69,83,116,234,262,274,301$ quando comparado ao paciente na fase da dentadura permanente, a compatibilidade dos grupos $1(1 / 2 \mathrm{CI}$ II) e $2 \mathrm{~A}(\mathrm{Cl}$ II completa) em relação à essa variável se tornou extremamente importante para o estudo (Tabela 6).

\subsubsection{Idade inicial}

Sabe-se que a menor média de idade de um grupo ao início do tratamento e, por conseguinte, um maior potencial de crescimento, favorece a correção da má oclusão de Classe $\|^{51,89,129,211,288}$. Se o paciente estiver em crescimento, a probabilidade de sucesso do tratamento da Classe II aumenta consideravelmente porque a atuação dos aparelhos extrabucais de reforço de ancoragem não irão apenas atuar distalizando os dentes superiores, mas também redirecionando o crescimento maxilar, com uma restrição de seu deslocamento para anterior, que auxilia na correção da má oclusão. Adicionalmente, com o crescimento mandibular e seu deslocamento para anterior se processando normalmente, haverá maior probabilidade de correção da discrepância ântero-posterior ${ }^{14,82,129,211,234}$. Neste estudo os grupos mostraram grande compatibilidade em relação à idade inicial (Tabela 7) o que elimina a influência desta variável nos resultados finais. 


\subsubsection{Severidade Inicial}

A avaliação da compatibilidade entre os grupos em relação à severidade inicial da má oclusão foi realizada por meio do teste $t$ não pareado comparando-se o índice de prioridade de tratamento inicial (IPTI) entre os grupos. Os resultados demonstraram que o grupo 2A (Classe II completa) caracterizou-se por apresentar maior severidade da má oclusão ao início do tratamento ortodôntico. Esse resultado era esperado, visto que, o IPT confere grande ênfase à relação molar, pois a decisão pela coluna a ser utilizada na tabela do IPT é definida exclusivamente pela relação molar e adiciona ao escore final do índice uma constante de 2,72 pontos para os casos de $1 / 2$ Classe II bilateral e 5,17 pontos para os casos de Classe II completa bilateral. Desse modo, sabendo-se que a discrepância ântero-posterior da relação molar na Classe II completa é duas vezes maior do que essa discrepância na $1 / 2$ Classe $\| I^{8}$, já era esperado que a severidade da má oclusão inicial do grupo $2 \mathrm{~A}$ fosse realmente maior e pretendido, já que o objetivo final desse trabalho se traduz na avaliação da proporção do sucesso oclusal obtido do tratamento de dois graus de severidade distintos da má oclusão de Classe II.

Assim sendo, verificou-se que a relação molar se constitui de extrema importância para o escore final da severidade da má oclusão e como já especulado na literatura por KING et al $^{165}$, em 2003, a severidade da relação molar de Classe II ao início do tratamento pode ser uma característica confiável para predizer o sucesso do tratamento ortodôntico dessa má oclusão. 


\subsubsection{Resultados oclusais}

\subsubsection{Proporção de Sucesso do Tratamento Ortodôntico}

A variável IPTF foi utilizada para definir o sucesso da correção ortodôntica. Somente foi considerado sucesso do tratamento os casos concluídos com índice satisfatório para final de tratamento. Estabeleceu-se como norma para o sucesso do tratamento, no máximo, 2 pontos para o IPT. Esse limite indicativo de sucesso do

tratamento foi delimitado pelas interpretações de GRAINGER et. al. ${ }^{121}$ e baseandose em trabalhos recentes que relatam o sucesso do tratamento ortodôntico e apresentam os escores do final do tratamento abaixo de 2 pontos ${ }^{150,151}$.

Nesta avaliação foram incluídos os pacientes do Grupo 2B que somados aos pacientes do Grupo 2A constituíram o Grupo 2. Este Grupo foi comparado ao Grupo 1 para analisar a proporção de sucesso do tratamento ortodôntico. É cabível ressaltar que o Grupo 2B somente foi utilizado no estudo para representar a exata quantidade de pacientes que iniciou o tratamento da Classe II completa sem extrações, ao passo que, mesmo sem mensurar a qualidade do resultado oclusal final de seu tratamento, foram automaticamente listados como insucesso ao sofrerem o replanejamento por extrações dentárias.

Desse modo, o Grupo 1 obteve maior percentual de casos finalizados satisfatoriamente (Tabela 8), impondo a condição de que quanto mais severa a má oclusão inicial, menos satisfatórios os resultados oclusais finais da correção ortodôntica, especulados anteriormente por WHEELER et. $\mathrm{al}^{300}$.

Deparando-se com o fato de que a decisão de replanejamento em alguns casos, inicialmente planejados sem extração, poderia ter sido influenciada pela 
expectativa em assegurar resultados oclusais satisfatórios em menor tempo de tratamento, aumentando a eficiência da correção ortodôntica, como já demonstrado por BARROS em $2004^{21}$, nova comparação foi realizada sem o grupo $2 \mathrm{~B}$, ou seja, os grupos 1 e 2A foram avaliados segundo a sua proporção de sucesso do tratamento. O resultado dessa comparação mostrou que os pacientes do grupo 1 obtiveram maior porcentagem de sucesso em relação ao grupo 2A (Tabela 9) o que definitivamente ratifica a idéia que quanto maior é a severidade da Classe II ao início do tratamento ortodôntico, menos satisfatórios são os resultados oclusais ao final do tratamento $^{21,146,300}$.

Os resultados obtidos dessa comparação mencionada acima são de extrema importância, visto que, no momento que houve o replanejamento do tratamento ortodôntico para extrações de 2 pré-molares superiores em 26 dos 133 pacientes inicialmente planejados sem extrações, o grupo 2 transformou-se em auto-seletivo, e somente permaneceram para o tratamento sem extrações, os pacientes de melhor colaboração, que se constituíram no Grupo 2A. Portanto, especula-se que a verdadeira diferença ao comparar-se o sucesso do tratamento entre os grupos 1 e 2A, se compatibilizado o nível de cooperação dos pacientes entre os grupos, seja ainda maior do que foi observado neste estudo.

\subsubsection{Resultado oclusal final e porcentagem de melhora}

Os resultados da comparação entre os grupos em relação ao índice IPT evidenciaram que ao final do tratamento o grupo $1(1 / 2$ Classe II) apresentou as melhores relações oclusais, representada pela variável IPTF (Tabela 7). Considerando que: 1) a amostra foi criteriosamente selecionada; 2) a metodologia 
aplicada foi adequada e suficientemente precisa; 3) os grupos foram compatíveis quanto ao gênero, tipo de Classe II, fase da dentadura e idade do paciente ao início do tratamento ortodôntico, torna-se evidente que a menor severidade da Classe II, observada no Grupo 1, favoreceu a obtenção de melhores resultados oclusais, ao final do tratamento ortodôntico, fazendo com que o percentual de sucesso do tratamento para este grupo fosse melhor $21,146,300$.

Portanto, esses resultados estão relacionados à maior necessidade de cooperação do paciente, uma vez que o tratamento da Classe II sem extrações pressupõe a correção da relação molar, e, desse modo, quanto maior a discrepância ântero-posterior da relação molar, maior a dificuldade de correção da má oclusão e menor a eficiência do tratamento ortodôntico, que será discutida mais adiante ${ }^{78,98,161,290,298}$.

Considerando que os dispositivos ortodônticos destinados à correção da Classe II são em sua grande maioria removíveis e, portanto, dependentes da colaboração do paciente, a qualidade de finalização do tratamento torna-se pouco previsível $^{6,22,34,67,98,150,300}$. Portanto, como a severidade inicial da Classe II está vinculada à necessidade de maior cooperação do paciente durante o tratamento e esta por sua vez é essencial para qualidade da finalização ortodôntica, quanto maior a severidade inicial da má oclusão, maior será a dificuldade para a obtenção de um resultado final satisfatório, sem extrações dentárias, como descrito nesse estudo $^{21,146,300}$.

Segundo ANDREWS ${ }^{8}$, para a correção de cada milímetro de protrusão ou apinhamento são necessárias 2 unidades de espaço (UE), 1 para anterior e 1 para posterior. As unidades de espaço requeridas (UER) podem ser obtidas de diversas formas, sendo que as extrações, desgastes e expansões independem da 
cooperação do paciente e são denominadas Unidades de Espaço Disponíveis (UED). As distalizações e manutenções das unidades de ancoragem são, por excelência, dependentes da colaboração do paciente e, portanto, consideradas como Unidades de Espaço Potenciais (UEP). Sendo assim, numa Classe II completa, os $7 \mathrm{~mm}$ de discrepância ântero-posterior da relação molar, requerem 14 unidades de espaço de cada lado (7 unidades para anterior e 7 unidades para posterior) para serem corrigidos, somando um total de 28 UE que precisam ser obtidas às custas da cooperação do paciente (Unidades de Espaço Potenciais). Já na má oclusão de $1 / 2$ Classe II, existem apenas $3,5 \mathrm{~mm}$ de discrepância da relação molar de cada lado, ou seja, essa má oclusão requer 7 unidades de espaço de cada lado para ser corrigida, somando um total de 14 UE. Sendo assim, o tratamento da má oclusão de Classe II completa requer o dobro da necessidade de colaboração do paciente ao longo do tratamento, quando comparado ao tratamento da $1 / 2$ Classe II. Além disso, o tempo de tratamento também é bem maior, como avaliado mais adiante.

Deve-se salientar que quando o paciente se encontra na fase ativa de crescimento, as Unidades de Espaço Potenciais podem ser mais facilmente obtidas em função das alterações esqueléticas serem somadas às movimentações dentárias, favorecendo, assim, a correção das más oclusões ${ }^{22,54,90,98,130,211}$.

A quantidade de melhora expressada pela variável DIFIPT (Tabela 10) não foi significantemente diferente entre os grupos comparados. Sabe-se que a quantidade de melhora é um valor que apenas quantifica a alteração das variáveis sem considerar o seu valor representativo em relação ao problema inicial, e por isso, tem pouca expressão nesse trabalho. Mesmo assim, a quantidade de melhora foi semelhante entre os grupos estudados. Isso se deveu ao fato do grupo $2 \mathrm{~A}$ partir de 
uma condição oclusal mais severa ao início do tratamento ortodôntico, e, mesmo sendo tratado por mais tempo, não apresentou resultados oclusais semelhantes ao grupo 1 no final do tratamento.

Entretanto, o percentual de melhora é um valor representativo da alteração sofrida pela má oclusão desde o início do tratamento até o final, tomando-se como referência sua condição inicial (proporção de correção). Sendo assim, a correção do tratamento é mais bem representada pelo percentual de melhora ${ }^{32,142}$, uma vez que o cálculo desta variável estabelece uma relação entre a quantidade de melhora e a severidade inicial da má oclusão ${ }^{17}$. No trabalho em questão, a porcentagem de melhora não apresentou diferença significante entre os grupos 1 e $2 \mathrm{~A}$, pois considerando que o grupo 2A (Classe II completa) apresentava inicialmente maior severidade da má oclusão e ao final do tratamento obteve um resultado oclusal menos satisfatório, a porcentagem de melhora manteve-se em níveis similares entre os grupos.

\subsubsection{Tempo de tratamento}

Considerando o presente estudo, o tempo de tratamento total foi maior no grupo que apresentava Classe II completa (Grupo 2A) ao início do tratamento ortodôntico. Estes achados implicam que a correção da má oclusão tem uma menor duração em casos menos severos ${ }^{63,99,201,237,258,272}$, ou como já abordado anteriormente por alguns autores, o maior tempo de tratamento verificado no grupo de Classe II completa deveu-se à impreterível necessidade de se corrigir a relação molar ${ }^{165,237,260,279,290}$. É importante considerar que a duração do tratamento ortodôntico foi comparada entre os grupos 1 e $2 \mathrm{~A}$, ou seja, os pacientes que foram 
submetidos a um replanejamento do tratamento em razão do insucesso do planejamento inicial, previsto sem extrações, foram excluídos dessa comparação. Portanto, especulando-se que houve um gasto desnecessário de tempo na fase inicial do tratamento dos pacientes replanejados, a diferença da duração do tratamento sem extrações de pacientes de 1/2 Classe II e de Classe II completa teria tendência de aumentar se estes fossem incluídos na comparação ${ }^{185}$.

Segundo $\mathrm{ANDREWS}^{8}$, a quantidade de movimentação dentária necessária à correção de um determinado tipo de má oclusão é um fator importante na predição do tempo de tratamento. Portanto, baseando-se no fato do paciente com Classe II completa apresentar a discrepância ântero-posterior da relação molar maior em relação aos pacientes com $1 / 2$ Classe II, é razoável afirmar que as más oclusões com maior severidade inicial exigem maiores graus de colaboração do paciente ${ }^{21}$. Verificando-se que o tratamento da Classe II sem extração é dependente da cooperação do paciente com o uso de elásticos intermaxilares, aparelhos extrabucais e/ou aparelhos funcionais, a correção da relação molar é extremamente dependente da cooperação do paciente, explicando assim a correlação entre a correção da relação molar, uso de AEB e tempo de tratamento, evidenciada por diversos autores $21,29,63,152,185,237,279,290$.

Os trabalhos realizados com o propósito de identificar as diversas variáveis que podem influenciar no tempo de tratamento sugerem que o número de faltas às consultas e quebras dos aparelhos pode alterar 0 tempo de tratamento $^{29,63,99,201,237,258}$. Considerando que estas variáveis apresentam uma mesma probabilidade de ocorrência entre os grupos por serem representativas não apenas do grau de colaboração, mas também das características psicossociais e comportamentais do paciente ${ }^{23,29,63,99,237}$, admitiu-se a compatibilidade dos grupos 
em relação a estes fatores. Além disso, se houvesse alguma tendência dos grupos se diferirem em relação ao grau de colaboração do paciente, seria de se esperar que o maior nível de colaboração ocorresse no grupo $2 \mathrm{~A}$, haja vista que este grupo compreende somente os pacientes que não foram replanejados, ou seja, os pacientes que sofreram alterações no planejamento inicial foram excluídos (Grupo 2B) em função de serem, reconhecidamente, não colaboradores. Mesmo considerando os pacientes do grupo $2 \mathrm{~A}$ mais colaboradores, o tempo de tratamento foi maior para esse grupo o que leva a crer que se compatibilizado o nível de colaboração entre os grupos, a diferença entre o tempo de tratamento seria ainda maior.

Outras variáveis que poderiam influenciar no tempo de tratamento como a presença de dentes impactados, necessidade de cirurgia ortognática e agenesias dentárias foram eliminadas no momento da seleção da amostra.

\subsubsection{A eficiência do tratamento ortodôntico}

Atualmente, o tratamento ortodôntico procura não apenas a obtenção de resultados cada vez melhores, mas também a possibilidade de se alcançá-los num menor intervalo de tempo $29,152,154,185,272$. Esta aspiração representa a busca atual pela eficiência do tratamento.

A eficiência do tratamento ortodôntico não é somente representada pela qualidade satisfatória dos resultados finais. Há a necessidade que essa correção seja obtida num intervalo de tempo que satisfaça às expectativas do profissional e do paciente. Quando se diz que um tratamento foi eficaz, esta afirmação, em geral, não está baseada em nenhuma mensuração ${ }^{54,146,192}$ que possa, de alguma forma, exprimir o grau de eficiência, permanecendo como um parecer subjetivo. A 
aplicação de um índice de eficiência permitiu avaliar e comparar de maneira concreta e objetiva o grau de eficiência da correção das duas severidades da Classe II utilizadas nesse estudo.

A obtenção de um índice de eficiência significativamente maior no Grupo 1 decorreu não apenas dos melhores resultados do tratamento (Tabela 10), mas também do menor tempo despendido para alcançá-los (Tabela 10), ressaltando o maior grau de eficiência no tratamento de más oclusões menos severas (tabela 10).

Sabendo-se que o grupo 2B iniciou o tratamento com o protocolo sem extração, e após certo tempo sofreu o replanejamento, visto a falta de colaboração dos pacientes e a provável impossibilidade de sucesso da correção da má oclusão, é indubitavelmente lúcido desconsiderá-lo da análise do índice de eficiência, visto que, este seria o responsável pelo comprometimento do índice de eficiência de tratamento. Caso este comprometimento não se expressasse no maior tempo despendido no tratamento ortodôntico, impreterivelmente se expressaria na menor qualidade dos resultados oclusais finais ${ }^{258}$.

\subsection{IMPLICAÇÕES CLÍNICAS}

O objetivo primordial desse estudo foi avaliar a proporção de sucesso de dois graus distintos de severidade inicial da má oclusão de Classe II com a intenção de fornecer prognósticos de sucesso de tratamento mais confiáveis para o clínico, na correção das más oclusões de seus pacientes. A maior precisão no prognóstico de sucesso deverá proporcionar tratamentos mais eficientes, ou seja, melhores resultados oclusais em menores tempos de tratamento ortodôntico. 
Conforme foi relatado nesse estudo, pacientes com grande severidade da Classe II (Cl II completa) ao início do tratamento ortodôntico e que foram tratados sem extração, apresentaram resultados oclusais finais menos satisfatórios, além do tempo de tratamento aumentado em relação aos pacientes com menor severidade dessa má oclusão. Esse fato mostra o comprometimento da eficiência do tratamento ortodôntico sem extração dos casos com grande severidade de Classe II, visto que, a eficiência está intimamente relacionada com esses dois fatores descritos acima.

Desse modo, antes de realizar-se a opção pelo tratamento sem extrações de casos de Classe II completa, é imprescindível a avaliação precisa da severidade da má oclusão, pois conforme relatado em outros estudos, nesses casos, a opção por extração de 2 pré-molares superiores promoveria melhores resultados oclusais em menores tempos de tratamento ${ }^{21,153}$. Isto porque as extrações dentárias no arco superior, por si só, já asseguram a correção de metade da discrepância ânteroposterior, independente do grau de cooperação do paciente ${ }^{21,153}$ e o maior tempo de tratamento no protocolo sem extração se origina da necessidade de correção da relação molar ${ }^{152,237,279,290}$, o que não é necessário nos casos com extração de prémolares superiores ${ }^{49,78,149,150,153,161,198,298}$.

Mesmo já existindo uma visualização clínica do menor grau de dificuldade presente na correção da Classe II completa, tratada com extrações de dois primeiros pré-molares superiores $8,49,149,150,152,153,161,168$, muitos casos que poderiam ser satisfatoriamente tratados desta forma, são submetidos a protocolos de tratamento sem extrações, dificultando, quando não, impossibilitando a correção desta má oclusão $^{146,153,300}$.

Sabe-se que quanto mais severa a má oclusão de Classe II, maior deve ser a colaboração do paciente para se obter o sucesso do tratamento ${ }^{146,300}$. O protocolo 
de extrações de 2 pré-molares superiores diminui a necessidade da extrema cooperação do paciente, como já explicado na discussão desse trabalho. Em síntese, o tratamento da Classe II completa com extração de dois pré-molares superiores requer do paciente, aproximadamente, a metade do grau de colaboração previsto nos protocolos de tratamento sem extrações. Esta constatação contribui para explicar a maior eficiência deste protocolo de tratamento nos casos de Classe II completa, produzindo resultados melhores e mais previsíveis ${ }^{21,49,149-153}$.

A recente utilização dos implantes ortodônticos como ancoragem absoluta nos tratamento da Classe II completa com extrações de dois pré-molares superiores tem proporcionado resultados mais previsíveis, visto que o grau de colaboração do paciente não interfere significativamente na obtenção dos objetivos do tratamento $42,53,193,212,297$. Contudo, clinicamente deve-se considerar que a opção pela utilização dos implantes ortodônticos como ancoragem, além de envolverem os riscos e o ônus de uma intervenção cirúrgica, podem estar sujeitos aos insucessos relacionados à estabilidade dos implantes.

O argumento de que o tratamento ortodôntico com extrações causa danos ao perfil, tornando-o excessivamente retruído, tem desestimulado este protocolo de tratamento ${ }^{218,222}$. Contudo, já foi demonstrado que as alterações tegumentares do tratamento com ou sem extrações em pacientes com Classe II são semelhantes ${ }^{106}$. A literatura tem sido unânime em afirmar que os protocolos de tratamento com e sem extrações podem resultar em benefícios ao perfil desde que todas as características do paciente sejam consideradas e um correto planejamento seja realizado $24,35,44,87,308,311$.

Até mesmo a argumentação que a utilização de ancoragem, aparelhos funcionais ou elásticos de Classe II podem evitar a realização de extrações dentárias 
é pouco sustentada, pois o tratamento sem extrações da Classe II, exige um certo grau de distalização de todo o arco superior, aumentando significativamente a probabilidade de impacção dos terceiros molares ${ }^{64,111,223,227}$ cuja remoção cirúrgica envolverá um maior risco ao paciente e ônus ao tratamento do que a extração de dois pré-molares superiores. Por outro lado, extrações realizadas no arco superior poderão favorecer ou, no mínimo, não prejudicar a erupção dos terceiros molares $^{163,223,298}$.

Clinicamente, sabe-se que independente da mecânica utilizada, é extremamente difícil a quantidade de distalização do primeiro molar superior ser suficiente para corrigir toda a discrepância ântero-posterior da relação molar de Classe II completa $^{15}$. Sendo assim, alguma mesialização do molar inferior é necessária. Nos casos em que o paciente apresenta-se na fase ativa de crescimento, a maior quantidade de crescimento mandibular favorecerá significativamente uma maior mesialização do molar inferior em relação ao molar superior, sobretudo se o crescimento maxilomandibular for redirecionado por meio de forças extrabucais e/ou aparelhos funcionais ${ }^{15,54,78,90,95,98,130,156,211}$.

Porém, quando o tratamento da Classe II é realizado numa fase tardia do desenvolvimento, onde o potencial de crescimento é mínimo ou inexistente, a mesialização do molar inferior, necessária à correção da relação molar, dependerá exclusivamente da movimentação dentária, em geral, obtida com o uso de elásticos intermaxilares, requerendo um grau máximo de colaboração do paciente ${ }^{89,129,288}$. Uma vez que o tratamento da má oclusão de Classe II com extração de dois prémolares superiores não intenciona a correção da discrepância ântero-posterior dos molares $^{49,78,149,150,153,161,198,298}$, os objetivos do tratamento podem ser mais facilmente alcançados com um menor grau de colaboração $0^{21,49,149,150,153}$, constituindo, assim o 
protocolo de tratamento mais indicado para pacientes que finalizaram a fase de crescimento com má oclusão de Classe $\|^{21,49,78,153,211,222,298 . ~}$

Dessa forma, chega-se a constatação clínica que casos menos severos de Classe II tratados sem extração apresentam grandes chances de promoverem em tempos menores de tratamento, resultados oclusais finais satisfatórios. Ao passo que em casos de Classe II mais severos (Classe II completa) a abordagem terapêutica com extrações de 2 pré-molares superiores poderia ser a melhor opção de tratamento, economizando assim, o tempo do profissional e principalmente do paciente. Se o tempo de tratamento é mais bem aproveitado, o custo para o paciente e também para o profissional tem a tendência de diminuir. 

Conclusões 



\section{CONCLUSÕES}

De acordo com a metodologia empregada e após análise criteriosa dos resultados é lícito concluir que:

- Houve maior proporção de sucesso do tratamento ortodôntico sem extrações da má oclusão de 1/2 Classe II em comparação à Classe ॥ completa, e;

- O tempo do tratamento ortodôntico foi maior nos pacientes que apresentavam inicialmente ao tratamento, uma Classe II completa;

- O índice de eficiência do tratamento foi maior em pacientes com menor severidade inicial da má oclusão de Classe II. 

Referências 



\section{REFERÊNCIAS}

1. ACKERMAN, JL; PROFFIT, WR. Soft tissue limitations in orthodontics: treatment planning guidelines. Angle Orthod. 1997; 67 (5):327-36.

2. AELBERS, CM; DERMAUT, LR. Orthopedics in orthodontics: Part I, Fiction or reality--a review of the literature. Am J Orthod Dentofacial Orthop. 1996; $110(5): 513-9$.

3. AL YAMI, EA; KUIJPERS-JAGTMAN, AM; VAN 'T HOF, MA. Occlusal outcome of orthodontic treatment. Angle Orthod. 1998; 68 (5):439-44.

4. ALEXANDER, RG; SINCLAIR, PM; GOATES, LJ. Differential diagnosis and treatment planning for the adult nonsurgical orthodontic patient. Am J Orthod. 1986; 89 (2):95-112.

5. ALLAN, TK; HODGSON, EW. The use of personality measurements as a determinant of patient cooperation in an orthodontic pratice. Amer. J. Orthodont. 1968; 54 (6):433-40.

6. ANDERSON, BD. Multiple extraction patterns in severe discrepancy cases. Angle Orthod. 1975; 45 (4):291-303.

7. ANDERSON, GM. On the diagnosis and treatment of "distoclusion". Amer $\mathbf{J}$ Orthod Oral Surg. 1946; 32 (1):88-94.

8. ANDREWS, LF. The straight wire appliance. Syllabus of philosophyand techniques. 2ed. 1975.

9. ANGLE, EH. Classification of malocclusion. Dent. Cosmos. 1899; 41 (3):248-64.

10. ANGLE, EH. Treatment of malocclusion of the teeth. 7.ed. Philadelphia: S.S. White, 1907.

11. ANGLE, EH. The latest and best in orthodontic mechanism. Dent Cosmos. 1928; 70 (12):1143-5.

12. ANGLE, EH. The latest and best in orthodontic mechanism. Dent Cosmos. 1929; $71260-70$.

13. ARAUJO, E; SOUKI, M. Bolton anterior tooth size discrepancies among different malocclusion groups. Angle Orthod. 2003; 73 (3):307-13. 
14. ARVYSTAS, MG. Nonextraction treatment of Class II, Division 1 malocclusions. Am J Orthod. 1985; 88 (5):380-95.

15. ATHERTON, GJ; GLENNY, AM; O'BRIEN, K. Development and use of a taxonomy to carry out a systematic review of the literature on methods described to effect distal movement of maxillary molars. J Orthod. 2002; 29 (3):211-6; discussion 195-6.

16. BACCETTI, T; FRANCHI, L; MCNAMARA, JA, Jr.; TOLLARO, I. Early dentofacial features of Class II malocclusion: a longitudinal study from the deciduous through the mixed dentition. Am J Orthod Dentofacial Orthop. 1997; 111 (5):502-9.

17.BAKER, NJ; DAVID, S; BARNARD, DW; BIRNIE, DJ; ROBINSON, SN. Occlusal outcome in patients undergoing orthognathic surgery with internal fixation. $\mathbf{B r}$ J Oral Maxillofac Surg. 1999; 37 (2):90-3.

18. BALDRIDGE, JP. A study of the relation of the maxillary first permanent molars to the face in Class I and Class II malocclusions. Angle Orthod. 1941; 11 (2):100-9.

19.BALTROMEJUS, S; RUF, S; PANCHERZ, H. Effective temporomandibular joint growth and chin position changes: Activator versus Herbst treatment. A cephalometric roentgenographic study. Eur J Orthod. 2002; 24 (6):627-37.

20.BARRER, JG; GHAFARI, J. Silhouette profiles in the assessment of facial esthetics: a comparison of cases treated with various orthodontic appliances. Am J Orthod. 1985; 87 (5):385-91.

21. BARROS, SEC. Avaliação do grau de eficiência do tratamento da Classe II realizado sem extrações e com extrações de dois pré-molares superiores. Bauru, 2004, 152p. dissertação (mestrado) Universidade de São Paulo.

22. BARTON, S; COOK, PA. Predicting functional appliance treatment outcome in Class II malocclusions--a review. Am J Orthod Dentofacial Orthop. 1997; $112(3): 282-6$.

23. BARTSCH, A; WITT, E; SAHM, G; SCHNEIDER, S. Correlates of objective patient compliance with removable appliance wear. Am J Orthod Dentofacial Orthop. 1993; 104 (4):378-86.

24.BASCIFTCI, FA; USUMEZ, S. Effects of extraction and nonextraction treatment on class I and class II subjects. Angle Orthod. 2003; 73 (1):36-42. 
25.BASS, NM. Orthopedic coordination of dentofacial development in skeletal Class II malocclusion in conjunction with edgewise therapy. Part II. Am J Orthod. 1983; $84(6): 466-90$.

26. BAUMRIND, S; FRANTZ, RC. The reliability of head film measurements. 2 . Conventional angular and linear measures. Am J Orthod. 1971; 60 (5):50517.

27.BAUMRIND, S; FRANTZ, RC. The reliability of head film measurements. 1. Landmark identification. Am J Orthod. 1971; 60 (2):111-27.

28. BAUMRIND, S; KORN, EL; BOYD, RL; MAXWELL, R. The decision to extract: part II. Analysis of clinicians' stated reasons for extraction. Am J Orthod Dentofacial Orthop. 1996; 109 (4):393-402.

29. BECKWITH, FR; ACKERMAN, RJ, Jr.; COBB, CM; TIRA, DE. An evaluation of factors affecting duration of orthodontic treatment. Am J Orthod Dentofacial Orthop. 1999; 115 (4):439-47.

30.BELL, WH; JACOBS, JD; LEGAN, HL. Treatment of Class II deep bite by orthodontic and surgical means. Am J Orthod. 1984; 85 (1):1-20.

31.BERNSTEIN, L; ULBRICH, RW; GIANELLY, AA. Orthopedics versus orthodontics in class II treatment: an implant study. Am J Orthod. 1977; 72 (5):549-59.

32. BIRKELAND, K; FUREVIK, J; BOE, OE; WISTH, PJ. Evaluation of treatment and post-treatment changes by the PAR Index. Eur J Orthod. 1997; 19 (3):27988.

33. BISHARA, SE. Textbook of Orthodontics. Philadelphia: W.B.Saunders Company, 2001. 592 p.

34.BISHARA, SE; ZIAJA, RR. Functional appliances: a review. Am J Orthod Dentofacial Orthop. 1989; 95 (3):250-8.

35. BISHARA, SE; JAKOBSEN, JR. Profile changes in patients treated with and without extractions: assessments by lay people. Am J Orthod Dentofacial Orthop. 1997; 112 (6):639-44.

36. BISHARA, SE; PETERSON, LC; BISHARA, EC. Changes in facial dimensions and relationships between the ages of 5 and 25 years. Am J Orthod. 1984; 85 (3):238-52.

37.BISHARA, SE; CUMMINS, DM; JAKOBSEN, Jr. The morphologic basis for the extraction decision in Class II, Division 1 malocclusions: A comparative study. Am J Orthod Dentofac. Orthop. 1995; 107 (2):129-35. 
38.BISHARA, SE; CUMMINS, DM; ZAHER, AR. Treatment and posttreatment changes in patients with Class II, Division 1 malocclusion after extraction and nonextraction treatment. Am J Orthod Dentofacial Orthop. 1997; 111 (1):1827.

39.BISHARA, SE; JAMISON, JE; PETERSON, LC; DEKOCK, WH. Longitudinal changes in standing height and mandibular parameters between the ages of 8 and 17 years. Am J Orthod. 1981; 80 (2):115-35.

40. BISHARA, SE; JAKOBSEN, J; VORHIES, B; BAYATI, P. Changes in dentofacial structures in untreated Class II division 1 and normal subjects: a longitudinal study. Angle Orthod. 1997; 67 (1):55-66.

41.BJÖRK, A; KREBS, AA; SOLOW, B. A method for epidemiological registration of malocclusion. Acta Odont Scand. 1964; 22 27-41.

42.BLOCK, MS; HOFFMAN, DR. A new device for absolute anchorage for orthodontics. Am J Orthod Dentofacial Orthop. 1995; 107 (3):251-8.

43. BOECLER, PR; RIOLO, ML; KEELING, SD; TENHAVE, TR. Skeletal changes associated with extraoral appliance therapy: an evaluation of 200 consecutively treated cases. Angle Orthod. 1989; 59 (4):263-70.

44.BOWMAN, SJ; JOHNSTON, LE, JR. The esthetic impact of extraction and nonextraction treatments on Caucasian patients. Angle Orthod. 2000; 70 (1):3-10.

45. BRAMBILLA, AC. Comparação dos resultados oclusais do tratamento da Classe II realizado com extrações de dois prémolares, com a terapêutica utilizando as extrações de quatro prémolares. Bauru, 2002, 92 p. Dissertação (Mestrado). Faculdade deOdontologia de Bauru, Universidade de São Paulo.

46. BRANDÃO, AMB; DOMINGUEZ-RODRIGUEZ, GC; CAPELOZZA FILHO, L. Avaliação comparativa entre as características da má oclusão Classe II, divisão 1 obtidas pela cefalometria e análise facial subjetiva. Rev Dental Press Ortod Ortop Fac. 2001; 6 (2):33-40.

47. BROADBENT, BH. A new x-ray technique and its application to ortodontia. Angle Orthod. 1931; $145-66$.

48. BRUSOLA, JAC. Ortodoncia clinica. Barcelona: Salvat Editores, 1989. 509

49.BRYK, C; WHITE, LW. The geometry of Class II correction with extractions. J Clin Orthod. 2001; 35 (9):570-9. 
50.BURDEN, DJ; MCGUINNESS, N; STEVENSON, M; MCNAMARA, T. Predictors of outcome among patients with class II division 1 malocclusion treated with fixed appliances in the permanent dentition. Am $\mathbf{J}$ Orthod Dentofacial Orthop. 1999; $116(4): 452-9$.

51.BUSCHANG, PH; MARTINS, J. Childhood and adolescent changes of skeletal relationships. Angle Orthod. 1998; 68 (3):199-206

52. BUSCHANG, PH; TANGUAY, R; TURKEWICZ, J; DEMIRJIAN, A; LA PALME, L. A polynomial approach to craniofacial growth: description and comparison of adolescent males with normal occlusion and those with untreated Class II malocclusion. Am J Orthod Dentofacial Orthop. 1986; 90 (5):437-42.

53.BYLOFF, FK; KARCHER, H; CLAR, E; STOFF, F. An implant to eliminate anchorage loss during molar distalization: a case report involving the Graz implant-supported pendulum. Int J Adult Orthodon Orthognath Surg. 2000; $15(2): 129-37$.

54. CANGIALOSI, TJ; MEISTRELL, ME, JR.; LEUNG, MA; KO, JY. A cephalometric appraisal of edgewise Class II nonextraction treatment with extraoral force. Am J Orthod Dentofacial Orthop. 1988; 93 (4):315-24.

55. CAPELLUTO, E; LAUWERYNS, I. A simple technique for molar uprighting. $\mathbf{J}$ Clin Orthod. 1997; 31 (2):119-25.

56. CARLOS, JP. Evaluation of indices of malocclusion. Int Dent J. 1970; 20 (4):60617.

57. CARTER, NE. Dentofacial changes in untreated Class II division 1 subjects. $\mathbf{B r} \mathbf{J}$ Orthod. 1987; 14 (4):225-34.

58. CASE, SC. A practical treatise on the technics and principles of dental orthopedia and prosthetic correction of cleft palate. 2. ed. Chicago: 1908.

59. CASE, SC. Principles of retention in orthodontia. Am J Orthod oral Surg. 1920; 3-34.

60. CASE, SC. The question of extraction in orthodontia. Am J Orthod. 1964; 50 (9):660-91.

61. CASSINELLI, AG; FIRESTONE, AR; BECK, FM; VIG, KW. Factors associated with orthodontists' assessment of difficulty. Am J Orthod Dentofacial Orthop. 2003; 123 (5):497-502.

62. CHANG, HF; WU, KM; CHEN, KC; CHENG, MC. Effects of activator treatment on Class II, division 1 malocclusion. J Clin Orthod. 1989; 23 (8):560-3. 
63. CHEW, MT; SANDHAM, A. Effectiveness and duration of two-arch fixed appliance treatment. Aust Orthod J. 2000; 16 (2):98-103.

64. CHIPMAN, RA; KINNERA, R. First- and second-order polarization mode dispersion generated by a two-stage emulator. Appl Opt. 2004; 43 (33):60749.

65. CLAMAN, L; ALFARO, MA; MERCADO, A. An interdisciplinary approach for improved esthetic results in the anterior maxilla. J Prosthet Dent. 2003; 89 (1):1-5.

66. CLEALL, JF; BEGOLE, EA. Diagnosis and treatment of class II division 2 malocclusion. Angle Orthod. 1982; 52 (1):38-60.

67. COLE, WA. Accuracy of patient reporting as an indication of headgear compliance. Am J Orthod Dentofacial Orthop. 2002; 121 (4):419-23.

68. COLENATY, C; GABRIEL, HF. Predicting patient cooperation. J. Clin. Orthodont. 1977; 11 (12):814-19.

69. COZZA, P; DE TOFFOL, L. Functional appliance treatment of severe Class II malocclusion in the early mixed dentition. J Clin Orthod. 2003; 37 (2):69-74.

70. CRAIG, CE. The skeletal patterns characteristic of class I and class II, division I malocclusions in norma lateralis. Angle Orthodont. 1951; 21 (1):44-56.

71. CREEKMORE, TD; RADNEY, LJ. Frankel appliance therapy: orthopedic or orthodontic? Am J Orthod. 1983; 83 (2):89-108.

72. CUCALON, A, 3rd; Smith, RJ. Relationship between compliance by adolescent orthodontic patients and performance on psychological tests. Angle Orthod. 1990; 60 (2):107-14.

73. DAHLBERG, G. Statisticl methods for medical and biological students. New York: Interscience, 1940.

74.DANIELS, C; RICHMOND, S. The development of the index of complexity, outcome and need (ICON). J Orthod. 2000; 27 (2):149-62.

75.DAVIDOVITCH, Z; FINKELSON, MD; STEIGMAN, S; SHANFELD, JL; MONTGOMERY, PC; KOROSTOFF, E. Electric currents, bone remodeling, and orthodontic tooth movement. II. Increase in rate of tooth movement and periodontal cyclic nucleotide levels by combined force and electric current. Am J Orthod. 1980; 77 (1):33-47. 
76. DE CASTRO, N. The challenge of Class II division 1 malocclusion. Am J Orthod. 1960; 46 (11):829-33.

77.DE SATURNO, LD. La duracion del tratamiento ortodoncico y sus condicionantes. Caracas, 1994, 100 tese (prof. titular) Universidad de Caracas.

78.DEANGELIS, V. Selection of teeth for extraction as an adjunct to orthodontic treatment. J Am Dent Assoc. 1973; 87 (3):610-5.

79.DEGUZMAN, L; BAHIRAEI, D; VIG, KW; VIG, PS; WEYANT, RJ; O'BRIEN, K. The validation of the Peer Assessment Rating index for malocclusion severity and treatment difficulty. Am J Orthod Dentofacial Orthop. 1995; 107 (2):1726.

80. DERMAUT, LR; AELBERS, CM. Orthopedics in orthodontics: Fiction or reality. A review of the literature--Part II. Am J Orthod Dentofacial Orthop. 1996; 110 (6):667-71.

81.DEVINCENZO, JP. Changes in mandibular length before, during, and after successful orthopedic correction of Class II malocclusions, using a functional appliance. Am J Orthod Dentofacial Orthop. 1991; 99 (3):241-57.

82. DEWEL, BF. The clinical application of the edgewise appliance in orthodontic treatment. Am J Orthod. 1956; 42 4-28.

83.DEWEL, BF. Class II treatment in the mixed dentition with the Edgewise appliance and extraoral traction. Rep Congr Eur Orthod Soc. 1968; 44 30719.

84.DRAGE, KJ; HUNT, NP. Overjet relapse following functional appliance therapy. Br J Orthod. 1990; 17 (3):205-13.

85. DRAKER, HL. Handicapping labio-lingual deviations: a proposed index for public health purposes. Am J Orthod. 1960; 46 (4):295-305.

86. DRELICH, RC. A cephalometric study of untreated class II, division 1 malocclusion. Angle Orthodont. 1948; 18 (3 -4):70-5.

87.DROBOCKY, OB; SMITH, RJ. Changes in facial profile during orthodontic treatment with extraction of four first premolars. Am J Orthod Dentofacial Orthop. 1989; 95 (3):220-30.

88. DUGONI, SA; LEE, JS. Mixed dentition case report. Am J Orthod Dentofacial Orthop. 1995; 107 (3):239-44. 
89.DYER, GS; HARRIS, EF; VADEN, JL. Age effects on orthodontic treatment: adolescents contrasted with adults. Am J Orthod Dentofacial Orthop. 1991; 100 (6):523-30.

90.EDWARDS, JG. Orthopedic effects with "conventional" fixed orthodontic appliances: a preliminary report. Am J Orthod. 1983; 84 (4):275-91.

91.EGOLF, RJ; BEGOLE, EA; UPSHAW, HS. Factors associated with orthodontic patient compliance with intraoral elastic and headgear wear. Am J Orthod Dentofacial Orthop. 1990; 97 (4):336-48.

92. ELLIS, PE; BENSON, PE. Does articulating study casts make a difference to treatment planning? J Orthod. 2003; 30 (1):45-9; discussion 22-3.

93. EL-MANGOURY, NH. Orthodontic cooperation. Am J Orthod. 1981; 80 (6):604-22.

94. ENLOW, DH; HANS, MG. Essentials of facial growth. Philadelphia: W.B. Sauders, 1996.

95. ENOKI, C; MATSUMOTO, MA; FERREIRA, JT. Orthopedic cervical headgear in class II treatment: case report. Braz Dent J. 2003; 14 (1):63-6.

96. FALTIN, KJ; FALTIN, RM; BACCETTI, T; FRANCHI, L; GHIOZZI, B; MCNAMARA, JA, Jr. Long-term effectiveness and treatment timing for Bionator therapy. Angle Orthod. 2003; 73 (3):221-30.

97. FANNING, RJ. The role of extractions in orthodontic treatment. Int. J. Orthodont. 1964; 2 (1):17-26.

98. FERREIRA, SL. Class II Division 2 deep overbite malocclusion correction with nonextraction therapy and Class II elastics. Am J Orthod Dentofacial Orthop. 1998; 114 (2):166-75.

99. FINK, DF; SMITH, RJ. The duration of orthodontic treatment. Am J Orthod Dentofacial Orthop. 1992; 102 (1):45-51.

100. FISK, GV. The morphology and physiology of distoclusion. Am J Orthod. 1953; $39(1): 3-12$.

101. FISK, RO. When malocclusion concerns the public. J Canad dent Ass. 1960; 26 (7):397-412.

102. FOGLE, LL; SOUTHARD, KA; SOUTHARD, TE; CASKO, JS. Treatment outcomes of growing Class II division I patients with varyng degrees of ânteroposterior and vertical dysplasias, Part I. Cephalometrics. Am J Orthod. Dentofac. Orthop. 2004; 125 (4): 
103. FOLEY, TF; MAMANDRAS, AH. Facial growth in females 14 to 20 years of age. Am J Orthod Dentofacial Orthop. 1992; 101 (3):248-54.

104. FOSTER, TD. A textbook of orthodontics. Oxford: Blackwell Scientific Publications, 1975. 209-23

105. FRANKEL, R. The treatment of Class II, Division 1 malocclusion with functional correctors. Am J Orthod. 1969; 55 (3):265-75.

106. FUSIY, A. Alterações tegumentares do tratamento da má oclusão de Classe II divisão $1 \mathrm{sem}$ e com extrações de pré-molares superiores. Bauru, 2005, Tese (doutorado) Faculdade de Odontologia de Bauru Universidade de São Paulo.

107. GABRIEL, HF. Psychology of the use of the headgear. Angle Orthod. 1965; 35 $(4): 320-5$.

108. GABRIEL, HF. Motivation of the headgear patient. Angle Orthodont. 1968; 38 (2):129-35.

109. GEBECK, TR; MERRIFIELD, LL. Orthodontic diagnosis and treatment analysis-concepts and values. Part I. Am J Orthod Dentofacial Orthop. 1995; 107 (4):434-43.

110. GHAFARI, J; LOCKE, SA; BENTLEY, JM. Longitudinal evaluation of the Treatment Priority Index (TPI). Am J Orthod Dentofacial Orthop. 1989; 96 (5):382-9.

111. GHOSH, J; NANDA, RS. Evaluation of an intraoral maxillary molar distalization technique. Am J Orthod Dentofacial Orthop. 1996; 110 (6):639-46.

112. GIANELLY, AA. One-phase versus two-phase treatment. Am $\mathbf{J}$ Orthod Dentofacial Orthop. 1995; 108 (5):556-9.

113. GIANELLY, AA; VALENTINI, V. The role of "orthopedics" and orthodontics in the treatment of class II, division 1 malocclusions. Am J Orthod. 1976; 69 (6):668-78.

114. GIANELLY, AA; ARENA, SA; BERNSTEIN, L. A comparison of Class II treatment changes noted with the light wire, edgewise, and Frankel appliances. Am J Orthod. 1984; 86 (4):269-76.

115. GRABER, R; NEUMANN, B. Conceito de ortopedia funcional dos maxilares. In: Removable orthodontic appliances. W.B. Saunders; Philadelphia, 1977. p.101-13. 
116. GRABER, TM. Current orthodontic concepts and techniques. Philadelphia: W. B. Saunders Company, 1969. 988

117. GRABER, TM. Maxillary second molar extraction in Class II malocclusion. Am J Orthod. 1969; 56 (4):331-53.

118. GRABER, TM; . Patient motivation. J. Clin. Orthodont. 1971; 5 (12):670-88.

119. GRABER, TM; RAKOSI, T; PETROVIC, AG. Ortpedia dentofacial com aparelhos funcionais. 2 ed. Rio de Janeiro: Guanabara Koogan, 1999. 500

120. GRACIANO, JTA. Características oclusais e cefalométricas de pacientes com Classe II, Divisão 1, tratados com e sem extrações de dois prémolares superiores. Bauru, 2003, 162p. Dissertação - mestrado Faculdade de Odontologia de Bauru, Universidade de São Paulo.

121. GRAINGER, RM. Orthodontic treatment priority index. Washington, D.C.: U.S.Government Printing Office, 1967.

122. GRAY, AS; DEMIRJIAN, A. Indexing occlusions for dental public health programs. Am J Orthod. 1977; 72 (2):191-7.

123. GREWE, JM; HAGAN, DV. Malocclusion indices: a comparative evaluation. Am J Orthod. 1972; 61 (3):286-94.

124. GREWE, JM; HERMANSON, PC. Influence of severity of malocclusion and the duration of orthodontic treatment. Amer. J. Orthodont. 1973; 63 (5):533-6.

125. GURGEL, JA; ALMEIDA, RR; PINZAN, A. Avaliação comparativa das dimensões maxilo-mandibulares entre jovens, do sexo masculino, com má oclusão de Classe II, 1a divisão, não tratados e com oclusão normal. Rev. Dental Press de Ortod. e Ortop. 2000; 5 (2):20-8.

126. HAGG, U; TARANGER, J. Maturation indicators and the pubertal growth spurt. Am J Orthod. 1982; 82 (4):299-309.

127. HAGG, U; DU, X; RABIE, AB. Initial and late treatment effects of headgearHerbst appliance with mandibular step-by-step advancement. Am J Orthod Dentofacial Orthop. 2002; 122 (5):477-85.

128. HAN, UK; VIG, KW; WEINTRAUB, JA; VIG, PS; KOWALSKI, CJ. Consistency of orthodontic treatment decisions relative to diagnostic records. Am $\mathbf{J}$ Orthod Dentofacial Orthop. 1991; 100 (3):212-9. 
129. HARRIS, EF; DYER, GS; VADEN, JL. Age effects on orthodontic treatment: skeletodental assessments from the Johnston analysis. Am J Orthod Dentofacial Orthop. 1991; 100 (6):531-6.

130. HASHIM, HA. Analysis of activator treatment changes. Aust Orthod J. 1991; 12 (2):100-4.

131. HEATH, JR. The nasolabial angle in diagnosis. Aust Orthod J. 1991; 12 (1):55.

132. HELLMAN, M. Studies on the etiology of Angle's Class II malocclusal manifestations. Int J Orthod. 1922; 8 129-59.

133. HENRIQUES, JFC. Estudo cefalométrico comparativo, de três tipos de ancoragem extrabucal, sobre as estruturas dentoesqueléticas, em pacientes com classe II, 1a divisão. Bauru, 1993, 166 Tese (Livredocência) Faculdade de Odontologia de Bauru, Universidade de São Paulo.

134. HENRIQUES, JFC; et. al. Avaliação cefalométrica dos efeitos do ativador combinado à ancoragem extrabucal (tração média) em jovens com má oclusão de classe II, 1a divisão de Angle. Rev. Dental Press de Ortod. Ortop. 1997; 2 (5):77-89.

135. HENRIQUES, JFC; FREITAS, MR; SCAVONE JR, H. Ativador conjugado ao aparelho extrabucal, durante 0 tratamento ortopédico-ortodôntico. Descrição do aparelho e relato de um caso clínico. Ortodontia. 1993; 26 (2):46-56.

136. HENRIQUES, JFC; MALTAGLIATI, LA; PINZAN, A; DE FREITAS, MR. Estudo longitudinal das características da má oclusão de Classe II $1^{a}$ divisão sem tratamento, em jovens brasileiros, leucodermas, por um período médio de 3 anos e 4 meses. Rev. Dental Press Ortod. e Ortop. Facial. 1998; 3 (3):5266.

137. HENRY, RG. The extraction of the four second premolars in orthodontic treatment. Aust Orthod J. 1967; 1 (2):28-32.

138. HERMANSON, PC; GREWE, JM. Examiner Variability of several malocclusions indices. Angle Orthodont. 1970; 40 (3):219-25.

139. HEUSDENS, M; DERMAUT, L; VERBEECK, R. The effect of tooth size discrepancy on occlusion: An experimental study. Am J Orthod Dentofacial Orthop. 2000; 117 (2):184-91.

140. HILL, PA. The prevalence and severity of malocclusion and the need for orthodontic treatment in 9-, 12-, and 15-year-old Glasgow schoolchildren. Br J Orthod. 1992; 19 (2):87-96. 
141. HOFRATH, H. Die bedeutung der roentgenfern und abstandsaufnahmen fur die diagnostik der kiefenanomalien. Fortsch. Orthod. 1931; 2 232-58.

142. HOLMAN, JK; HANS, MG; NELSON, S; POWERS, MP. An assessment of extraction versus nonextraction orthodontic treatment using the peer assessment rating (PAR) index. Angle Orthod. 1998; 68 (6):527-34.

143. HOUSTON, WJB. The analysis of errors in orthodontic measurements. Amer. J. Orthod. 1983; 83 (5):382-90.

144. HOWE, RP. Updating the bonded Herbst appliance. J Clin Orthod. 1983; 17 (2):122-4.

145. HUNTER, CJ. The correlation of facial growth with body height and skeletal maturation at adolescence. Angle Orthod. 1966; 36 (1):44-54.

146. JACOBS, T; SAWAENGKIT, P. National Institute of Dental and Craniofacial Research efficacy trials of bionator class II treatment: a review. Angle Orthod. 2002; 72 (6):571-5.

147. JAKOBSSON, SO. Cephalometric evaluation of treatment effect on Class II, Division I malocclusions. Am J Orthod. 1967; 53 (6):446-57.

148. JAMISON, JE; BISHARA, SE; PETERSON, LC; DEKOCK, WH; KREMENAK, CR. Longitudinal changes in the maxilla and the maxillary-mandibular relationship between 8 and 17 years of age. Am J Orthod. 1982; 82 (3):21730.

149. JANSON, G; DAINESI, EA; HENRIQUES, JF; DE FREITAS, MR; DE LIMA, KJ. Class II subdivision treatment success rate with symmetric and asymmetric extraction protocols. Am J Orthod Dentofacial Orthop. 2003; 124 (3):25764; quiz 339.

150. JANSON, G; BRAMBILLA, AC; HENRIQUES, JF; DE FREITAS, MR; NEVES, LS. Class II treatment success rate in 2- and 4-premolar extraction protocols. Am J Orthod Dentofacial Orthop. 2004; 125 (4):472-9.

151. JANSON, G; DE SOUZA, JE; DE FREITAS, MR; HENRIQUES, JF; CAVALCANTI, CT. Occlusal changes of Class II malocclusion treatment between Frankel and the eruption guidance appliances. Angle Orthod. $2004 ; 74$ (4):521-5.

152. JANSON, G; MARIA, FR; BARROS, SE; FREITAS, MR; HENRIQUES, JF. Orthodontic treatment time in 2- and 4-premolar-extraction protocols. Am J Orthod Dentofacial Orthop. 2006; 129 (5):666-71. 
153. JANSON, G; GRACIANO, JTA; HENRIQUES, JF; FREITAS, MR; PINZAN, A; PINZAN-VERCELINO, CRM. Occlusal and cephalometric Class II division 1 malocclusion severity in patients treated with and without extraction of two maxillary premolars. Am. J. Orthod. Dentofac. Orthop. 2006; 129 (6):759-67.

154. JARVINEN, S; WIDSTROM, E; RAITIO, M. Factors affecting the duration of orthodontic treatment in children. A retrospective study. Swed Dent J. 2004; $28(2): 93-100$.

155. JOHNSTON, LE, Jr. Functional appliances: a mortgage on mandibular position. Aust Orthod J. 1996; 14 (3):154-7.

156. JOHNSTON, LE, Jr. Growth and the Class II patient: rendering unto Caesar. Semin Orthod. 1998; 4 (1):59-62.

157. KARLSEN, AT. Craniofacial morphology in children with Angle Class II-1 malocclusion with and without deepbite. Angle Orthod. 1994; 64 (6):437-46.

158. KARLSEN, AT; KROGSTAD, O. Morphology and growth in convex profile facial patterns: a longitudinal study. Angle Orthod. 1999; 69 (4):334-44.

159. KEELING, SD; WHEELER, TT; KING, GJ; GARVAN, CW; COHEN, DA; CABASSA, S; MCGORRAY, SP; TAYLOR, MG. Anteroposterior skeletal and dental changes after early Class II treatment with bionators and headgear. Am J Orthod Dentofacial Orthop. 1998; 113 (1):40-50.

160. KEIM, RG; GOTTLIEB, EL; NELSON, AH; VOGELS, DS, 3rd. 2002 JCO study of orthodontic diagnosis and treatment procedures. Part 1. Results and trends. J Clin Orthod. 2002; 36 (10):553-68.

161. KESSEL, SP. The rationale of maxillary premolar extraction only in Class II therapy. Am J Orthod. 1963; 49 (4):276-93.

162. KIGELE, E. Cephalometric changes from activator-headgear treatment of Class II, division 1 malocclusion. J Clin Orthod. 1987; 21 (7):466-9.

163. KIM, JC; MASCARENHAS, AK; JOO, BH; VIG, KW; BECK, FM; VIG, PS. Cephalometric variables as predictors of Class II treatment outcome. Am J Orthod Dentofacial Orthop. 2000; 118 (6):636-40.

164. KING, EW. Variations in profile changes and their significance in time treatment. Angle Orthod. 1960; 30 (3):141-53.

165. KING, GJ; MCGORRAY, SP; WHEELER, TT; DOLCE, C; TAYLOR, M. Comparison of peer assessment ratings (PAR) from 1-phase and 2-phase treatment protocols for Class II malocclusions. Am J Orthod Dentofacial Orthop. 2003; 123 (5):489-96. 
166. KING, TB. A cephalometric study of the positional relationship of the incisors and apical bases to each other in Class I and Class II, division 1. Amer J Orthodont. 1962; 48 (8):629-30.

167. KINNAN, BK; BURKE, PH. Quantitative assesment of the occlusal features. Brit. J. Orthodont. 1981; 8 (3):149-56.

168. KLAPPER, L; NAVARRO, SF; BOWMAN, D; PAWLOWSKI, B. The influence of extraction and nonextraction orthodontic treatment on brachyfacial and dolichofacial growth patterns. Am J Orthod Dentofacial Orthop. 1992; 101 (5):425-30.

169. KLOCKE, A; NANDA, RS; KAHL-NIEKE, B. Skeletal Class II patterns in the primary dentition. Am J Orthod Dentofacial Orthop. 2002; 121 (6):596-601.

170. KLOEHN, SJ. Guiding alveolar growth and eruption of teeth to reduce treatment time and produce a more balanced denture and face. AngleOrthodont. $1947 ; 17(1-2): 10-33$.

171. KLUEMPER, GT; BEEMAN, CS; HICKS, EP. Early orthodontic treatment: what are the imperatives? J Am Dent Assoc. 2000; 131 (5):613-20.

172. LAGERSTROM, LO; NIELSEN, IL; LEE, R; ISAACSON, RJ. Dental and skeletal contributions to occlusal correction in patients treated with the high-pull headgear-activator combination. Am J Orthod Dentofacial Orthop. 1990; 97 (6):495-504.

173. LAMARQUE, S. The importance of occlusal plane control during orthodontic mechanotherapy. Am J Orthod Dentofacial Orthop. 1995; 107 (5):548-58.

174. LEVIN, RI. Activator headgear therapy. Am J Orthod. 1985; 87 (2):91-109.

175. LEWIS, EA; ALBINO, JE; CUNAT, JJ; TEDESCO, LA. Reliability and validity of clinical assessments of malocclusion. Am J Orthod. 1982; 81 (6):473-7.

176. LIEBERMAN, AM; GAZIT, EJ. Guides to orthodontic treatment timing. Am Dent Assoc. 1974; $88(3): 555-62$.

177. LITT, RA; NIELSEN, IL. Class II, division 2 malocclusion. To extract--or not extract? Angle Orthod. 1984; 54 (2):123-38.

178. LITTLE, RM; WALLEN, TR; RIEDEL, RA. Stability and relapse of mandibular anterior alignment-first premolar extraction cases treated by traditional edgewise orthodontics. Am J Orthod. 1981; 80 (4):349-65. 
179. LIVIERATOS, FA; JOHNSTON, LE, Jr. A comparison of one-stage and twostage nonextraction alternatives in matched Class II samples. Am J Orthod Dentofacial Orthop. 1995; 108 (2):118-31.

180. LUECKE, PE, 3rd; JOHNSTON, LE, Jr. The effect of maxillary first premolar extraction and incisor retraction on mandibular position: testing the central dogma of "functional orthodontics". Am J Orthod Dentofacial Orthop. 1992; $101(1): 4-12$.

181. LUEDTKE, GL. Preventive orthodontics: early reduction of Class II, Division 1 malocclusion. Am J Orthod. 1973; 63 (1):18-29.

182. MACFARLANE, TV. Sample size determination for research projects. J Orthod. 2003; 30 (2):99-100.

183. MACHEN, DE. Risk management. Additional fee in case of non-cooperation in orthodontics. J Clin Orthod. 1995; 29 (1):29-30.

184. MALTAGLIATI, LA et. al. Avaliação cefalométrica comparativa da má oclusão de Classe II, 1a divisão, tratada com ortopedia mecânica e com terapia ortodôntica fixa sem extrações. Ortodontia. 1998; 31 (1):30-44.

185. MARIA, FRT. Estudo do tempo de tratamento de casos tratados ortodonticamente com extrações de dois pré-molares superiores comparados aos de extrações de quatro pré-molares. Bauru, 2002, 111 p. Dissertação (Mestrado) Faculdade de Odontologia de Bauru, Universidade de São Paulo.

186. MARTINS, DR, et al. Atlas de crescimento craniofacial. Bauru: Santos, 1998. $280 \mathrm{p}$.

187. MCCALL, JO. A study of malocclusion in pre-school and school children. Dent Items Interest. 1944; 131-3.

188. MCCULLOUGH, S. Angle Class II, division 1 malocclusion treated without premolar extraction. Am J Orthod Dentofacial Orthop. 1994; 106 (3):317-21.

189. MCGUINNESS, NJ; MCDONALD, JP. The influence of operator changes on orthodontic treatment times and results in a postgraduate teaching environment. Eur J Orthod. 1998; 20 (2):159-67.

190. MCKNIGHT, MM; DANIELS, CP; JOHNSTON, LE, Jr. A retrospective study of two-stage treatment outcomes assessed with two modified PAR indices. Angle Orthod. 1998; 68 (6):521-4; discussion 25-6.

191. MCNAMARA Jr., JA. Components of class II malocclusion in children 8-10 years of age. Angle Orthod. 1981; 51 (3):177-202. 
192. MELSEN, B; BOSCH, C. Different approaches to anchorage: a survey and an evaluation. Angle Orthod. 1997; 67 (1):23-30.

193. MIYAWAKI, S; KOYAMA, I; INOUE, M; MISHIMA, K; SUGAHARA, T; TAKANOYAMAMOTO, T. Factors associated with the stability of titanium screws placed in the posterior region for orthodontic anchorage. Am $\mathbf{J}$ Orthod Dentofacial Orthop. 2003; 124 (4):373-8.

194. MOORE, AW. Orthodontic treatment factors in Class II malocclusion. Amer. J. Orthodont. 1959; 45 (5):323-52.

195. MOYERS, RE; RIOLO, ML; GUIRE, KE; WAINRIGHT, RL; BOOKSTEIN, FL. Differential diagnosis of class II malocclusions. Part 1. Facial types associated with class II malocclusions. Am J Orthod. 1980; 78 (5):477-94.

196. MUSICH, DR. Orthodontics and orthognathic surgery: principles of combined treatment. In: GRABER, TM; VANARSDALL, R. Orthodontics: current principles and techniques. St. Louis, Mosby, 1994.

197. NANDA, RS; KIERL, MJ. Prediction of cooperation in orthodontic treatment. Am J Orthod Dentofacial Orthop. 1992; 102 (1):15-21.

198. NANGIA, A; DARENDELILER, MA. Finishing occlusion in Class II or Class III molar relation: therapeutic Class II and III. Aust Orthod J. 2001; 17 (2):8994.

199. NEWCOMBE, RG. Statistical applications in orthodontics. Part III. How large a study is needed? J Orthod. 2001; 28 (2):169-72.

200. NORTHCUTT, ME; . The timing headgear. J. Clin. Orthodont. 1974; 8 321-4.

201. O'BRIEN, KD; ROBBINS, R; VIG, KW; VIG, PS; SHNORHOKIAN, H; WEYANT, $R$. The effectiveness of Class II, division 1 treatment. Am $\mathbf{J}$ Orthod Dentofacial Orthop. 1995; 107 (3):329-34.

202. O'NEILL, K; HARKNESS, M; KNIGHT, R. Ratings of profile attractiveness after functional appliance treatment. Am J Orthod Dentofacial Orthop. 2000; 118 (4):371-6; discussion 77.

203. OPPENHEIM, A. Prognathism from the anthopological and orthodontic viewpoints. Dent. Cosmos. 1928; 70 (12):1170-84.

204. ORGANIZATION, WH. An international methodology for epidemiological studies of oral disease. Geneva: 1966. 
205. OZTURK, Y; TANKUTER, N. Class II: a comparison of activator and activator headgear combination appliances. Eur J Orthod. 1994; 16 (2):149-57.

206. PAE, EK; MCKENNA, GA; SHEEHAN, TJ; GARCIA, R; KUHLBERG, A; NANDA, R. Role of lateral cephalograms in assessing severity and difficulty of orthodontic cases. Am J Orthod Dentofacial Orthop. 2001; 120 (3):25462.

207. PANCHERZ, H. The nature of Class II relapse after Herbst appliance treatment: a cephalometric long-term investigation. Am J Orthod Dentofacial Orthop. $1991 ; 100$ (3):220-33.

208. PANCHERZ, H. Dentofacial orthopedics or orthognathic surgery: is it a matter of age? Am J Orthod Dentofacial Orthop. 2000; 117 (5):571-4.

209. PANCHERZ, H; FISCHER, S. Amount and direction of temporomandibular joint growth changes in Herbst treatment: a cephalometric long-term investigation. Angle Orthod. 2003; 73 (5):493-501.

210. PANCHERZ, H; ZIEBER, K; HOYER, B. Cephalometric characteristics of Class II division 1 and Class II division 2 malocclusions: a comparative study in children. Angle Orthod. 1997; 67 (2):111-20.

211. PAQUETTE, DE; BEATTIE, JR; JOHNSTON, LE, Jr. A long-term comparison of nonextraction and premolar extraction edgewise therapy in "borderline" Class II patients. Am J Orthod Dentofacial Orthop. 1992; 102 (1):1-14.

212. PARK, HS; KWON, TG. Sliding mechanics with microscrew implant anchorage. Angle Orthod. 2004; 74 (5):703-10.

213. PFEIFFER, JP. Should orthopaedic treatment of severe class II malocclusions be related to growth? Eur J Orthod. 1980; 2 (4):249-56.

214. PFEIFFER, JP; GROBETY, D. Simultaneous use of cervical appliance and activator: an orthopedic approach to fixed appliance therapy. Am J Orthod. $1972 ; 61(4): 353-73$.

215. PFEIFFER, JP; GROBETY, D. The class II malocclusion: differential diagnosis and clinical application of activators, extraoral traction, and fixed appliances. Am J Orthod. 1975; 68 (5):499-544.

216. POPOVICH, F; THOMPSON, GW. A longitudinal comparison of the orthodontic treatment priority index and the subjective appraisal of the orthodontist. $\mathbf{J}$ Public Health Dent. 1971; 31 (1):2-8. 
217. PROFFIT, WR. Orthodontic treatment planning: limitations and special problems. In: Contemporany orthodontics. 2.ed., St. Louis, Mosby year book, 1993. p.225-64.

218. PROFFIT, WR. Forty-year review of extraction frequencies at a university orthodontic clinic. Angle Orthod. 1994; 64 (6):407-14.

219. PROFFIT, WR; ACKERMAN, JL. Rating the characteristics of malocclusion: a systematic approach for planning treatment. Am J Orthod. 1973; 64 (3):25869.

220. PROFFIT, WR; TULLOCH, JF. Preadolescent Class II problems: treat now or wait? Am J Orthod Dentofacial Orthop. 2002; 121 (6):560-2.

221. PROFFIT, WR; FIELDS, HW, Jr.; MORAY, LJ. Prevalence of malocclusion and orthodontic treatment need in the United States: estimates from the NHANES III survey. Int J Adult Orthodon Orthognath Surg. 1998; 13 (2):97-106.

222. PROFFIT, WR; PHILLIPS, C; TULLOCH, JF; MEDLAND, PH. Surgical versus orthodontic correction of skeletal Class II malocclusion in adolescents: effects and indications. Int $\mathbf{J}$ Adult Orthodon Orthognath Surg. 1992; 7 (4):209-20.

223. PUTRICK, LM. Presença clínica e angulação dos terceiros molares superiores, na má oclusão de Classe II, tratada com e sem extrações de pré-molares superiores. Bauru, 2003, 74 p Dissertação (Mestrado) Faculdade de Odontologia de Bauru, Universidade de São Paulo.

224. RABIE, AB; SHE, TT; HAGG, U. Functional appliance therapy accelerates and enhances condylar growth. Am J Orthod Dentofacial Orthop. 2003; 123 (1):40-8.

225. RABIE, AB; LEUNG, FY; CHAYANUPATKUL, A; HAGG, U. The correlation between neovascularization and bone formation in the condyle during forward mandibular positioning. Angle Orthod. 2002; 72 (5):431-8.

226. RANIERI, WA. Innovations in Class II orthodontic correction. N Y St dent J. $1994 ; 60(5): 40-2$.

227. RAPE, WG; JACOBSON, A. Nonextraction treatment of a Class II, division 1 malocclusion. Am J Orthod Dentofacial Orthop. 1993; 103 (2):99-106.

228. REDAHAN, S; LAGERSTROM, L. Orthodontic treatment outcome: the relationship between anterior dental relations and anterior inter-arch tooth size discrepancy. J Orthod. 2003; 30 (3):237-44. 
229. REDDY, P; KHARBANDA, OP; DUGGAL, R; PARKASH, H. Skeletal and dental changes with nonextraction Begg mechanotherapy in patients with Class II Division 1 malocclusion. Am J Orthod Dentofacial Orthop. 2000; 118 (6):641-8.

230. RICHMOND, S; SHAW, WC; STEPHENS, CD. Orthodontics in the General Dental Services of England and Wales: the provision of treatment. Br Dent J. 1992; $172(4): 150-2$.

231. RICHMOND, S; ANDREWS, M; ROBERTS, CT. The provision of orthodontic care in the general dental services of England and Wales: extraction patterns, treatment duration, appliance types and standards. $\mathbf{B r} \mathbf{J}$ Orthod. 1993; $20(4): 345-50$.

232. RICHMOND, S; SHAW, WC; ROBERTS, CT; ANDREWS, M. The PAR Index (Peer Assessment Rating): methods to determine outcome of orthodontic treatment in terms of improvement and standards. Eur J Orthod. 1992; 14 (3):180-7.

233. RICHMOND, S; SHAW, WC; O'BRIEN, KD; BUCHANAN, IB; JONES, R; STEPHENS, CD; ROBERTS, CT; ANDREWS, M. The development of the PAR Index (Peer Assessment Rating): reliability and validity. Eur J Orthod. $1992 ; 14$ (2):125-39.

234. RICKETTS, RM. The influence of orthodontic treatment on facial growth and development. Angle Orthod. 1960; 30 103-33.

235. RIEDEL, RA. The relation of maxillary structures to cranium in malocclusion and in normal occlusion. Angle Orthodont. 1952; 22 (3):142-5.

236. RIEDEL, RA; BRANDT, S. Dr. Richard A. Riedel on retention and relapse. J Clin Orthod. 1976; $10(6): 454-72$.

237. ROBB, SI; SADOWSKY, C; SCHNEIDER, BJ; BEGOLE, EA. Effectiveness and duration of orthodontic treatment in adults and adolescents. Am J Orthod Dentofacial Orthop. 1998; 114 (4):383-6.

238. ROCCO, TD. Thoughts on stripping of anterior teeth. J. Clin. Orthodont. 1971; $5(9): 510-11$.

239. RONDEAU, BH. Class II malocclusion in mixed dentition. J Clin Pediatr Dent. $1994 ; 19(1): 1-11$.

240. ROSENBLUM, RE. Class II malocclusion: mandibular retrusion or maxillary protrusion? Angle Orthod. 1995; 65 (1):49-62. 
241. RUBIN, RM. Comments on high angle Class II cases. Am J Orthod Dentofacial Orthop. 1992; 101 (3):22A-24A.

242. SAHM, G; BARTSCH, A; Witt, E. Reliability of patient reports on compliance. Eur J Orthod. 1990; 12 (4):438-46.

243. SALZMAN, JA. Criteria for extraction in orthodontic therapy related to dentofacial development. Am. J. Orthod. 1949; 35 584-610.

244. SALZMANN, JA. Factors in successful orthodontic therapy before and after using appliances. Amer. J. Orthodont. 1963; 49 (2):581-87.

245. SALZMANN, JA. An evaluation of retention and relapse following orthodontic therapy. Am J Orthod. 1965; 51 (10):779-81.

246. SALZMANN, JA. Practice of orthodontics. Philadelphia: Lippincott Company, 1966.

247. SASSOUNI, V. A classification of skeletal facial types. Am J Orthod. 1969; 55 (2):109-23.

248. SASSOUNI, V. The Class II syndrome: differential diagnosis and treatment. Angle Orthod. 1970; 40 (4):334-41.

249. SCHAEFER, AT; MCNAMARA, JA, Jr.; FRANCHI, L; BACCETTI, T. A cephalometric comparison of treatment with the Twin-block and stainless steel crown Herbst appliances followed by fixed appliance therapy. Am J Orthod Dentofacial Orthop. 2004; 126 (1):7-15.

250. SCHUDY, FF. The Rotation of the Mandible Resulting from Growth: Its Implications in Orthodontic Treatment. Angle Orthod. 1965; 35 36-50.

251. SCHUTZ-FRANSSON, U; BJERKLIN, K; KUROL, J. Mandibular incisor stability after bimaxillary orthodontic treatment with premolar extraction in the upper arch. J Orofac Orthop. 1998; 59 (1):47-58.

252. SCLARE, R. Orthodontics and school children: a survey of 680 children. Brit dent J. 1945; 79 278-80.

253. SEÇHIN, Ö; SURUCU, R. Treatment of class II, division 1 cases with a maxillary traction splint. Quintessence Int. 1990; 21 (3):209-15.

254. SERVOSS, JM. Classification of occlusion. J Dent Child. 1975; 42 (1):28-30. 
255. SHAW, WC; RICHMOND, S; O'BRIEN, KD. The use of occlusal indices: a European perspective. Am J Orthod Dentofacial Orthop. 1995; 107 (1):110.

256. SHAW, WC; RICHMOND, S; O'BRIEN, KD; BROOK, P; STEPHENS, CD. Quality control in orthodontics: indices of treatment need and treatment standards. Br Dent J. 1991; 170 (3):107-12.

257. SHEIHAM, A; HOBDELL, MH; VIG, P; GRIFFITHS, PJ. Orthodontic treatment in the general dental service in England and Wales. A study. Br Dent J. 1971; $131(12): 535-8$.

258. SHIA, GJ. Treatment overruns. J Clin Orthod. 1986; 20 (9):602-4.

259. SHIELDS, TE; LITTLE, RM; CHAPKO, MK. Stability and relapse of mandibular anterior alignment: a cephalometric appraisal of first-premolar-extraction cases treated by traditional edgewise orthodontics. Am J Orthod. 1985; 87 (1):27-38.

260. SKIDMORE, KJ; BROOK, KJ; THOMSON, WM; HARDING, WJ. Factors influencing treatment time in orthodontic patients. Am J Orthod Dentofacial Orthop. 2006; 129 (2):230-8.

261. SLAKTER, MJ; ALBINO, JE; FOX, RN; LEWIS, EA. Reliability and stability of the orthodontic Patient Cooperation Scale. Am J Orthod. 1980; 78 (5):55963.

262. SPENGEMAN, WG. The advantages of early (mixed dentition) treatment in class I and class II protrusion cases. Dent Clin North Am. 1968; 529-40.

263. STALLARD, H. The general prevalence of gross symptoms of malocclusion. Dent Cosmos. 1932; 74 29-37.

264. STARNBACH, HK; KAPLAN, A. Profile of an excellent orthodontic patient. Angle Orthod. 1975; 45 (2):141-5.

265. STEIGMAN, S; KAWAR, M; ZILBERMAN, Y. Prevalence and severity of malocclusion in Israeli Arab urban children 13 to 15 years of age. Am $\mathbf{J}$ Orthod. 1983; 84 (4):337-43.

266. STEYN, CL; DU PREEZ, RJ; HARRIS, AM. Differential premolar extractions. Am J Orthod Dentofacial Orthop. 1997; 112 (5):480-6.

267. STEYN, CL; MARITZ, JS; DU PREEZ, RJ; HARRIS, AM. Facial profile changes with various orthodontic premolar extraction sequences during growth. Sadj. 2004; 59 (4):139-41, 43-5. 
268. STRANG, RHW. Tratado de ortodoncia. Editorial Bibliográfica Argentina. Buenos Aires: 1957. 567-70

269. SUMMERS, CJ. The occlusal index: a system for identifying and scoring occlusal disorders. Am J Orthod. 1971; 59 (6):552-67.

270. SWETLIK, WP. A behavioral evaluation of patient cooperation in the use of extraoral elastic and coil spring traction devices. Amer. J. Orthodont. 1978; 74687.

271. TANG, EL; WEI, SH. Recording and measuring malocclusion: a review of the literature. Am J Orthod Dentofacial Orthop. 1993; 103 (4):344-51.

272. TAYLOR, PJ; KERR, WJ; MCCOLL, JH. Factors associated with the standard and duration of orthodontic treatment. Br J Orthod. 1996; 23 (4):335-41.

273. TERRY, HK. The labiolingual appliance. Am J Orthod. 1969; 55 (6):714-33.

274. TSAMTSOURIS, A; VEDRENNE, D. The use of the bionator appliance in the treatment of Class II, division 1 malocclusion in the late mixed dentition. $\mathbf{J}$ Pedod. 1983; 8 (1):78-104.

275. TULLEY, WJ; CAMPBELL, AC. A manual of practical orthodontics. Bristol: John Wright and Sons, 1965.

276. TULLOCH, JF; PHILLIPS, C; PROFFIT, WR. Benefit of early Class II treatment: progress report of a two-phase randomized clinical trial. Am J Orthod Dentofacial Orthop. 1998; 113 (1):62-72, quiz 73-4.

277. TULLOCH, JF; PROFFIT, WR; PHILLIPS, C. Outcomes in a 2-phase randomized clinical trial of early Class II treatment. Am J Orthod Dentofacial Orthop. 2004; 125 (6):657-67.

278. TULLOCH, JF; PHILLIPS, C; KOCH, G; PROFFIT, WR. The effect of early intervention on skeletal pattern in Class II malocclusion: a randomized clinical trial. Am J Orthod Dentofacial Orthop. 1997; 111 (4):391-400.

279. TURBILL, EA; RICHMOND, S; WRIGHT, JL. The time-factor in orthodontics: what influences the duration of treatments in National Health Service practices? Community Dent Oral Epidemiol. 2001; 29 (1):62-72.

280. TURNER, SA. Occlusal indices revisited. Br J Orthod. 1990; 17 (3):197-203. 
281. TWEED, $\mathrm{CH}$. The application of the principles of the edgewise arch in the treatment of Class II, division 1 malocclusion: part 2. Angle Orthod. 1936; 6 255-7.

282. TWEED, $\mathrm{CH}$. The application of the principles of the edgewise arch in the treatment of Class II, Division 1 malocclusion: part. 1. Angle Orthod. 1936; 6 198-208.

283. TWEED, $\mathrm{CH}$. The application of the edgewise arch in the treatment of malocclusions: Part II. Angle Orthod. 1941; 11 (1):12-67.

284. TWEED, $\mathrm{CH}$. The application of the principles of the edgewise arch in the treatment of malocclusions: Part I. Angle Orthod. 1941; 11 (1):5-11.

285. TWEED, CH. The Frankfort mandibular incisor angle (FMIA) in orthodontic diagnosis, treatment planning and prognosis. Angle Orthodont. 1954; 24 (3):121-69.

286. VADEN, JL. Sequential directional forces treatment: two Class II case reports. Am J Orthod Dentofacial Orthop. 1991; 99 (6):491-504.

287. VADEN, JL; KISER, HE. Straight talk about extraction and nonextraction: a differential diagnostic decision. Am J Orthod Dentofacial Orthop. 1996; $109(4): 445-52$.

288. VADEN, JL; HARRIS, EF; BEHRENTS, RG. Adult versus adolescent Class II correction: a comparison. Am J Orthod Dentofacial Orthop. 1995; 107 (6):651-61.

289. VAN KIRK JR., LE; PENNEL, EH. Assesment of malocclusion in population groups. Am J Orthod. 1959; 45 (10):752-8.

290. VIG, KW; WEYANT, R; VAYDA, D; O'BRIEN, K; BENNETT, E. Orthodontic process and outcome: efficacy studies--strategies for developing process and outcome measures: a new era in orthodontics. Clin Orthod Res. 1998; $1(2): 147-55$.

291. VIG, PS; VIG, KD. Decision analysis to optimize the outcomes for Class II Division 1 orthodontic treatment. Semin Orthod. 1995; 1 (3):139-48.

292. VIG, PS; WEINTRAUB, JA; BROWN, C; KOWALSKI, CJ. The duration of orthodontic treatment with and without extractions: a pilot study of five selected practices. Am J Orthod Dentofacial Orthop. 1990; 97 (1):4551. 
293. VIGORITO, JW. Estudo comparativo de algumas características mandibulares em maloclusões de Classe I e Classe II, divisão 1 de Angle. Rev. Fac, Odont. USP. 1973; 11 (1):75-82.

294. VOUDOURIS, JC; KUFTINEC, MM. Improved clinical use of Twin-block and Herbst as a result of radiating viscoelastic tissue forces on the condyle and fossa in treatment and long-term retention: growth relativity. Am J Orthod Dentofacial Orthop. 2000; 117 (3):247-66.

295. VOUDOURIS, JC; WOODSIDE, DG; ALTUNA, G; KUFTINEC, MM; ANGELOPOULOS, G; BOURQUE, PJ. Condyle-fossa modifications and muscle interactions during herbst treatment, part 1. New technological methods. Am J Orthod Dentofacial Orthop. 2003; 123 (6):604-13.

296. VOUDOURIS, JC; WOODSIDE, DG; ALTUNA, G; ANGELOPOULOS, G; BOURQUE, PJ; LACOUTURE, CY; KUFTINEC, MM. Condyle-fossa modifications and muscle interactions during Herbst treatment, Part 2. Results and conclusions. Am J Orthod Dentofacial Orthop. 2003; 124 (1):13-29.

297. WEHRBEIN, H; FEIFEL, H; DIEDRICH, P. Palatal implant anchorage reinforcement of posterior teeth: A prospective study. Am J Orthod Dentofacial Orthop. 1999; 116 (6):678-86.

298. WERTZ, RA. Diagnosis and treatment planning of unilateral Class II malocclusions. Angle Orthod. 1975; 45 (2):85-94.

299. WEST, KS; MCNAMARA, JA, Jr. Changes in the craniofacial complex from adolescence to midadulthood: a cephalometric study. Am J Orthod Dentofacial Orthop. 1999; 115 (5):521-32.

300. WHEELER, TT; MCGORRAY, SP; DOLCE, C; TAYLOR, MG; KING, GJ. Effectiveness of early treatment of Class II malocclusion. Am J Orthod Dentofacial Orthop. 2002; 121 (1):9-17.

301. WIESLANDER, L. Intensive treatment of severe Class II malocclusions with a headgear-Herbst appliance in the early mixed dentition. Am J Orthod. 1984; $86(1): 1-13$.

302. WIESLANDER, L. Long-term effect of treatment with the headgear-Herbst appliance in the early mixed dentition. Stability or relapse? Am J Orthod Dentofacial Orthop. 1993; 104 (4):319-29.

303. WIESLANDER, L; LAGERSTROM, L. The effect of activator treatment on class II malocclusions. Am J Orthod. 1979; 75 (1):20-6. 
304. WOODSIDE, DG. cephalometric roentgenography. In: CLARK, JW. Clinical Dentistry. New York:, Harper \& Row, 1980.

305. WOODSIDE, DG. Do functional appliances have an orthopedic effect? Am J Orthod Dentofacial Orthop. 1998; 113 (1):11-4.

306. YAMAGUCHI, K; NANDA, RS. The effects of extraction and nonextraction treatment on the mandibular position. Am $\mathbf{J}$ Orthod Dentofacial Orthop. $1991 ; 100(5): 443-52$.

307. YOKOTA, S; MURAKAMI, T; SHIMIZU, K. A growth control approach to Class II, Division 1 cases during puberty involving the simultaneous application of maxillary growth restriction and mandibular forward induction. Am J Orthod Dentofacial Orthop. 1993; 104 (3):211-23.

308. YOUNG, TM; SMITH, RJ. Effects of orthodontics on the facial profile: a comparison of changes during nonextraction and four premolar extraction treatment. Am J Orthod Dentofacial Orthop. 1993; 103 (5):452-8.

309. ZACHRISSON, BU. JCO/interviews Dr. Bjorn U. Zachrisson on excellence in finishing. Part 1. J Clin Orthod. 1986; 20 (7):460-82.

310. ZENTNER, A; PEYLO, S; BROTHAG, D. Predictive value of morphologic parameters for successful correction of Class II Division 2 malocclusion. Am J Orthod Dentofacial Orthop. 2003; 123 (3):279-85.

311. ZIERHUT, EC; JOONDEPH, DR; ARTUN, J; LITTLE, RM. Long-term profile changes associated with successfully treated extraction and nonextraction Class II Division 1 malocclusions. Angle Orthod. 2000; 70 (3):208-19. 

Apêndices 



\section{APÊNDICES}

As tabelas de A-1 até A-11 referem-se aos valores individuais de cada variável, para cada paciente, para os grupos 1, 2A e $2 \mathrm{~B}$.

TABELA A-1

\begin{tabular}{|c|c|c|c|c|c|c|}
\hline \multicolumn{2}{|c|}{ Paciente } & \multirow{2}{*}{$\begin{array}{c}\text { Gênero } \\
\mathrm{F}\end{array}$} & \multirow{2}{*}{$\begin{array}{c}\text { Tipo de } \\
\text { CI II } \\
1\end{array}$} & \multirow{2}{*}{$\begin{array}{c}\begin{array}{c}\text { Fase da } \\
\text { dentadura }\end{array} \\
\text { P }\end{array}$} & \multirow{2}{*}{ Grupo } & \multirow{2}{*}{$\begin{array}{c}\text { Idade Inicial } \\
13,5\end{array}$} \\
\hline 1. & P. B. & & & & & \\
\hline 2. & C. C. B. & $\mathrm{F}$ & 1 & $\mathrm{P}$ & 1 & 11,66 \\
\hline 3. & C. C. & $\mathrm{M}$ & 1 & $\mathrm{M}$ & 1 & 13,24 \\
\hline 4. & A. M. N. & $\mathrm{M}$ & 1 & $\mathrm{P}$ & 1 & 12,24 \\
\hline 5. & G. G. P. S. C. & $M$ & 1 & $\mathrm{P}$ & 1 & 12,24 \\
\hline 6. & L. Y. J. & $\mathrm{F}$ & 2 & $\mathrm{P}$ & 1 & 10,58 \\
\hline 7. & M. C. G. & $\mathrm{F}$ & 1 & $\mathrm{P}$ & 1 & 10,33 \\
\hline 8. & V. M. H. & $\mathrm{M}$ & 2 & $\mathrm{P}$ & 1 & 12,16 \\
\hline 9. & C. O. C. & $\mathrm{F}$ & 1 & $\mathrm{P}$ & 1 & 14,75 \\
\hline 10. & R. S. J. & $\mathrm{M}$ & 1 & $\mathrm{P}$ & 1 & 13,66 \\
\hline 11. & A. F. & $\mathrm{F}$ & 1 & $\mathrm{P}$ & 1 & 9,91 \\
\hline 12. & N. F. D. & $F$ & 1 & $\mathrm{P}$ & 1 & 12,83 \\
\hline 13. & G. P. C. & $\mathrm{F}$ & 1 & $M$ & 1 & 12,83 \\
\hline 14. & E. P. A. & $\mathrm{F}$ & 1 & $\mathrm{M}$ & 1 & 11 \\
\hline 15. & R. C. L. & $\mathrm{F}$ & 2 & $\mathrm{M}$ & 1 & 11,16 \\
\hline 16. & P. M. Y. & $\mathrm{F}$ & 1 & $\mathrm{M}$ & 1 & 10,41 \\
\hline 17. & J. L. S. & $M$ & 1 & $\mathrm{P}$ & 1 & 10,16 \\
\hline 18. & A. Z. & $\mathrm{F}$ & 1 & $\mathrm{P}$ & 1 & 11,33 \\
\hline 19. & M. A. M. & $\mathrm{M}$ & 1 & $\mathrm{P}$ & 1 & 12,83 \\
\hline 20. & D. H. F. S. & $\mathrm{M}$ & 1 & $\mathrm{M}$ & 1 & 11,91 \\
\hline 21. & P. R. M. & $\mathrm{M}$ & 1 & $\mathrm{P}$ & 1 & 14,33 \\
\hline 22. & L. C. C. & $M$ & 1 & $\mathrm{P}$ & 1 & 12,24 \\
\hline 23. & F.S. S. & $M$ & 1 & $\mathrm{P}$ & 1 & 13,24 \\
\hline 24. & H.T. S. & $\mathrm{M}$ & 1 & $\mathrm{P}$ & 1 & 13,24 \\
\hline 25. & H. O. M. P. & $M$ & 1 & $\mathrm{P}$ & 1 & 13,08 \\
\hline 26. & D. O. M. L. & $\mathrm{M}$ & 2 & $\mathrm{P}$ & 1 & 16,66 \\
\hline 27. & R. L. M. & $M$ & 1 & $\mathrm{M}$ & 1 & 11,66 \\
\hline 28. & J. P. P. L.i & $\mathrm{M}$ & 1 & $\mathrm{M}$ & 1 & 8,58 \\
\hline 29. & M. M. O. & $M$ & 1 & $\mathrm{P}$ & 1 & 16 \\
\hline 30. & N. S. R. & $\mathrm{F}$ & 2 & $\mathrm{M}$ & 1 & 11,58 \\
\hline 31. & O. P. G. & $M$ & 1 & $\mathrm{M}$ & 1 & 12,16 \\
\hline 32. & T. L. T. & $M$ & 1 & $\mathrm{P}$ & 1 & 16,24 \\
\hline 33. & J. G. M. & $\mathrm{F}$ & 1 & $\mathrm{P}$ & 1 & 15 \\
\hline 34. & A. A. A. & $M$ & 1 & $\mathrm{M}$ & 1 & 12,83 \\
\hline 35. & V. S. M. & $\mathrm{M}$ & 1 & $\mathrm{P}$ & 1 & 15,66 \\
\hline 36. & B. M. P. & $\mathrm{F}$ & 1 & $\mathrm{P}$ & 1 & 13,08 \\
\hline 37. & T. F. G. & $\mathrm{F}$ & 2 & $\mathrm{M}$ & 1 & 12 \\
\hline 38. & M. L. S. T. & $\mathrm{F}$ & 1 & $\mathrm{P}$ & 1 & 11,58 \\
\hline 39. & T. M. F. & $M$ & 1 & $\mathrm{P}$ & 1 & 11,08 \\
\hline 40. & H. J. S. & $M$ & 1 & $\mathrm{M}$ & 1 & 10 \\
\hline 41. & F. L. G. V. S. & $\mathrm{M}$ & 1 & $\mathrm{P}$ & 1 & 11,75 \\
\hline 42. & L. A. G. & $\mathrm{F}$ & 1 & $\mathrm{P}$ & 1 & 12,41 \\
\hline 43. & C. O. F. & $\mathrm{F}$ & 2 & $\mathrm{P}$ & 1 & 11,08 \\
\hline 44. & J. R. S. Jr. & $\mathrm{M}$ & 1 & $\mathrm{P}$ & 1 & 16,16 \\
\hline
\end{tabular}


TABELA A-2

\begin{tabular}{|c|c|c|c|c|c|c|}
\hline 45. & H. D. G. & $\mathrm{F}$ & 1 & $P$ & 1 & 11,83 \\
\hline 46. & V. H. M. C. & $M$ & 1 & $\mathrm{P}$ & 1 & 12,83 \\
\hline 47. & A. Ap. P. & $\mathrm{F}$ & 1 & $\bar{M}$ & 1 & 11 \\
\hline 48. & A. A. T. & $\mathrm{F}$ & 2 & $M$ & 1 & 11,66 \\
\hline 49. & A. M. V. & $M$ & 1 & $P$ & 1 & 13,83 \\
\hline 50. & A. C. P.S. & $\mathrm{F}$ & 1 & $P$ & 1 & 13,08 \\
\hline 51. & A. B. S. & $\mathrm{F}$ & 1 & $M$ & 1 & 11,24 \\
\hline 52. & A. M. A. & $\mathrm{F}$ & 2 & $\mathrm{P}$ & 1 & 13,33 \\
\hline 53. & A. C. J. & $\mathrm{F}$ & 1 & $M$ & 1 & 11 \\
\hline 54. & A. C. T. & $\mathrm{F}$ & 1 & $P$ & 1 & 11,08 \\
\hline 55. & A. P. Z. G. & $\mathrm{F}$ & 1 & $\mathrm{P}$ & 1 & 13,24 \\
\hline 56. & A.P. R. & $\mathrm{F}$ & 1 & $M$ & 1 & 8,83 \\
\hline 57. & A. A. B. & $\bar{M}$ & 1 & $P$ & 1 & 11,66 \\
\hline 58. & A. S. A. & $M$ & 2 & $P$ & 1 & 13,75 \\
\hline 59. & A. A. & $\mathrm{F}$ & 1 & $M$ & 1 & 12,83 \\
\hline 60. & A. L. C. & $\mathrm{F}$ & 1 & $M$ & 1 & 11,33 \\
\hline 61. & A. M. & $\mathrm{F}$ & 1 & $\mathrm{P}$ & 1 & 11 \\
\hline 62. & B. L. M. & $\mathrm{F}$ & 1 & $M$ & 1 & 10,16 \\
\hline 63. & C. R. G. & $\mathrm{F}$ & 2 & $\mathrm{P}$ & 1 & 11,16 \\
\hline 64. & C. C. B. F. & $\mathrm{F}$ & 1 & $P$ & 1 & 13,66 \\
\hline 65. & C. O, R. & $\mathrm{F}$ & 1 & $P$ & 1 & 11,75 \\
\hline 66. & C. L. C. Jr. & $M$ & 1 & $\mathrm{P}$ & 1 & 12,33 \\
\hline 67. & C. A. B. F. & $M$ & 1 & $M$ & 1 & 12,24 \\
\hline 68. & D. B. R. & $\mathrm{F}$ & 1 & $\mathrm{M}$ & 1 & 10,5 \\
\hline 69. & D. L. & $\mathrm{F}$ & 1 & $P$ & 1 & 13,5 \\
\hline 70. & D. F.D. & $\mathrm{F}$ & 2 & $\mathrm{P}$ & 1 & 12,33 \\
\hline 71. & D. M. H. & $\mathrm{F}$ & 1 & M & 1 & 12,58 \\
\hline 72. & E. G. C. & $\mathrm{M}$ & 1 & $M$ & 1 & 11,75 \\
\hline 73. & E. R. N. & $M$ & 1 & $P$ & 1 & 13,5 \\
\hline 74. & E. S. S. L. & $\mathrm{F}$ & 1 & $P$ & 1 & 11,5 \\
\hline 75. & E. N. M. O. & $\mathrm{F}$ & 1 & $P$ & 1 & 11,66 \\
\hline 76. & E. A. B. & $M$ & 1 & $\mathrm{P}$ & 1 & 14 \\
\hline 77. & F. B. B. & $M$ & 1 & $M$ & 1 & 12,5 \\
\hline 78. & F.S. & $\mathrm{F}$ & 1 & $M$ & 1 & 13,16 \\
\hline 79. & F.S.P. & $\mathrm{F}$ & 1 & $P$ & 1 & 12,83 \\
\hline 80. & F. M. R. & $M$ & 2 & $M$ & 1 & 10,08 \\
\hline 81. & F. C. A. M. B. & $\mathrm{F}$ & 1 & M & 1 & 10,33 \\
\hline 82. & F. G. & $F$ & 1 & $P$ & 1 & 11,91 \\
\hline 83. & G. P. A. & $F$ & 1 & $P$ & 1 & 11,83 \\
\hline 84. & G. E. V. & $\mathrm{F}$ & 2 & $\mathrm{P}$ & 1 & 13 \\
\hline 85. & G. O. M. & M & 1 & $P$ & 1 & 14,08 \\
\hline 86. & H. C. & M & 1 & $M$ & 1 & 10,58 \\
\hline 87. & I. C. M. F. & $\mathrm{F}$ & 2 & $P$ & 1 & 12,41 \\
\hline 88. & I.I A. & $\mathrm{M}$ & 1 & $P$ & 1 & 12,24 \\
\hline 89. & I. M. O. & $\mathrm{F}$ & 1 & $\mathrm{P}$ & 1 & 13,5 \\
\hline 90. & J. G. B. B.P. & M & 1 & M & 1 & 12,41 \\
\hline 91. & J. L. M. J. & $M$ & 1 & $M$ & 1 & 10,5 \\
\hline 92. & J. M. C. & $M$ & 1 & $\mathrm{M}$ & 1 & 10,41 \\
\hline 93. & J. X. M. Jr. & M & 1 & $M$ & 1 & 12,24 \\
\hline 94. & J. L. G. F. & M & 1 & $P$ & 1 & 13,16 \\
\hline 95. & J. Ap. M. & $\mathrm{F}$ & 1 & $\mathrm{P}$ & 1 & 13 \\
\hline 96. & J.C.F. & $\mathrm{F}$ & 2 & $\mathrm{P}$ & 1 & 11,91 \\
\hline 97. & J.G. F. & $\mathrm{F}$ & 1 & $M$ & 1 & 10,08 \\
\hline
\end{tabular}


TABELA A-3

\begin{tabular}{|c|c|c|c|c|c|c|}
\hline 98. & J. G. C. & M & 1 & $P$ & 1 & 15,33 \\
\hline 99. & K.Y.S. & $\mathrm{F}$ & 1 & $P$ & 1 & 12,24 \\
\hline 100. & K. G. C. & $\mathrm{F}$ & 1 & $M$ & 1 & 11,58 \\
\hline 101. & K. R. L. & $F$ & 2 & $P$ & 1 & 12,24 \\
\hline 102. & L. C. S. & $M$ & 1 & $P$ & 1 & 11,75 \\
\hline 103. & L. G. G. & M & 1 & M & 1 & 11,42 \\
\hline 104. & L. R. & $\mathrm{F}$ & 1 & $M$ & 1 & 12,83 \\
\hline 105. & L. F. M. B. & $M$ & 1 & $\mathrm{P}$ & 1 & 12,5 \\
\hline 106. & M. P. & $M$ & 1 & $P$ & 1 & 14,58 \\
\hline 107. & M. T. Y. & M & 1 & $P$ & 1 & 12,08 \\
\hline 108. & M. C. M. H. & $F$ & 1 & $P$ & 1 & 12,5 \\
\hline 109. & M. G. S. Z. & $\mathrm{F}$ & 1 & $\mathrm{P}$ & 1 & 11,58 \\
\hline 110. & M. A. M. & $\mathrm{F}$ & 1 & $M$ & 1 & 12,33 \\
\hline 111. & M. P. B. & $\mathrm{F}$ & 1 & $P$ & 1 & 11,58 \\
\hline 112. & M. G. & $\mathrm{F}$ & 2 & $M$ & 1 & 12,24 \\
\hline 113. & M. C. P. & $\mathrm{F}$ & 2 & $M$ & 1 & 14,5 \\
\hline 114. & M.P. O. & $\mathrm{F}$ & 1 & M & 1 & 11,83 \\
\hline 115. & M. C.P. & $\bar{M}$ & 1 & $M$ & 1 & 13,66 \\
\hline 116. & N. D. C. & $F$ & 1 & $M$ & 1 & 10,75 \\
\hline 117. & P. C. M. & $\mathrm{F}$ & 2 & $P$ & 1 & 12,08 \\
\hline 118. & P. G. G. & $\mathrm{F}$ & 1 & $P$ & 1 & 12,16 \\
\hline 119. & P.R. C. & $\mathrm{F}$ & 1 & M & 1 & 12,66 \\
\hline 120. & P. E. D. C. & $\bar{M}$ & 1 & $M$ & 1 & 12,5 \\
\hline 121. & P.C. & $\mathrm{F}$ & 1 & $\mathrm{P}$ & 1 & 11,24 \\
\hline 122. & R. O. & $M$ & 1 & $P$ & 1 & 12,91 \\
\hline 123. & R. D. R. C. & $M$ & 1 & M & 1 & 10,58 \\
\hline 124. & R. N. B. & $M$ & 1 & $\mathrm{P}$ & 1 & 12,5 \\
\hline 125. & R. C.P. & $\bar{M}$ & 1 & $M$ & 1 & 11,08 \\
\hline 126. & R. A. F. & $\bar{M}$ & 1 & $M$ & 1 & 13 \\
\hline 127. & R. H.S. & M & 1 & M & 1 & 13,83 \\
\hline 128. & R. L. M. & M & 1 & $P$ & 1 & 14,08 \\
\hline 129. & R. G. P. & $\mathrm{M}$ & 1 & $M$ & 1 & 11,16 \\
\hline 130. & R. B. F.i & $M$ & 2 & $M$ & 1 & 13,16 \\
\hline 131. & S. M. & $\mathrm{F}$ & 1 & $M$ & 1 & 11,75 \\
\hline 132. & S. L. S. & M & 1 & $M$ & 1 & 11,24 \\
\hline 133. & S. N. E. & $\mathrm{F}$ & 1 & $P$ & 1 & 9,91 \\
\hline 134. & S. S. & $\mathrm{F}$ & 1 & M & 1 & 9,5 \\
\hline 135. & T. A. A. & $\bar{M}$ & 1 & $P$ & 1 & 16,5 \\
\hline 136. & T. C. L. & $\mathrm{F}$ & 2 & $P$ & 1 & 10,41 \\
\hline 137. & T.P. R. C. & $F$ & 1 & $P$ & 1 & 13,16 \\
\hline 138. & T. A. O. & $M$ & 1 & $M$ & 1 & 10,41 \\
\hline 139. & V.J.C. & $M$ & 1 & $P$ & 1 & 12,83 \\
\hline 140. & V. C.P. & $F$ & 1 & $P$ & 1 & 13 \\
\hline 141. & V.P. & $\mathrm{F}$ & 2 & $M$ & 1 & 11,08 \\
\hline 142. & V. G. S. A. & $M$ & 1 & M & 1 & 10,91 \\
\hline 143. & V. G. D. & M & 1 & $M$ & 1 & 12,24 \\
\hline 144. & Y. G. S. & $\mathrm{F}$ & 1 & $M$ & 1 & 14,83 \\
\hline 145. & A. S. S. & $\mathrm{F}$ & 1 & $P$ & $2 \mathrm{~A}$ & 11,83 \\
\hline 146. & M. A. C. & M & 1 & $P$ & $2 \mathrm{~A}$ & 12,33 \\
\hline 147. & E. M. & $\mathrm{F}$ & 1 & $P$ & $2 \mathrm{~A}$ & 12,5 \\
\hline 148. & J.C.P. & $\mathrm{M}$ & 1 & $P$ & $2 \mathrm{~A}$ & 13,58 \\
\hline 149. & J. A. A. C. & $M$ & 1 & $P$ & $2 \mathrm{~A}$ & 15,66 \\
\hline 150. & C. A.S.S. & $F$ & 1 & $P$ & $2 \mathrm{~A}$ & 13,58 \\
\hline
\end{tabular}


TABELA A-4

\begin{tabular}{|c|c|c|c|c|c|c|}
\hline 151. & E. W. L. & M & 1 & $\mathrm{P}$ & $2 \mathrm{~A}$ & 13,83 \\
\hline 152. & B. S. & $\mathrm{F}$ & 2 & $P$ & $2 \mathrm{~A}$ & 11,75 \\
\hline 153. & L. B. P. & $\mathrm{F}$ & 1 & $P$ & $2 A$ & 11,08 \\
\hline 154. & F. M. A. & $M$ & 1 & $P$ & $2 A$ & 12,83 \\
\hline 155. & V. L. U. V. & M & 1 & $\mathrm{P}$ & $2 A$ & 13,66 \\
\hline 156. & L. G. R. I. & M & 1 & M & $2 \mathrm{~A}$ & 12,24 \\
\hline 157. & R. H. C. & $M$ & 1 & $\mathrm{P}$ & $2 A$ & 12,5 \\
\hline 158. & C. L.S.S.O. & $M$ & 1 & $M$ & $2 A$ & 11,58 \\
\hline 159. & W. M. L. & $M$ & 1 & $M$ & $2 A$ & 10,08 \\
\hline 160. & T. C. F.. & M & 2 & M & $2 \mathrm{~A}$ & 11,41 \\
\hline 161. & C. L. C. & $\mathrm{F}$ & 1 & $P$ & $2 A$ & 11,66 \\
\hline 162. & V. V. & $M$ & 1 & $M$ & $2 A$ & 14,24 \\
\hline 163. & F. C. S. C. & $\mathrm{F}$ & 1 & $\mathrm{M}$ & $2 A$ & 8,91 \\
\hline 164. & L. F. M. & $\mathrm{F}$ & 1 & $\mathrm{P}$ & $2 A$ & 14,33 \\
\hline 165. & J.R. M. & $M$ & 1 & $M$ & $2 A$ & 13,08 \\
\hline 166. & L. E. R. G. & $M$ & 1 & $P$ & $2 A$ & 15,24 \\
\hline 167. & R. F. L. & $\mathrm{M}$ & 1 & $\mathrm{P}$ & $2 A$ & 13,75 \\
\hline 168. & J.S.G. & $\mathrm{F}$ & 1 & $P$ & $2 A$ & 14 \\
\hline 169. & Y.H. C. G. & $\mathrm{F}$ & 1 & $M$ & $2 A$ & 10,33 \\
\hline 170. & L. G. A. A. & M & 1 & $\mathrm{P}$ & $2 A$ & 13,83 \\
\hline 171. & V. R. C. & M & 1 & $\mathrm{P}$ & $2 A$ & 13,41 \\
\hline 172. & W. L. G. & $M$ & 1 & $M$ & $2 A$ & 11,24 \\
\hline 173. & F.C.B. & $M$ & 2 & $\mathrm{P}$ & $2 A$ & 13,66 \\
\hline 174. & M. M. R. & $\mathrm{M}$ & 2 & $\mathrm{M}$ & $2 \mathrm{~A}$ & 11,66 \\
\hline 175. & M. C. F. & $\mathrm{F}$ & 1 & M & $2 A$ & 11,33 \\
\hline 176. & A. H. P. C. & $\mathrm{F}$ & 1 & M & $2 A$ & 11,24 \\
\hline 177. & A. F. G. & $F$ & 1 & $\mathrm{P}$ & $2 A$ & 12,5 \\
\hline 178 & A. R. C. M. & $\mathrm{F}$ & 1 & $\mathrm{M}$ & $2 A$ & 12,24 \\
\hline 179 & A. S. M. & M & 1 & $P$ & $2 A$ & 12,24 \\
\hline 180 & A. S. A. & M & 1 & $M$ & $2 A$ & 12 \\
\hline 181 & A. C. G. & $\mathrm{F}$ & 1 & $P$ & $2 A$ & 12,91 \\
\hline 182 & A. C. L. K. & $\mathrm{F}$ & 2 & $\mathrm{P}$ & $2 A$ & 13,33 \\
\hline 183 & A. C. F. C. & $\mathrm{F}$ & 1 & $P$ & $2 A$ & 12,83 \\
\hline 184 & A. C. T. S. & $\mathrm{F}$ & 1 & $\bar{M}$ & $2 A$ & 11,16 \\
\hline 185 & A. F. B. & $\mathrm{F}$ & 1 & M & $2 \mathrm{~A}$ & 13,24 \\
\hline 186 & A. L. O. G. & $\mathrm{F}$ & 1 & $\mathrm{P}$ & $2 \mathrm{~A}$ & 11,41 \\
\hline 187. & A. L. T. B. D. & $\mathrm{F}$ & 2 & $\mathrm{M}$ & $2 \mathrm{~A}$ & 11,08 \\
\hline 188 & A. M. M. S. & $\mathrm{F}$ & 1 & $\mathrm{M}$ & $2 A$ & 12,08 \\
\hline 189 & A.P. E. & $\mathrm{F}$ & 1 & $\bar{M}$ & $2 A$ & 12,58 \\
\hline 190 & A. M. P. C. & $\mathrm{F}$ & 1 & $\mathrm{P}$ & $2 \mathrm{~A}$ & 13,24 \\
\hline 191 & A. F. C. T. & M & 1 & $\mathrm{M}$ & $2 A$ & 12,08 \\
\hline 192 & B. C. S. & M & 1 & $\mathrm{P}$ & $2 A$ & 13,5 \\
\hline 193 & B.F.S. & $\mathrm{M}$ & 1 & $\mathrm{M}$ & $2 A$ & 10,41 \\
\hline 194 & C. A. R. & $\mathrm{F}$ & 1 & $\mathrm{M}$ & $2 A$ & 11,75 \\
\hline 195 & C. L. B. & $\mathrm{F}$ & 1 & $\mathrm{M}$ & $2 A$ & 10,16 \\
\hline 196 & C. R.S. & $\mathrm{F}$ & 1 & $\mathrm{P}$ & $2 \mathrm{~A}$ & 11,91 \\
\hline 197. & C. A.P. & $\mathrm{M}$ & 1 & $\mathrm{P}$ & $2 \mathrm{~A}$ & 10,83 \\
\hline 198 & C. C. U. & $\mathrm{M}$ & 1 & $\mathrm{P}$ & $2 A$ & 13,08 \\
\hline 199 & C. G. S. C. A. & M & 1 & $\mathrm{P}$ & $2 A$ & 13,33 \\
\hline 200 & C. S. C. & $\mathrm{F}$ & 2 & M & $2 A$ & 13 \\
\hline 201. & D. M. O. & $\mathrm{F}$ & 1 & $\mathrm{P}$ & $2 \mathrm{~A}$ & 11,5 \\
\hline 202 & D. C. J. & $\mathrm{M}$ & 1 & $\mathrm{P}$ & $2 A$ & 16,33 \\
\hline 203 & D. A. M. & $\mathrm{M}$ & 1 & $M$ & $2 A$ & 12,83 \\
\hline
\end{tabular}


TABELA A-5

\begin{tabular}{|c|c|c|c|c|c|c|}
\hline 204. & D. D. J. & M & 1 & $\mathrm{P}$ & $2 \mathrm{~A}$ & 14,58 \\
\hline 205. & E. Ap. S. & $\mathrm{F}$ & 2 & $\mathrm{P}$ & $2 \mathrm{~A}$ & 11,24 \\
\hline 206. & E. N.S. & $\bar{M}$ & 1 & $P$ & $2 \mathrm{~A}$ & 14,33 \\
\hline 207. & F. A. R. & $\mathrm{F}$ & 1 & $P$ & $2 \mathrm{~A}$ & 12,24 \\
\hline 208. & F. C. & $\mathrm{M}$ & 1 & M & $2 \mathrm{~A}$ & 11,42 \\
\hline 209. & F. P. A. & $\mathrm{F}$ & 1 & M & $2 \mathrm{~A}$ & 10,58 \\
\hline 210. & G. A. G. & M & 1 & M & $2 \mathrm{~A}$ & 13,08 \\
\hline 211. & H. C. & $M$ & 2 & $M$ & $2 \mathrm{~A}$ & 12,75 \\
\hline 212. & H.S. & $\mathrm{M}$ & 1 & $\mathrm{M}$ & $2 \mathrm{~A}$ & 12,24 \\
\hline 213. & J.S. F. & $\mathrm{F}$ & 1 & $P$ & $2 \mathrm{~A}$ & 12,24 \\
\hline 214. & J.P. M. & M & 1 & M & $2 \mathrm{~A}$ & 13,08 \\
\hline 215. & J.E. F.P. & $\mathrm{M}$ & 1 & M & $2 \mathrm{~A}$ & 11 \\
\hline 216. & J.D.F. V. & $F$ & 2 & $P$ & $2 \mathrm{~A}$ & 14,41 \\
\hline 217. & L. R. S. V. & $\bar{M}$ & 1 & $\mathrm{M}$ & $2 \mathrm{~A}$ & 15,08 \\
\hline 218. & L. I. & $\mathrm{F}$ & 1 & $P$ & $2 \mathrm{~A}$ & 12,5 \\
\hline 219. & L. F. G. C. & M & 1 & M & $2 \mathrm{~A}$ & 11,16 \\
\hline 220. & L. G. B. & $\mathrm{M}$ & 1 & $M$ & $2 \mathrm{~A}$ & 12,91 \\
\hline 221. & M. S. C. & $\bar{M}$ & 1 & $M$ & $2 \mathrm{~A}$ & 10,91 \\
\hline 222. & M. F. & $\mathrm{F}$ & 1 & $P$ & $2 \mathrm{~A}$ & 12,33 \\
\hline 223. & M. G. S. & $\mathrm{F}$ & 2 & $\mathrm{P}$ & $2 \mathrm{~A}$ & 12,5 \\
\hline 224. & M. A. C. & $\mathrm{M}$ & 1 & M & $2 \mathrm{~A}$ & 8,5 \\
\hline 225. & M. M. L. & M & 1 & $P$ & $2 \mathrm{~A}$ & 12 \\
\hline 226. & M. T. & $M$ & 1 & $P$ & $2 \mathrm{~A}$ & 11,91 \\
\hline 227. & M. C. R. & $\mathrm{F}$ & 1 & $M$ & $2 \mathrm{~A}$ & 10,91 \\
\hline 228. & M. S. & $\mathrm{F}$ & 1 & M & $2 \mathrm{~A}$ & 11,16 \\
\hline 229. & M. B. & $\mathrm{F}$ & 1 & $M$ & $2 \mathrm{~A}$ & 10,83 \\
\hline 230. & M. E. D. & $\mathrm{F}$ & 1 & $P$ & $2 \mathrm{~A}$ & 13,24 \\
\hline 231. & N. C. & $\mathrm{F}$ & 1 & $\mathrm{P}$ & $2 \mathrm{~A}$ & 14,5 \\
\hline 232. & N. H. G. & $\mathrm{F}$ & 1 & $M$ & $2 \mathrm{~A}$ & 9,41 \\
\hline 233. & N. M. G. & $\mathrm{F}$ & 1 & $M$ & $2 \mathrm{~A}$ & 9,91 \\
\hline 234. & N. H. C. G. & $F$ & 1 & M & $2 \mathrm{~A}$ & 10,33 \\
\hline 235. & P. C. G. & $\mathrm{F}$ & 2 & $M$ & $2 \mathrm{~A}$ & 12,24 \\
\hline 236. & P.F.P. & $\mathrm{F}$ & 1 & $M$ & $2 \mathrm{~A}$ & 7,91 \\
\hline 237. & P. M. C. & $F$ & 1 & $M$ & $2 \mathrm{~A}$ & 10,5 \\
\hline 238. & R. M. M. & $M$ & 1 & $P$ & $2 \mathrm{~A}$ & 13,33 \\
\hline 239. & R. G. S. G. & $\mathrm{F}$ & 1 & M & $2 \mathrm{~A}$ & 12,16 \\
\hline 240. & R. L. & $F$ & 1 & M & $2 \mathrm{~A}$ & 11,17 \\
\hline 241. & R. N. P. F. & $M$ & 1 & $M$ & $2 \mathrm{~A}$ & 12,24 \\
\hline 242. & R.P.F. & $\mathrm{M}$ & 1 & M & $2 \mathrm{~A}$ & 11,24 \\
\hline 243. & T. M. B. & $\mathrm{F}$ & 1 & $\mathrm{P}$ & $2 \mathrm{~A}$ & 13 \\
\hline 244. & T. L. & $\mathrm{F}$ & 2 & $M$ & $2 \mathrm{~A}$ & 11 \\
\hline 245. & T. Z.N. & $\mathrm{F}$ & 2 & $P$ & $2 \mathrm{~A}$ & 13 \\
\hline 246. & T. H. A. C. & $F$ & 1 & $\mathrm{M}$ & $2 \mathrm{~A}$ & 11,33 \\
\hline 247. & T. B. T. & $F$ & 1 & $\mathrm{M}$ & $2 \mathrm{~A}$ & 11 \\
\hline 248. & V.X. A. & $F$ & 2 & M & $2 \mathrm{~A}$ & 11,41 \\
\hline 249. & V. Ap. S. & $F$ & 1 & $P$ & $2 \mathrm{~A}$ & 14,16 \\
\hline 250. & V.X. A. & $\mathrm{F}$ & 1 & M & $2 \mathrm{~A}$ & 13 \\
\hline 251. & W. O. P. P & $\bar{M}$ & 1 & $M$ & $2 \mathrm{~A}$ & 12,58 \\
\hline 252. & A. B. J. & M & 1 & $P$ & $2 \mathrm{~B}$ & 15,00 \\
\hline 253. & A. L. & $\mathrm{F}$ & 1 & $P$ & $2 \mathrm{~B}$ & 14,58 \\
\hline 254. & A. L. R. D. & $F$ & 1 & $P$ & $2 \mathrm{~B}$ & 11,42 \\
\hline 255. & A. M. & $F$ & 2 & M & $2 \mathrm{~B}$ & 11,92 \\
\hline
\end{tabular}


TABELA A-6

\begin{tabular}{ll|l|l|l|l|l}
\hline 256. & A. P. L. & $\mathrm{F}$ & 1 & $\mathrm{P}$ & 2B & 12,83 \\
\hline 257. & B. L. L. & $\mathrm{M}$ & 2 & $\mathrm{P}$ & $2 \mathrm{~B}$ & 11,58 \\
\hline 258. & B. T. & $\mathrm{M}$ & 1 & $\mathrm{P}$ & $2 \mathrm{~B}$ & 14,08 \\
\hline 259. & C. S. Z. & $\mathrm{F}$ & 2 & $\mathrm{M}$ & $2 \mathrm{~B}$ & 11,33 \\
\hline 260. & D. B. P. & $\mathrm{M}$ & 1 & $\mathrm{P}$ & $2 \mathrm{~B}$ & 15,17 \\
\hline 261. & E. B. & $\mathrm{F}$ & 1 & $\mathrm{M}$ & $2 \mathrm{~B}$ & 11,50 \\
\hline 262. & J. T. J. & $\mathrm{M}$ & 2 & $\mathrm{P}$ & $2 \mathrm{~B}$ & 14,00 \\
\hline 263. & L. A. S. & $\mathrm{M}$ & 2 & $\mathrm{P}$ & $2 \mathrm{~B}$ & 17,25 \\
\hline 264. & L. E. B. & $\mathrm{M}$ & 1 & $\mathrm{P}$ & $2 \mathrm{~B}$ & 12,33 \\
\hline 265. & L. F. R. & $\mathrm{F}$ & 1 & $\mathrm{P}$ & $2 \mathrm{~B}$ & 11,92 \\
\hline 266. & L. F. T. & $\mathrm{F}$ & 1 & $\mathrm{P}$ & $2 \mathrm{~B}$ & 13,08 \\
\hline 267. & M. E. A. P. & $\mathrm{F}$ & 1 & $\mathrm{P}$ & $2 \mathrm{~B}$ & 21,50 \\
\hline 268. & M. R. B. V. & $\mathrm{M}$ & 1 & $\mathrm{P}$ & $2 \mathrm{~B}$ & 11,50 \\
\hline 269. & M. V. R. S. & $\mathrm{M}$ & 1 & $\mathrm{P}$ & $2 \mathrm{~B}$ & 12,75 \\
\hline 270. & M. F. Z. C. & $\mathrm{F}$ & 1 & $\mathrm{P}$ & $2 \mathrm{~B}$ & 12,67 \\
\hline 271. & P. C. P. & $\mathrm{F}$ & 2 & $\mathrm{P}$ & $2 \mathrm{~B}$ & 13,33 \\
\hline 272. & R. H. C. & $\mathrm{M}$ & 1 & $\mathrm{M}$ & $2 \mathrm{~B}$ & 10,67 \\
\hline 273. & R. L. P. & $\mathrm{F}$ & 1 & $\mathrm{M}$ & $2 \mathrm{~B}$ & 11,42 \\
\hline 274. & R.P.. & $\mathrm{M}$ & 2 & $\mathrm{P}$ & $2 \mathrm{~B}$ & 12,00 \\
\hline 275. & R. R. M. & $\mathrm{M}$ & 1 & $\mathrm{M}$ & $2 \mathrm{~B}$ & 9,42 \\
\hline 276. & R. R. & $\mathrm{F}$ & 1 & $\mathrm{P}$ & $2 \mathrm{~B}$ & 12,42 \\
\hline 277. & Y. T. C. & $\mathrm{M}$ & 1 & $\mathrm{P}$ & $2 \mathrm{~B}$ & 12,17 \\
\hline
\end{tabular}


TABELA A-7

\begin{tabular}{|c|c|c|c|c|c|c|c|}
\hline \multicolumn{2}{|c|}{ Paciente } & IPTI & IPTF & DIFIPT & PCIPT & IETIPT & TTRAT \\
\hline 1. & P. B. & 9,22 & 1,77 & 7,45 & 80,80 & 3,51 & 23 \\
\hline 2. & C. C. B. & 5,22 & 0 & 5,22 & 100 & 4,54 & 22 \\
\hline 3. & C. C. & 4,82 & 1,77 & 3,05 & 63,27 & 2,63 & 24 \\
\hline 4. & A. M. N. & 6,92 & 3,07 & 3,85 & 55,63 & 2,92 & 19 \\
\hline 5. & G. G.P. S. C. & 6,32 & 0 & 6,32 & 100 & 2,85 & 35 \\
\hline 6. & L. Y.J. & 4,92 & 1,77 & 3,15 & 64,02 & 2,56 & 25 \\
\hline 7. & M. C. G. & 6,82 & 1,77 & 5,05 & 74,04 & 1,42 & 52 \\
\hline 8. & V. M. H. & 7,72 & 0,27 & 7,45 & 96,50 & 3,44 & 28 \\
\hline 9. & C. O. C. & 3,82 & 1,77 & 2,05 & 53,66 & 3,15 & 17 \\
\hline 10. & R. S. J. & 11,42 & 0 & 11,42 & 100 & 3,03 & 33 \\
\hline 11. & A. F. & 3,32 & 0,27 & 3,05 & 91,86 & 5,10 & 18 \\
\hline 12. & N. F. D. & 5,82 & 0 & 5,82 & 100 & 3,12 & 32 \\
\hline 13. & G. P. C. & 7,02 & 0,27 & 6,75 & 96,15 & 4,18 & 23 \\
\hline 14. & E. P. A. & 10,02 & 0,57 & 9,45 & 94,31 & 2,94 & 32 \\
\hline 15. & R. C. L. & 10,32 & 0,27 & 10,05 & 97,38 & 3,14 & 31 \\
\hline 16. & P. M. Y. & 5,42 & 1,77 & 3,65 & 67,34 & 3,74 & 18 \\
\hline 17. & J. L. S. & 9,32 & 0 & 9,32 & 100 & 2,94 & 34 \\
\hline 18. & A. Z. & 7,12 & 1,5 & 5,62 & 78,93 & 3,58 & 22 \\
\hline 19. & M. A. M. & 6,42 & 0,27 & 6,15 & 95,79 & 5,32 & 18 \\
\hline 20. & D. H. F.S. & 7,82 & 0,27 & 7,55 & 96,54 & 1,50 & 64 \\
\hline 21. & P. R. M. & 9,22 & 1,5 & 7,72 & 83,73 & 3,80 & 22 \\
\hline 22. & L. C. C. & 4,32 & 3,62 & 0,7 & 16,20 & 0,57 & 28 \\
\hline 23. & F.S.S. & 4,92 & 0,27 & 4,65 & 94,51 & 3,63 & 26 \\
\hline 24. & H.T.S. & 11,02 & 4,02 & 7 & 63,52 & 1,76 & 36 \\
\hline 25. & H. O. M. P. & 11,82 & 1,8 & 10,02 & 84,77 & 1,92 & 44 \\
\hline 26. & D. O. M. L. & 9,92 & 1,77 & 8,15 & 82,15 & 3,91 & 21 \\
\hline 27. & R. L. M. & 6,82 & 1,5 & 5,32 & 78,00 & 2,16 & 36 \\
\hline 28. & J.P.P. L.i & 12,72 & 2,57 & 10,15 & 79,79 & 2,41 & 33 \\
\hline 29. & M. M. O. & 6,12 & 3,8 & 2,32 & 37,90 & 3,15 & 12 \\
\hline 30. & N. S. R. & 7,92 & 1,77 & 6,15 & 77,65 & 3,10 & 25 \\
\hline 31. & O.P. G. & 8,52 & 0 & 8,52 & 100 & 3,22 & 31 \\
\hline 32. & T. L. T. & 10,82 & 0 & 10,82 & 100 & 5 & 20 \\
\hline 33. & J. G. M. & 7,12 & 1,77 & 5,35 & 75,14 & 5,00 & 15 \\
\hline 34. & A. A. A. & 10,92 & 1,77 & 9,15 & 83,79 & 3,99 & 21 \\
\hline 35. & V.S. M. & 9,52 & 3,62 & 5,9 & 61,97 & 2,69 & 23 \\
\hline 36. & B. M.P. & 8,52 & 1,77 & 6,75 & 79,22 & 7,20 & 11 \\
\hline 37. & T.F. G. & 5,12 & 0 & 5,12 & 100 & 2 & 50 \\
\hline 38. & M. L. S. T. & 9,52 & 0,27 & 9,25 & 97,16 & 6,47 & 15 \\
\hline 39. & T. M. F. & 5,82 & 3,4 & 2,42 & 41,58 & 1,12 & 37 \\
\hline 40. & H. J.S. & 10,02 & 2,2 & 7,82 & 78,04 & 3,71 & 21 \\
\hline 41. & F. L. G. V.S. & 8,12 & 1,37 & 6,75 & 83,12 & 5,19 & 16 \\
\hline 42. & L. A. G. & 8,52 & 0,67 & 7,85 & 92,13 & 4,18 & 22 \\
\hline 43. & C. O. F. & 7,32 & 2,9 & 4,42 & 60,38 & 2,87 & 21 \\
\hline & J. R. S. Jr. & 8,82 & 2,2 & 6,62 & 75,05 & 2,68 & 28 \\
\hline 45. & H. D. G. & 8,52 & 2,2 & 6,32 & 74,17 & 4,94 & 15 \\
\hline 46. & V. H. M. C. & 8,52 & 0,67 & 7,85 & 92,13 & 5,11 & 18 \\
\hline 47. & A. Ap. P. & 7,32 & 1,77 & 5,55 & 75,81 & 3,99 & 19 \\
\hline 48. & A. A. T. & 5,82 & 2,9 & 2,92 & 50,17 & 2,28 & 22 \\
\hline & A. M. V. & 9,32 & 1,77 & 7,55 & 81,00 & 4,76 & 17 \\
\hline & A. C.P.S. & 7,52 & 0,27 & 7,25 & 96,40 & 5,67 & 17 \\
\hline 51. & A. B. S. & 5,02 & 0,27 & 4,75 & 94,62 & 2,95 & 32 \\
\hline
\end{tabular}


TABELA A-8

\begin{tabular}{|c|c|c|c|c|c|c|c|}
\hline 52. & A. M. A. & 7,52 & 0,27 & 7,25 & 96,40 & 2,92 & 33 \\
\hline 53. & A. C. J. & 3,92 & 0,27 & 3,65 & 93,11 & 3,10 & 30 \\
\hline 54. & A. C. T. & 7,72 & 1,5 & 6,22 & 80,56 & 5,37 & 15 \\
\hline 55. & A. P. Z. G. & 9,52 & 2,17 & 7,35 & 77,20 & 3,35 & 23 \\
\hline 56. & A. P. R. & 5,42 & 0,57 & 4,85 & 89,48 & 1,90 & 47 \\
\hline 57. & A. A. B. & 6,62 & 0 & 6,62 & 100 & 5,26 & 19 \\
\hline 58. & A. S. A. & 10,42 & 0,67 & 9,75 & 93,57 & 4,67 & 20 \\
\hline 59. & A. A. & 10,32 & 1,5 & 8,82 & 85,46 & 4,27 & 20 \\
\hline 60. & A. L. C. & 6,42 & 2,9 & 3,52 & 54,82 & 1,76 & 31 \\
\hline 61. & A. M. & 8,12 & 1,77 & 6,35 & 78,20 & 4,88 & 16 \\
\hline 62. & B. L. M. & 9,22 & 2,1 & 7,12 & 77,22 & 3,21 & 24 \\
\hline 63. & C. R. G. & 7,52 & 0 & 7,52 & 100 & 4,34 & 23 \\
\hline 64. & C. C. B. F. & 4,52 & 1,5 & 3,02 & 66,81 & 2,47 & 27 \\
\hline 65. & C. O, R. & 10,22 & 0,57 & 9,65 & 94,42 & 5,55 & 17 \\
\hline 66. & C. L. C. Jr. & 8,52 & 2,72 & 5,8 & 68,07 & 2,26 & 30 \\
\hline 67. & C. A. B. F. & 6,72 & 0,27 & 6,45 & 95,98 & 3,09 & 31 \\
\hline 68. & D. B. R. & 10,02 & 2,6 & 7,42 & 74,05 & 3,52 & 21 \\
\hline 69. & D. L. & 9,02 & 0 & 9,02 & 100 & 5 & 20 \\
\hline 70. & D. F. D. & 9,52 & 0,27 & 9,25 & 97,16 & 2,94 & 33 \\
\hline 71. & D. M. H. & 6,42 & 0,27 & 6,15 & 95,79 & 2,90 & 33 \\
\hline 72. & E. G. C. & 7,92 & 0,27 & 7,65 & 96,59 & 6,43 & 15 \\
\hline 73. & E. R. N. & 8,82 & 1,5 & 7,32 & 82,99 & 5,18 & 16 \\
\hline 74. & E. S. S. L. & 9,22 & 0,27 & 8,95 & 97,07 & 4,85 & 20 \\
\hline 75. & E. N. M. O. & 8,52 & 0 & 8,52 & 100 & 4,54 & 22 \\
\hline 76. & E. A. B. & 7,22 & 0 & 7,22 & 100 & 2,5 & 40 \\
\hline 77. & F. B. B. & 13,22 & 0 & 13,22 & 100 & 6,25 & 16 \\
\hline 78. & F.S. & 12,42 & 0 & 12,42 & 100 & 2,38 & 42 \\
\hline 79. & F.S.P. & 6,32 & 0,27 & 6,05 & 95,72 & 2,90 & 33 \\
\hline 80. & F.M. R. & 8,42 & 1,77 & 6,65 & 78,97 & 2,63 & 30 \\
\hline 81. & F. C. A. M. B. & 5,42 & 3,3 & 2,12 & 39,11 & 1,95 & 20 \\
\hline 82. & F. G. & 4,92 & 1,5 & 3,42 & 69,51 & 3,15 & 22 \\
\hline 83. & G. P. A. & 10,02 & 0 & 10,02 & 100 & 7,69 & 13 \\
\hline 84. & G. E. V. & 4,52 & 1,5 & 3,02 & 66,81 & 4,77 & 14 \\
\hline 85. & G. O. M. & 7,72 & 1,77 & 5,95 & 77,07 & 4,28 & 18 \\
\hline 86. & H. C. & 4,52 & 0 & 4,52 & 100 & 4 & 25 \\
\hline 87. & I. C. M. F. & 5,52 & 1,5 & 4,02 & 72,82 & 3,64 & 20 \\
\hline 88. & I.I A. & 7,62 & 3,12 & 4,5 & 59,05 & 2,10 & 28 \\
\hline 89. & I. M. O. & 5,32 & 2,6 & 2,72 & 51,12 & 2,69 & 19 \\
\hline 90. & J. G. B. B.P. & 12,09 & 0 & 12,09 & 100 & 5,55 & 18 \\
\hline 91. & J. L. M. J. & 10,32 & 0 & 10,32 & 100 & 7,69 & 13 \\
\hline 92. & J. M. C. & 8,12 & 3,4 & 4,72 & 58,12 & 2,76 & 21 \\
\hline 93. & J. X. M. Jr. & 5,42 & 0 & 5,42 & 100 & 1,40 & 71 \\
\hline 94. & J. L. G. F. & 6,42 & 1,77 & 4,65 & 72,42 & 3,81 & 19 \\
\hline 95. & J. Ap. M. & 7,62 & 0 & 7,62 & 100 & 4,76 & 21 \\
\hline 96. & J. C. F. & 8,72 & 0,27 & 8,45 & 96,90 & 2,15 & 45 \\
\hline 97. & J. G. F. & 9,02 & 0 & 9,02 & 100 & 3,57 & 28 \\
\hline 98. & J. G. C. & 6,42 & 1,5 & 4,92 & 76,63 & 3,06 & 25 \\
\hline 99. & K. Y.S. & 4,92 & 1,5 & 3,42 & 69,51 & 3,31 & 21 \\
\hline 100. & K. G. C. & 8,52 & 0,27 & 8,25 & 96,83 & 7,44 & 13 \\
\hline 101. & K. R. L. & 8,62 & 0 & 8,62 & 100 & 3,12 & 32 \\
\hline 102. & L. C. S. & 5,82 & 1,5 & 4,32 & 74,22 & 5,30 & 14 \\
\hline 103. & L. G. G. & 4,02 & 0,27 & 3,75 & 93,28 & 4,44 & 21 \\
\hline
\end{tabular}


TABELA A-9

\begin{tabular}{|c|c|c|c|c|c|c|c|}
\hline 104. & L. R. & 5,42 & 1,5 & 3,92 & 72,32 & 2,33 & 31 \\
\hline 105. & L. F. M. B. & 7,62 & 0,27 & 7,35 & 96,45 & 3,57 & 27 \\
\hline 106. & M. P. & 6,92 & 0,27 & 6,65 & 96,09 & 4,36 & 22 \\
\hline 107. & M. T. Y. & 9,52 & 1,77 & 7,75 & 81,40 & 4,52 & 18 \\
\hline 108. & M. C. M. H. & 7,72 & 1,5 & 6,22 & 80,56 & 6,19 & 13 \\
\hline 109. & M. G. S. Z. & 11,22 & 0 & 11,22 & 100 & 5 & 20 \\
\hline 110. & M. A. M. & 10,32 & 0 & 10,32 & 100 & 2,70 & 37 \\
\hline 111. & M. P. B. & 6,72 & 2,6 & 4,12 & 61,30 & 7,66 & 8 \\
\hline 112. & M. G. & 6,32 & 2,6 & 3,72 & 58,86 & 2,67 & 22 \\
\hline 113. & M. C.P. & 8,62 & 0,27 & 8,35 & 96,86 & 4,211 & 23 \\
\hline 114. & M. P. O. & 12,32 & 0 & 12,32 & 100 & 3,70 & 27 \\
\hline 115. & M. C.P. & 11,02 & 0 & 11,02 & 100 & 4,76 & 21 \\
\hline 116. & N. D. C. & 7,32 & 2,17 & 5,15 & 70,35 & 1,95 & 36 \\
\hline 117. & P. C. M. & 5,12 & 0 & 5,12 & 100 & 4,34 & 23 \\
\hline 118. & P. G. G. & 11,02 & 0,67 & 10,35 & 93,92 & 4,47 & 21 \\
\hline 119. & P. R. C. & 6,72 & 2,17 & 4,55 & 67,70 & 3,76 & 18 \\
\hline 120. & P. E. D. C. & 5,82 & 3,4 & 2,42 & 41,58 & 2,07 & 20 \\
\hline 121. & P.C. & 14.92 & 1,5 & 13,42 & 89,94 & 4,28 & 21 \\
\hline 122. & R. 0 . & 8,52 & 0 & 8,52 & 100 & 6,25 & 16 \\
\hline 123. & R. D. R. C. & 5,42 & 1,5 & 3,92 & 72,32 & 2,26 & 32 \\
\hline 124. & R. N. B. & 9,52 & 0 & 9,52 & 100 & 4 & 25 \\
\hline 125. & R. C.P. & 6,32 & 2,17 & 4,15 & 65,66 & 3,86 & 17 \\
\hline 126. & R. A. F. & 12,22 & 1,37 & 10,85 & 88,78 & 3,69 & 24 \\
\hline 127. & R. H. S. & 8,52 & 0,87 & 7,65 & 89,78 & 5,98 & 15 \\
\hline 128. & R. L. M. & 10,32 & 1,5 & 8,82 & 85,46 & 3,16 & 27 \\
\hline 129. & R. G. P. & 7,22 & 1,77 & 5,45 & 75,48 & 1,64 & 46 \\
\hline 130. & R. B. F.i & 6,92 & 2,87 & 4,05 & 58,52 & 1,14 & 51 \\
\hline 131. & S.M. & 7,52 & 0 & 7,52 & 100 & 2,94 & 34 \\
\hline 132. & S. L. S. & 6,42 & 2,72 & 3,7 & 57,63 & 3,60 & 16 \\
\hline 133. & S. N. E. & 7,62 & 1,5 & 6,12 & 80,31 & 3,49 & 23 \\
\hline 134. & S. S. & 5,22 & 1,37 & 3,85 & 73,75 & 2,73 & 27 \\
\hline 135. & T. A. A. & 7,72 & 2,17 & 5,55 & 71,89 & 3,12 & 23 \\
\hline 136. & T. C. L. & 6,32 & 1,5 & 4,82 & 76,26 & 4,01 & 19 \\
\hline 137. & T.P. R. C. & 10,42 & 0 & 10,42 & 100 & 2,63 & 38 \\
\hline 138. & T. A. O. & 9,52 & 1,77 & 7,75 & 81,40 & 3,13 & 26 \\
\hline 139. & V. J. C. & 7,32 & 2,6 & 4,72 & 64,48 & 3,58 & 18 \\
\hline 140. & V.C.P. & 6,92 & 1,5 & 5,42 & 78,32 & 4,12 & 19 \\
\hline 141. & V.P. & 9,92 & 1,77 & 8,15 & 82,15 & 3,91 & 21 \\
\hline 142. & V. G. S. A. & 4,32 & 1,77 & 2,55 & 59,02 & 1,96 & 30 \\
\hline 143. & V. G. D. & 10,32 & 2,6 & 7,72 & 74,80 & 2,99 & 25 \\
\hline 144. & Y. G. S. & 8,52 & 0 & 8,52 & 100 & 5,55 & 18 \\
\hline 145. & A. S. S. & 7,17 & 0,27 & 6,9 & 96,23 & 8,74 & 11 \\
\hline 146. & M. A. C. & 8,57 & 0 & 8,57 & 100 & 5,55 & 18 \\
\hline 147. & E. M. & 8,67 & 1,8 & 6,87 & 79,23 & 2,47 & 32 \\
\hline 148. & J. C. P. & 14,07 & 2,92 & 11,15 & 79,24 & 2,40 & 33 \\
\hline 149. & J. A. A. C. & 8,27 & 1,5 & 6,77 & 81,86 & 3,03 & 27 \\
\hline 150. & C. A.S.S. & 8,07 & 0,27 & 7,8 & 96,65 & 4,02 & 24 \\
\hline 151. & E. W. L. & 12,37 & 4,3 & 8,07 & 65,23 & 2,83 & 23 \\
\hline 152. & B. S. & 8,67 & 0,67 & 8 & 92,27 & 2,14 & 43 \\
\hline 153. & L. B. P. & 9,67 & 1,77 & 7,9 & 81,69 & 3,71 & 22 \\
\hline 154. & F. M. A. & 7,17 & 0,27 & 6,9 & 96,23 & 4,37 & 22 \\
\hline
\end{tabular}


TABELA A-10

\begin{tabular}{|c|c|c|c|c|c|c|c|}
\hline 155. & V. L. U. V. & 12,47 & 0,57 & 11,9 & 95,42 & 2,21 & 43 \\
\hline 156. & L. G. R. I. & 7,37 & 1,5 & 5,87 & 79,64 & 2,15 & 37 \\
\hline 157. & R. H. C. & 8,07 & 0,27 & 7,8 & 96,65 & 3,57 & 27 \\
\hline 158. & C. L. S. S. O. & 8,37 & 0 & 8,37 & 100 & 2,43 & 41 \\
\hline 159. & W. M. L. & 8,87 & 0,67 & 8,2 & 92,44 & 2,00 & 46 \\
\hline 160. & T. C. F.. & 8,97 & 0,27 & 8,7 & 96,98 & 2,42 & 40 \\
\hline 161. & C. L. C. & 7,67 & 0 & 7,67 & 100 & 4 & 25 \\
\hline 162. & V.V. & 9,37 & 0,27 & 9,1 & 97,11 & 3,34 & 29 \\
\hline 163. & F. C.S. C. & 5,82 & 0 & 5,82 & 100 & 2,27 & 44 \\
\hline 164. & L. F. M. & 7,17 & 4,95 & 2,22 & 30,96 & 1,23 & 25 \\
\hline 165. & J.R. M. & 8,87 & 1,77 & 7,1 & 80,04 & 6,15 & 13 \\
\hline 166. & L. E. R. G. & 8,27 & 1,77 & 6,5 & 78,59 & 4,62 & 17 \\
\hline 167. & R. F. L. & 9,37 & 0,97 & 8,4 & 89,64 & 5,27 & 17 \\
\hline 168. & J. S. G. & 6,97 & 1,77 & 5,2 & 74,60 & 3,39 & 22 \\
\hline 169. & Y.H. C. G. & 9,37 & 4,77 & 4,6 & 49,09 & 0,87 & 56 \\
\hline 170. & L. G. A. A. & 9,67 & 4,6 & 5,07 & 52,43 & 1,94 & 27 \\
\hline 171. & V.R. C. & 9,87 & 0 & 9,87 & 100 & 3,33 & 30 \\
\hline 172. & W. L. G. & 8,07 & 3,67 & 4,4 & 54,52 & 1,29 & 42 \\
\hline 173. & F. C. B. & 7,87 & 1,77 & 6,1 & 77,50 & 3,69 & 21 \\
\hline 174. & M. M. R. & 9,47 & 2,6 & 6,87 & 72,54 & 2,79 & 26 \\
\hline 175. & M. C. F. & 9,07 & 0,27 & 8,8 & 97,02 & 8,82 & 11 \\
\hline 176. & A. H. P. C. & 7,17 & 0,27 & 6,9 & 96,23 & 3,43 & 28 \\
\hline 177. & A. F. G. & 8,97 & 0,27 & 8,7 & 96,98 & 4,40 & 22 \\
\hline 178. & A. R. C. M. & 7,97 & 0 & 7,97 & 100 & 2,77 & 36 \\
\hline 179. & A. S. M. & 8,37 & 4,3 & 4,07 & 48,62 & 2,55 & 19 \\
\hline 180. & A. S. A. & 10,37 & 1,37 & 9 & 86,78 & 4,33 & 20 \\
\hline 181. & A. C. G. & 7,77 & 4,02 & 3,75 & 48,26 & 1,50 & 32 \\
\hline 182. & A. C. L. K. & 7,77 & 4,2 & 3,57 & 45,94 & 1,70 & 27 \\
\hline 183. & A. C. F. C. & 6,57 & 0 & 6,57 & 100 & 3,03 & 33 \\
\hline 184. & A. C. T. S. & 9,77 & 0 & 9,77 & 100 & 2,32 & 43 \\
\hline 185. & A. F. B. & 9,67 & 4,62 & 5,05 & 52,22 & 1,74 & 30 \\
\hline 186. & A. L. O. G. & 9,07 & 0,27 & 8,8 & 97,02 & 4,62 & 21 \\
\hline 187. & A. L. T. B. D. & 7,77 & 0,27 & 7,5 & 96,52 & 3,44 & 28 \\
\hline 188. & A. M. M. S. & 12,07 & 6,47 & 5,6 & 46,39 & 1,54 & 30 \\
\hline 189. & A.P. E. & 10,57 & 1,77 & 8,8 & 83,25 & 2,68 & 31 \\
\hline 190. & A. M. P. C. & 7,67 & 5,15 & 2,52 & 32,85 & 1,05 & 31 \\
\hline 191. & A. F. C. T. & 9,67 & 3,4 & 6,27 & 64,83 & 3,41 & 19 \\
\hline 192. & B. C.S. & 8,77 & 3,92 & 4,85 & 55,30 & 2,30 & 24 \\
\hline 193. & B.F.S. & 7,37 & 1,77 & 5,6 & 75,98 & 1,18 & 64 \\
\hline 194. & C. A. R. & 8,77 & 0,27 & 8,5 & 96,92 & 1,76 & 55 \\
\hline 195. & C. L. B. & 10,17 & 2,6 & 7,57 & 74,43 & 1,61 & 46 \\
\hline 196. & C. R. S. & 9,07 & 0,27 & 8,8 & 97,02 & 2,31 & 42 \\
\hline 197. & C. A. P. & 8,37 & 3,62 & 4,75 & 56,75 & 1,83 & 31 \\
\hline 198. & C. C.U. & 8,27 & 0,27 & 8 & 96,73 & 5,69 & 17 \\
\hline 199. & C. G. S. C. A. & 10,77 & 2,6 & 8,17 & 75,85 & 1,80 & 42 \\
\hline 200. & C. S. C. & 9,27 & 2,9 & 6,37 & 68,71 & 4,04 & 17 \\
\hline 201. & D. M. O. & 9,87 & 1,5 & 8,37 & 84,80 & 4,03 & 21 \\
\hline 202. & D. C.J. & 8,37 & 7,07 & 1,3 & 15,53 & 0,77 & 20 \\
\hline 203. & D. A. M. & 11,07 & 1,77 & 9,3 & 84,01 & 2,89 & 29 \\
\hline 204. & D. D. J. & 10,17 & 4,02 & 6,15 & 60,47 & 1,88 & 32 \\
\hline 205. & E. Ap. S. & 8,77 & 4,42 & 4,35 & 49,60 & 1,90 & 26 \\
\hline 206. & E. N. S. & 8,27 & 3,62 & 4,65 & 56,22 & 1,12 & 50 \\
\hline
\end{tabular}


TABELA A-11

\begin{tabular}{|c|c|c|c|c|c|c|c|}
\hline & F.A.R. & 12,07 & 5,42 & 6,65 & 55,09 & 2,20 & 25 \\
\hline 208. & F. C. & 9,07 & 0,27 & 8,8 & 97,02 & 3,46 & 28 \\
\hline 209. & F. P. A. & 9,37 & 1,5 & 7,87 & 83,99 & 2,15 & 39 \\
\hline 210. & G. A. G. & 8,07 & 2,72 & 5,35 & 66,29 & 3,01 & 22 \\
\hline 211. & H. C. & 7,07 & 0 & 7,07 & 100 & 2,63 & 38 \\
\hline 212. & H. S. & 9,67 & 0,27 & 9,4 & 97,20 & 2,62 & 37 \\
\hline 213. & J.S.F. & 8,67 & 1,77 & 6,9 & 79,58 & 2,84 & 28 \\
\hline 214. & J.P.M. & 12,07 & 0 & 12,07 & 100 & 4,34 & 23 \\
\hline 215. & J.E. F.P. & 7,87 & 1,37 & 6,5 & 82,59 & 2,84 & 29 \\
\hline 216. & J.D. F. V. & 9,67 & 1,37 & 8,3 & 85,83 & 6,60 & 13 \\
\hline 217. & L. R. S. V. & 8,97 & 1,77 & 7,2 & 80,26 & 1,70 & 47 \\
\hline 218. & L. I. & 10,27 & 1,5 & 8,77 & 85,39 & 4,26 & 20 \\
\hline 219. & L. F. G. C. & 8,97 & 1,37 & 7,6 & 84,72 & 3,02 & 28 \\
\hline 220. & L. G. B. & 9,67 & 0 & 9,67 & 100 & 3,57 & 28 \\
\hline 221. & M. S. C. & 9,92 & 0,27 & 9,65 & 97,27 & 3,74 & 26 \\
\hline 222. & M. F. & 10,37 & 0,67 & 9,7 & 93,53 & 1,70 & 55 \\
\hline 223. & M. G. S. & 9,07 & 6,67 & 2,4 & 26,46 & 0,63 & 42 \\
\hline 224. & M. A. C. & 11,47 & 1,5 & 9,97 & 86,92 & 2,22 & 39 \\
\hline 225. & M. M. L. & 9,67 & 0 & 9,67 & 100 & 2,38 & 42 \\
\hline 226. & M. T. & 8,17 & 4,6 & 3,57 & 43,69 & 1,14 & 38 \\
\hline 227. & M. C. R. & 10,07 & 0 & 10,07 & 100 & 3,44 & 29 \\
\hline 228. & M. S. & 8,57 & 3,4 & 5,17 & 60,32 & 2,41 & 25 \\
\hline 229. & M. B. & 8,37 & 0 & 8,37 & 100 & 3,84 & 26 \\
\hline 230. & M. E. D. & 9,37 & 0,27 & 9,1 & 97,11 & 3,13 & 31 \\
\hline 231. & N. C. & 7,97 & 0,67 & 7,3 & 91,59 & 4,36 & 21 \\
\hline 232. & N. H. G. & 6,77 & 1,8 & 4,97 & 73,41 & 1,63 & 45 \\
\hline 233. & N. M. G. & 12,27 & 1,5 & 10,77 & 87,77 & 1,82 & 48 \\
\hline 234. & N. H. C. G. & 5,97 & 0 & 5,97 & 100 & 2,56 & 39 \\
\hline 235. & P. C. G. & 10,27 & 2,72 & 7,55 & 73,51 & 2,82 & 26 \\
\hline 236. & P.F.P. & 5,37 & 1,77 & 3,6 & 67,03 & 1,26 & 53 \\
\hline 237. & P. M. C. & 9,37 & 0,27 & 9,1 & 97,11 & 2,77 & 35 \\
\hline 238. & R. M. M. & 11,07 & 2,6 & 8,47 & 76,51 & 2,94 & 26 \\
\hline 239. & R. G. S. G & 8,67 & 1,8 & 6,87 & 79,23 & 3,96 & 20 \\
\hline 240. & R. L. & 9,97 & 2,6 & 7,37 & 73,92 & 2,84 & 26 \\
\hline 241. & R. N. P. F. & 8,17 & 3,4 & 4,77 & 58,38 & 1,26 & 46 \\
\hline 242. & R.P.F. & 10,67 & 3,27 & 7,4 & 69,35 & 2,56 & 27 \\
\hline 243. & T. M. B. & 7,17 & 1,5 & 5,67 & 79,07 & 3,04 & 26 \\
\hline 244. & T. L. & 8,87 & 1,77 & 7,1 & 80,04 & 2,50 & 32 \\
\hline 245. & T. Z. N. & 9,07 & 2,7 & 6,37 & 70,23 & 1,80 & 39 \\
\hline 246. & T. H. A. C. & 9,67 & 0,67 & 9 & 93,07 & 4,23 & 22 \\
\hline 247. & T. B. T. & 7,87 & 0 & 7,87 & 100 & 2,32 & 43 \\
\hline 248. & V.X. A. & 8,07 & 0,27 & 7,8 & 96,65 & 3,71 & 26 \\
\hline 249. & V. Ap. S. & 10,57 & 0 & 10,57 & 100 & 1,85 & 54 \\
\hline 250. & V.X. A. & 8,07 & 1,5 & 6,57 & 81,41 & 4,52 & 18 \\
\hline 251. & W. O.P.P & 8,37 & 5,55 & 2,82 & 33,69 & 0,68 & 49 \\
\hline
\end{tabular}


This document was created with Win2PDF available at http://www.win2pdf.com.

The unregistered version of Win2PDF is for evaluation or non-commercial use only.

This page will not be added after purchasing Win2PDF. 